\title{
Reviving Tocqueville's America: The Rehnquist Court's Jurisprudence of Social Discovery
}

\author{
John O. McGinnis $\dagger$
}

\section{TABLE of Contents}

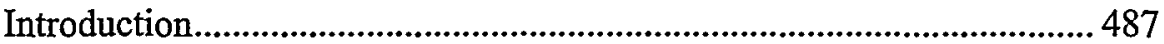

I. The Reorientation of the Supreme Court's Jurisprudence..................498

II. Federalism: Reconstituting a Spontaneous Order of Governance.... 507

A. Federalism's Contribution to Private Ordering and Its

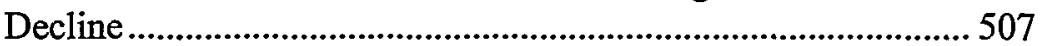

B. The Rehnquist Court's Revival of Federalism........................... 511

C. The Uncertain Shape of Federalism's Revival ...........................516

D. The Future of Federalism as a Discovery Machine ..................... 522

III. Reviving Mediating Institutions Through Freedom of

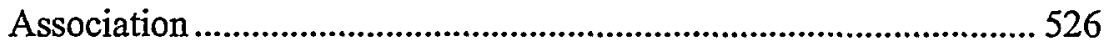

A. Expanding the Right of Expressive Association....................... 530

B. The Congruence of Political and Civil Associational Rights ..... 538

C. Permitting Government Aid to Civil Associations on a

Neutral Basis..................................................................... 540

IV. Creating ConstitutionaI Space for Competition from Religiously

Backed Norms ............................................................................... 543

A. Moving to Government Neutrality as the Touchstone of

Establishment Clause Jurisprudence.

B. Protecting Religious Expression of Associations through the

Free Speech Clause

Copyright (C) 2002 California Law Review, Inc. California Law Review, Inc. (CLR) is a California nonprofit corporation. CLR and the authors are solely responsible for the content of their publications.

$\dagger$ Professor of Law, Benjamin N. Cardozo School of Law, Yeshiva University. I am grateful to Chief Judge J. Harvie Wilkinson III and the Fourth Circuit at whose conference the idea for this Article arose. I am also grateful to Akhil Amar, Erwin Chemerinsky, A.E. Howard, and John Jeffries, my stimulating interlocutors on that occasion. Thanks to Bob Bennett, Neal Devins, Shari Diamond, Charles Fried, Michael Herz, Kyron Huigens, Andrew Koppelman, Nelson Lund, Michael McConnell, Mark Movsesian, Martin Redish, Michel Rosenfeld, David Rudenstine, and Richard Weisberg for their thoughts on earlier drafts and to David Golove for useful discussions. I am also grateful to colloquia at Boston University, Cardozo, Hofstra, Northwestern, and William and Mary law schools, where I received helpful comments. 
C. The Free Exercise Clause and the Appropriate Neutrality Between the Secular and the Religiously Backed Norms. 555

V. Reinforcing the Jury as a Mediating Institution

VI. The Framework of Fundamental Rights Jurisprudence and the Construction of a Constitution of Spontaneous Order 565

Conclusion 571 


\title{
Reviving Tocqueville's America: The Rehnquist Court's Jurisprudence of Social Discovery
}

\author{
John O. McGinnis
}

This Article offers a retrospective on the Rehnquist Court. It argues that the Rehnquist Court has been pursuing a coherent jurisprudence that invigorates decentralization and the private ordering of social norms that Alexis De Tocqueville celebrated in Democracy in America as being the essence of the social order generated by our original Constitution. In four disparate areas-federalism, freedom of association, the religion clauses, and the balance of power between juries and judges-the Court is helping sustain a civil order that bubbles up from state governments or from citizens voluntarily gathered together or randomly selected.

The Article is the first to seek to do for the Rehnquist Court what John Hart Ely did for the Warren Court in Deinocracy and Distrust-ground the full range of its jurisprudence in a coherent theory of governance. Ely saw the Warren Court as an attempt to constitute a functioning majoritarian democracy and improve its outputs. But in our era political theories, such as public choice, have shown that the disproportionate influence of special interest groups and the inattention of the general citizenry can prevent centralized democracy from measuring majority will and producing good social norms. In contrast, the kind of decentralized civic order described by Tocqueville engages the citizen and restrains special interests through competition, whether the competition is among different states or among different associations. The Rehnquist Court jurisprudence is designed to sustain this more decentralized system of order by protecting the autonomy of decentralized "discovery machines" for social norms, like mediating institutions and state government, from the encroachments of more centralized power.

\section{INTRODUCTION}

The jurisprudence of the Rehnquist Court, now fifteen years old, still awaits a coherent explication. While many commentators have addressed 
and criticized specific doctrines and cases, ${ }^{1}$ there has been no sustained effort to find the key ideas that underlie the full range of this Court's decision making. ${ }^{2}$ Such a theory would link the important changes the Rehnquist Court has been making in disparate areas of constitutional law from federalism to the First Amendment to criminal procedure. Understanding the unity of the Rehnquist Court's jurisprudence, whether one approves of it or not, ${ }^{3}$ is a crucial step in evaluating its contribution to our era.

In his justly celebrated book, Democracy and Distrust, ${ }^{4}$ John Hart Ely provided this service for the Warren Court by distilling a coherent theory of constitutional governance from its jurisprudence. ${ }^{5}$ Ely understood the Warren Court's jurisprudence as focused on reinforcing democracy, thus permitting government to do the work of social reform. ${ }^{6} \mathrm{He}$ argued that most constitutional rights provisions were designed to reinforce democratic representation or correct defects in the representative process rather than to protect a sphere of individual autonomy. ${ }^{7}$ For instance, Ely reasoned that the Warren Court shaped some constitutional rights, like the First

1. For a variety of journal articles critiquing specific areas of law in relation to the Rehnquist Court, see Erwin Chemerinsky, The Hypocrisy of Alden v. Maine; Judicial Review, Sovereign Immunity, and the Rehnquist Court, 33 LoY. L.A. L. REv. 1283 (2000) (critiquing the sovereign immunity decisions of the Rehnquist Court); Thomas R. Hensley \& G.R. Jarrod Tudor, An Analysis of the Rehnquist Court's Establishment Clause Jurisprudence: A New Marriage of Legal and Social Science Approaches, 1999 L. REv. MICH. ST. U. DET. C.L. 869 (analyzing the Rehnquist Court's Establishment Clause jurisprudence in terms of legal methodology and social science); Frank R. Parker, The Damaging Consequences of the Rehnquist Court's Commitment to Color-Blindness Versus Racial Justice, 45 AM. U. L. REv. 763 (1996) (analyzing the Rehnquist Court's Equal Protection Clause decisions in the mid-1990s and the impact of color-blind limitations on government in areas of education, minority business development, and voting reform); Mark A. Racanelli, Reversals: Privacy and the Rehnquist Court, 81 GEo. L.J. 443 (1992) (analyzing the Rehnquist Court's eageruess to reverse precedent, especially in the area of privacy).

2. To my knowledge, only one essay attempts to discover a comprehensive social theory behind the Rehnquist Court's decisions. See Rebecca L. Brown, Formal Neutrality in the Warren and Rehnquist Courts: Illusions of Similarity, 50 VAND. L. REv. 487 (1997). Professor Brown suggests that the Rehnquist Court is characterized by "political liberalism" that sees the state as neutral among competing values, whereas the Warren Court was characterized by "comprehensive liberalism" that believes the state should advance a substantive aspect of the good. Id. at 489-91. Even Profcssor Brown, however, applies this conceptual framework only to two areas of Rehnquist Court jurisprudence: racial equality and free speech. Id. at 487.

3. My purpose in this Article is not to offer the last word in defense of the Rehnquist Court's jurisprudence, although I have some sympathy for it. Instead, the Article's principal purpose is to show the coherence and substantiality of the Rehnquist Court's jurisprudence across a variety of doctrines. Of course, in showing its coherence and substantiality I necessarily suggest that the Rehnquist Court's jurisprudence has greater plausibility than many have thought, even if it cannot command the assent of all.

4. John Hart Ely, Democracy and Distrust (1980).

5. Id. Professor Ely's book was widely regarded as the most important book of constitutional theory of his generation. Sce, e.g., Michael J. Klarman, The Puzzling Resistance to Political Process Theory, 77 VA. L. Rev. 747, 747 (1991) (commenting that Democracy aND Distrust is "the most important contribution to political theory of the past generation").

6. ELY, supra note 4, at 181 (summarizing his theory as reinforcing democratic representation).

7. Id. at 101-02. 
Amendment, to protect inputs into democracy so that reform would be based on the best information possible. ${ }^{8}$ Ely contended that democracy was the key to understanding the Warren Court's construction of the Fourteenth Amendment, because the Warren Court used that amendment to improve the outputs of democracy by reducing majority reliance on stereotypes. ${ }^{9}$

This Article attempts to begin for the Rehnquist Court what Ely achieved for the Warren Court. ${ }^{10}$ The Rehnquist Court is moving toward an encompassing jurisprudence, just as the Warren Court did. In contrast, however, to the Warren Court's jurisprudence of empowering and perfecting democracy, particularly at the national level, the Rehnquist Court's jurisprudence is one of decentralization and private ordering of social norms. ${ }^{11}$ Like most jurisprudential movements, this one is neither complete nor fully articulate. Moreover, precedents from the Warren and Burger Courts, which preferred to generate social norms based on a more topdown vision of civic order generated by national democracy and by their own formulation of fundamental rights, constrain the Rehnquist Court's jurisprudence. Nevertheless, particularly in its recent cases that represent the culmination of trends over the previous decade, the Rehnquist Court is beginning to reconstitute its jurisprudence as a whole to infuse more elements of spontaneous and decentralized ordermg into our political system. ${ }^{12}$ This shift coincides with the growing perception that spontaneous

8. Id. at 105-34 (discussing the manner in which the First Amendment should be interpreted to aid democratic governance by "clearing the channels of political change").

9. Id. at 155-70 (discussing the manner im which the Fourteenth Amendment was interpreted to prevent legislative reliance on stereotypes).

10. I use the term "Rehnquist Court" as a heuristic device, just as Ely used the term "Warren Court." In speaking about the Warren Court, Ely did not purport to show that Chief Justice Earl Warren or any member of the Court consciously conceived of their decisions in terms of Ely's theory nor do I make such a claim about Chief Justice Rehnquist or menbers of his Court. Some members of the Warren Court dissented from the decisions Ely used to support his theory. Likewise, some members of the Rehnquist Court dissented from the decisions discussed here, although it is interesting to note that they are not always the same members. My view is that ultimately a Court is greater than the sum of its members and captures through shifting majorities some aspects of the spirit of its age.

11. Decentralization calls for public goods and services to be produced by the smallest jurisdiction that can do so efficiently. Thus, under decentralization, states are a forum for governance preferred over the federal government, absent externalities or spillovers among the states that require national regulation. As we shall see, the Warren Court was not concerned about protecting state autonomy against the decisions of the national government. See infra notes 62-64 and accompanying text.

12. By "spontaneous order," I am referring to Friedrich Hayek's concept of order created by "the decentralized processes in which countless [voluntary] interactions between ordinary individuals produced a set of results that were pleasing, but which could not be obtained by the command of any centralized political order." Richard A. Epstein, Hayekian Socialism, 58 MD. L. REv. 271, 275-76 (1999); see also 1 F.A. HAYeK, LAw, Legislation, AND LiberTy: Rules IN ORDer 39 (1982) (introducing concept of spontaneous order). The decentralization provided by federalism, to use the term of Hayek's own cousin, Ludwig Wittgenstein, has a family resemblance to "spontaneous order" because federalism creates an order through many decisions of state government that could not have been obtained by command of the federal government alone. Just as spontaneous order requires the rule of law to enforce the voluntary interaction of individuals, see Epstein, supra, at 276, federalism 
ordering mechanisms, like the market, enjoy substantial advantages over centralized governance. The Rehnquist Court is tending toward this goal through reviving federalism, ${ }^{13}$ protecting and facilitating rights of civil and religious association, ${ }^{14}$ and empowering juries at the expense of judges. ${ }^{15}$

The Rehnquist Court's jurisprudence reflects a more skeptical view of centralized democracy in an era in which there is more elite skepticism about the prospects of nationally mandated social reform than existed in the eras of the New Deal and the Great Society. Modern political science has suggested that mass national democracy often produces legislation that neither reflects majority will nor is efficient, since special interests dominate legislators while most citizens are rationally ignorant of the salient political issues. ${ }^{16}$ Hence, the Rehnquist Court is rediscovering the provisions of the Constitution that create alternative forums for norm creation by empowering institutions such as local governments and civil associations that engage the citizenry and restrain special interests. Such institutions decentralize the development of social norms and subject these norms to more rigorous forms of competition than centralized governance. Sustaining these structures requires a jurisprudence completely different from that of the Warren Court. If many of the Warren Court's decisions are best understood as perfecting centralized democracy, the Rehnquist Court should be understood as protecting the conditions of spontaneous order so that norms can be discovered through competition, whether that competition occurs among states or private institutions.

This view of constitutionalism restores a degree of the Constitution's original meaning, because the Framers shared the Rehnquist Court's contemporary concern with restraining special interests ("factions," in the language of the Framers). ${ }^{17}$ They were also concerned about protecting the beneficent norms emerging from civic society from the encroachment of government. For instance, James Wilson warned against sacrificing the primacy of civil society on the "idol of government."18 Because the

requires the nation state to keep its subdivisions at peace and sustain a free trade zone among those subdivisions. For further discussion of the requisites of federalism see infra notes 101-15 and accompanying text.

13. See infra Part II.

14. See infra Parts III and IV.

15. See infra Part V.

16. For definitions and discussions of rational ignorance and the porver of special interest groups in politics, see infra notes 74-81 and accompanying text.

17. The most famous discussion of the danger of factions is found in The Federalist 10. See THE FEDERALIST No. 10, at 45-51 (James Madison) (Clinton Rossiter ed., 1961) (suggesting that the essential problem of republican government was the tendency of factions to form and pursue their own objectives at the expense of the public good).

18. THE WORKS OF JAMES WILSON 239 (Robert Green McCloskey ed., 1967). Wilson also stated that "[C]ivil society must have existed, ... before civil government could be regularly formed and established. Nay, 'tis for the security and improvement of such a [condition], that the adventitious one of civil government has been instituted." Id. at 238 . 
Rehnquist Court's jurisprudence seems designed to protect the decentralized order and mediating institution $\mathrm{s}^{19}$ that Alexis De Tocqueville, the great analyst of American democracy, ${ }^{20}$ viewed as our society's distinctive principle, ${ }^{21}$ perhaps the appellation that summarizes the Rehnquist Court's approach best is Tocquevillian. In contrast to the centralization of France's ancient regime and the French Revolution's democratic centralism, Tocqueville observed that the vibrancy, innovation, and beneficence of American society did not come from its rulers but bubbled up from below. The secular associations of public-spirited citizens and churches and synagogues of spiritually oriented citizens were the underlying reason for the self-regulating order of our society. ${ }^{22}$ Tocqueville believed that while political factions try to use government coercion for their own ends, civil associations organize to meet the common goals of their members. Civil associations promote reciprocity among their members and create social norms from which other individuals can voluntarily choose. In this way they generate what modern sociologists would call social capital: the glue that binds society together through a group of interlocking networks. ${ }^{23}$

These civil associations have influence at the local level, making local government more responsive and contributory to a more public-spirited citizenry. ${ }^{24}$ Local governments also compete and thus are, in this sense, more similar to voluntary associations than the national government. Thus, in Tocqueville's conception, localism and mediating institutions are related social goods, because mediating institutions improve local government and local government has some of the virtues of mediating institutions. ${ }^{25}$

In this Article I will consider evidence for this emerging Tocquevillian jurisprudence in four disparate areas of the Rehnquist Court's doctrine, using recent cases to show the culmination of the Court's jurisprudential trends. First, the Rehnquist Court is continually reviving federalism in a structural constitutional sense: it prefers to have a market

19. Mediating institutions are associations that neither contribute inputs directly to democracy nor carve out an intimate personal sphere.

20. See Sanford Levinson, Religious Language and the Public Square, 105 HARv. L. Rev. 2061, 2069 (1992) (book review) (praising Tocqueville's "great analysis" of American democracy).

21. See Alexis De Tocqueville, Democracy in Amerrca (Phillips Bradley ed., 1990) [hereinafter DEMOCRACY IN AMERICA]. It is quite fair to identify Tocqueville with spontaneous order. Hayek entitled his most famous book, The Road To Serfdom (1944), after Tocqueville's phrase "road to servitude." See Alan O. EBENSTEIN, FRIEDRICH HAYEK 116 (2001).

22. For further discussion of the importance of associations for Tocqueville, see infra notes 215$18,247-49$ and accompanying text.

23. See Robert D. Putnam, Bowling Alone: The Collapse and Revival of American Community 22-24 (2000) (discussing the importance of social capital in America).

24. See Richard Pildes, The Destruction of Social Control Through Law, 144 U. PA. L. REV. 2055, 2064 (1996) ("Tocqueville articulates a mechanism through which local acts of cooperation become generalized toward a more public-regarding disposition ....").

25. For further discussion of this connection between mediating institutions and federalism in Tocqueville, see infra notes 103-07 and accompanying text. 
for governance in which states compete in laying out public policy responses rather than to have single solutions imposed from the center, at least in noneconomic areas crucial to civil society. For instance, in United States $v$. Morrison ${ }^{26}$ the Court demonstrated its commitment to protecting state (and local) autonomy. In striking down the Violence Against Women Act ("VAWA") on the grounds that it exceeded Congress's enumerated powers, ${ }^{27}$ the Court invalidated a law that purported to protect over half of society. Further, for the first time in decades the Court declared that it would insist on the state jurisdictional lines necessary for the functioning of competition, even if Congress made factual findings that the legislation addressed a problem that was of an interstate character. ${ }^{28}$ The revival of federalism helps re-establish the primacy of private ordering. Restricting federal power creates new areas in which individuals and civil associations are subject only to state regulation (as opposed to federal regulation, which can be more distant and less sensitive to private concerns). Moreover, because under federalism, states, like civic or religious associations, inust compete to satisfy their constituents, federalism itself has elements of private ordering built into its structure.

Second, the Rehnquist Court has bolstered the autonomy of mediating institutions, particularly civil associations, against government power. In Boy Scouts of America v. Dale, ${ }^{29}$ the Court permitted private associations to exclude homosexuals from positions that those associations believe are incompatible with homosexual status, allowing those associations to be a contributing force in shaping social norms about homosexuality. ${ }^{30}$ In doing so, the Court reinforced the autonomy of civil associations: associations whose value comes from their contribution to civil society rather than direct input into politics. This solicitude for civil associations contrasts with the Warren and Burger Courts, which focused on protecting the autonomy of those associations more directly connected to politics. ${ }^{31}$ The Rehnquist Court has underscored the importance of providing expressive autonomy to civil associations, at least of the noncommercial kind, by suggesting in a case examining political associations, California Democratic Party $v$. Jones ${ }^{32}$ that political and civil associations have congruent rights of expressive association. ${ }^{33}$ Similarly, in Board of Regents of the University of

26. 529 U.S. $598(2000)$.

27. Id. at 619 .

28. Id. at 614-15.

29. 530 U.S. $640(2000)$.

30. Id. at 656 (holding that forcing the Boy Scouts to include Dale as a scout leader would undermine the association's right to self-expression).

31. For a fuller discussion of the protection the political associations have previously received from the Court, see infra notes 67-70 and accompanying text.

32. 530 U.S. $567(2000)$.

33. Id. at 582 (citing Hurley v. Irish-American Gay, Lesbian and Bisexual Group of Boston, Inc., 515 U.S. 557 (1995) (a case concerning expressive rights of civil associations)). 
Wisconsin System v. Southworth, ${ }^{34}$ the Court created the constitutional space for government to aid civil associations so long as they did so in a viewpoint neutral manner. ${ }^{35}$

Dale is also significant since it is the second time in the fifty years since the civil rights movement began that the Supreme Court invalidated the application of an antidiscrimination law against private conduct. ${ }^{36}$ Thus, even in the area of discrimination, the Rehnquist Court is permitting private associations to help set social norms regarding the tolerable limits of discrimination in the noneconomic sphere rather than leave that decision entirely to the government. This perspective contrasts sharply with the Warren and Burger Courts, which allowed both state and federal governments essentially plenary power to eradicate any kind of discrimination. ${ }^{37}$

Third, the Rehnquist Court moved to permit the government to facilitate the working of religiously backed mediating mstitutions, so that they can compete to produce social norms on an equal footing with public, secular institutions. Understanding the importance of the private ordering of social norms through competition explains seemingly inconsistent Establishment Clause decisions. The Court invalidated school endorsed prayer at public school football gaines in Santa Fe Independent School District v. Doe, ${ }^{38}$ but decided Mitchell v. Helms ${ }^{39}$ in the same term, endorsing substantial government aid to private, religious schools, provided that both public and private schools, regardless of religious affiliation had access to the aid on a neutral basis. ${ }^{40} \mathrm{~A}$ jurisprudence that sustains a social order constructed from below rather than imposed by the government from above embraces both of these decisions: government can build an infrastructure for institutions, including religious institutions, and thus facilitate the value choices of citizens but cannot itself impose any religious practice on them.

This kind of jurisprudence also explains why the Rehnquist Court is using the Free Speech Clause rather than the Free Exercise Clause to expand the rights of religious organizations. In a series of cases, including

34. 529 U.S. 217 (2000).

35. Id. at 233.

36. The first was Hurley, 515 U.S. 557 (holding that Massachusetts could not apply its antidiscrimination law to require that the Boston St. Patrick's Day parade admit a group of Irish American homosexuals who wished to participate as an identifiable unit).

37. The many cases in which the Warren and Burger Courts allowed the national and state governments to regulate discrimination include: Katzenbach v. McClung, 379 U.S. 294 (1964) (upholding Congress's authority under the Commerce Clause to enforce antidiscrimination laws against a local, very small restaurant); Bob Jones University v. United States, 461 U.S. 725 (upholding IRS decision to refuse charitable deductions to discriminatory university without express congressional authorization); Roberts v. United States Jaycees, 468 U.S. 609 (1984) (upholding right of Minnesota to apply its antidiscrimination law to require that Jaycees admit women).

38. 530 U.S. $290,315-17(2000)$.

39. 530 U.S. 793 (2000).

40. Id. at 809 (plurality opinion of Thomas, J.). 
Good News Club v. Milford Central School ${ }^{41}$ and Rosenberger v. Rector and Visitors of University of Virginia ${ }^{42}$ the Court has required the government to provide facilities and, in some circumstances, even funding to religious civil associations if it extends facilities or funding to secular organizations. Similarly, there is no reason that the freedom of expressive association recognized in Dale should not extend to religious organizations to provide them with the autonomy to formulate and deliver their messages as they see fit. In contrast, the Court, in Employment Division v. Smith, ${ }^{43}$ declined to give religious organizations special exemptions from generally applicable laws. This decision, which may seem unsympathetic to religious associations, is nevertheless consonant with a jurisprudence where the government simply provides a neutral framework in which social norms generated by civil associations, regardless of the presence of religious affiliation or lack thereof, can compete on an equal basis.

Finally, the impulse toward nurturing decentralizing institutions extends even to criminal law's division of fact-finding between juries, a quintessential example of a decentralized and local body, and judges. In Apprendi v. New Jersey, ${ }^{44}$ the Court built on previous decisions to require a jury rather than a judge to decide whether any factor would raise a sentence beyond the statutory maximum. ${ }^{45}$ In contrast to judges, juries, as randomly chosen groups of citizens, represent decision makers more akin to civil associations. The underlying symbolic message of Apprendi is that citizens sitting together must exercise their collective judgment to determine any element of guilt that triggers legal authorization of additional punishment. In Apprendi, more clearly than in the other cases decided last term, Justices Breyer and Scalia explicitly discussed the conflict between centralized structures for sentencing and the local norms the jury system represents. It is too early to gauge the practical effects of Apprendi, but it may have sweeping implications for sentencing on both state and federal levels, ${ }^{46}$

41. 533 U.S. $98(2001)$.

42. 515 U.S. $819(1995)$.

43. 494 U.S. 872, 885 (1990) (holding that the Constitution does not require generally applicable laws to exempt religiously motivated conduct from their structures).

44. 530 U.S. $466(2000)$.

45. Id. at 476 ("IA]ny fact (other than prior conviction) that increases the maximum sentence for a crime must be charged in an indictment, submitted to a jury, and proven beyond a reasonable doubt.").

46. See Wystan M. Ackerman, Note, Precluding Defendants From Relitigating Sentencing Findings in Subsequent Civil Suits, 101 Colum. L. Rev. 128, 153 n.163 (2001) (suggesting that while implications of Apprendi are not entirely clear, the decision could threaten some aspects of the federal sentencing guidelines); see also Freya Russell, Note, Limiting the Use of Acquitted and Uncharged Conduct at Sentencing: Apprendi v. New Jersey and Its Effect on the Relevant Conduct Provision of the United States Sentencing Guidelines, 89 CALIF. L. REv. 1199 (2001) (arguing that Apprendi prohibits the use of the Relevant Conduct Provision of the federal sentencing guidelines to increase a sentence beyond that authorized by the statutory maximum for the offense of conviction). 
offering a promise of better infusing a community's social norms into government.

One way of understanding these developments, as a whole, is that the Rehnquist Court is sustaining so called "discovery machines" 47 in arenas where centralized systems, whether democratic or bureaucratic, are likely to perform deficiently. ${ }^{48}$ For example, federalism can be understood as a discovery machine because it creates an arena in which states must compete in offering different bundles of rights and enforcement regimes. Similarly, associative rights, whether exercised in the secular or religious sphere, provide an even better discovery mechamism: mediating institutions are closer to their members than states are to their citizens; and meinbers can more easily exit associations than citizens can exit states. Therefore, the Court should permit the government to facilitate civil associations and, absent a compelling state interest, should prevent the governinent from disturbing them. Finally, criminal juries better reflect social norms than judges. Accordingly, laws should make juries the discovery machines in sentencing rather than leave sentencing decisions to bureaucratic engines.

Since these discovery machines-states, secular and religious associations, and juries-mobilize greater popular engagement by the citizenry and are less subject to undue interest-group leverage, they may distill popular will better than centralized deinocracy. Thus, the Rehnquist Court's emerging jurisprudence, like Ely's ideal jurisprudence, can be seen as a process jurisprudence, one that seeks to convert the preferences of the people into social norms. In fact, the Rehnquist Court's jurisprudence better filtrates popular sentiment than Ely's because it follows the Constitution in making use of a variety of protected structures such as the states, civic associations, both secular and religious, and juries, when these structures better achieve the goal of government by the people than national democracy.

While these doctrinal developments represent the inost important trend of the Rehnquist Court, it is not clear whether they will succeed in ultimately transforming the Court's jurisprudence as a whole. First, the definitive success of the constitutive structures in protecting decentralized and spontaneous order remains uncertain. Constitutional discovery machines are delicate mechanisms whose ultimate value depends on the core eniotional attachments of citizens. Constitutional federalism's survival, for instance, may depend on the willingness of citizens to defend the autonomy of their states even when confronted by national policies that would be otherwise attractive. In the contemporary era, mass culture and the

47. I use the term "discovery machine" to refer to decentralized constitutive structures, including both local governments and civil associations, that create and express social norms.

48. I discuss the importance to democracy of social norms produced by decentralized institutions at notes $169-75,208-09,298-303,315-16$ and accompanying text. 
consequent loss of local attachments leave that premise open to question. Second, at least on the surface, there are potential conflicts among different aspects of the emerging jurisprudence of decentralization and spontaneous order; the potential conflict between the revival of federalism and the reinvigoration of rights of association illustrates this point. The latter set of rights can be used to strike down state legislation and thus may seem to conflict with federalism. At a deeper level, however, 1 will try to show how they can be reconciled as an attempt to push down noneconomic social ordering to the most decentralized structure that is constitutionally appropriate. ${ }^{49}$ Third, the Court's protection so far has been limited largely to protecting an autonomous sphere for competition in social norms. When states or private associations are engaged in commercial matters the Court continues to permit regulation by the national and state governments. My purpose in this Article is thus not only to highlight and explain the movement toward spontaneous order and decentralization in the Rehnquist Court's decision making, but also to attempt to resolve these tensions and explore how much further this movement may go.

Before describing the manner in which the Rehnquist Court is shifting constitutional jurisprudence toward a jurisprudence of decentralization, the Article canvasses the important changes in social experience and social theory that helped prompt this fundamental transformation. John Maynard Keynes once said, "the ideas of economists and political philosophers ... are more powerful than is commonly understood. Indeed the world is ruled by little else." ${ }^{\text {50 }}$ Supreme Court Justices, like all statesmen, are subject to these influences. Thus, in Part I, I show that social theory in general, and public choice theory in particular, has given us new reason to suspect that centralized democracy has systematic defects in producing beneficial social norms, thus prompting the Court to rediscover the constitutive structures that provide alternate mechanisms of production. ${ }^{51}$

Part II sets out the case that federalist structures inay generate better social norms and also discusses the importance of federalisin to Tocqueville's own description of what was beneficial about American democracy. This Part also reviews some of the recent cases in which the Court has strengthened federalism. It then assesses the extent to which the Court can revive federalism in a world where citizens no longer have the same attachments to their states that they did in 1789. The Part concludes by noting that while revitalizing federalism is an important element of

49. The state is preferred as the locus of norm creation to the federal government so long as the norms do not cause substantial externalities among states, and the civil association is preferred to the state so long as the norms do not cause substantial externalities among individuals. See infra notes 20308 and accompanying text.

50. John Maynard Keynes, The General Theory of Employment, INTEREst, and Money 383 (1954).

51. See notes $78-93$ and accompanying text. 
revitalizing a jurisprudence of spontaneous order, other constitutional structures for supplementing the social norms of national democracy are needed even more than they were at the time of the Framing because of the changed context generated by a stronger national identity in the modern world.

Part III describes the reason that civil associations are even better than states at generating social norms so long as these associations cannot coerce individuals to subscribe to them. Tocqueville saw the principle of civil association as one of the most central and beneficial principles of the New World because it allowed the accomplishment of beneficial public purposes without the supervision of the state. ${ }^{52}$ This Part reviews how the Supreme Court is revitalizing the civil associations by preventing the government from interfermg with the delivery and formation of their messages. The Part concludes by showing that just as the Supreme Court has prevented the government from interfering with expressive autonomy of civil associations, it has also permitted the government to facilitate civil associations by providing funding for them on a viewpoint neutral basis.

Part IV extends this analysis to religious associations. Tocqueville saw religion and religious associations in particular as essential to providing good social noruns, because they offer restraints on excessive materialism that is an inherent danger of a commercial republic. ${ }^{53}$ One of the difficulties in contemporary America is that the taxes assessed for the modern welfare state, particularly public schools, dry up private resources and impede religious associations from competing with private and public secular institutions in advancing their own religious-backed norms, particularly in the area of education. This Part shows that the Court is allowing the government to provide assistance that allows private religious schools to compete on an equal basis im the production of social norms so long as the government does so in a way that is neutral between religious and secular schools. The Court is also preventing the government from itself favoring certain religious-backed norms by supporting school-sponsored religious activity. The Part also shows that the Court has permitted religious associations to take advantage of the neutrality principle when it has required the government to make available school facilities to religious associations on an equal basis with secular associations. Finally, this Part defends the Supreme Court's refusal to exempt religiously motivated conduct from generally applicable laws as consistent with a jurisprudence of spontaneous order because by treating religious and secular associations equally, it allows them to compete in the production of social norms on an equal footing.

52. See infra notes $215-16,247-49$ and accompanying text.

53. See infra notes $315-16$ and accompanying text. 
Part V describes the important role the jury has in creating social norms distinct from those created by centralized democracy. Tocqueville saw the jury as a special-purpose civil association. ${ }^{54}$ Consistent with this view, a jurisprudence of spontaneous order would revitalize the jury as opposed to more bureaucratic methods of assessing guilt and punishment. The Part describes the manner in which the Court has been strengthening the role of the jury in sentencing by preventing judges from imposing punishments in excess of the statutory maximum. The Part then assesses the prospects of the decision for strengthening the role of the criminal jury in generating social norms.

Finally, Part VI addresses fundamental rights jurisprudence and argues that this jurisprudence is inconsistent with a jurisprudence of spontaneous order, because the Supreme Court is a centralized institution lacking the information and incentives to create beneficial social norms directly. Consistent with this view, the Rehnquist Court has been far more chary of creating new fundamental rights than the Warren or Burger Courts even if it has declined to overrule the landmark decisions of that era. ${ }^{55}$

\section{The Reorientation of THE SUPREMe Court's JuRISPRUdence}

It is much too simple to say that the Supreme Court follows the election returns. ${ }^{36}$ Politics matter, of course, in delimiting what is possible for the Court. But the Justices are appointed for life and come from the high echelons of the bar, a relatively elite group, unlikely to ratify unthinkingly the preferences of the denizens of a mass democracy. ${ }^{57}$ The most important political influence on the Court derives not from the electorate but from the political ideas and ideals of its era. ${ }^{58}$ Recognizing this influence does not mean that the Court directly applies current academic political theory or displays the markings of those theories on the surface of its opinions. Justices are not social scientists and their academic training is long past. Nor do Justices reflect various intellectual influences in a consistent and coherent mauner throughout their entire jurisprudence: theory is refracted through their prior experiences, their commitments, and their sense of how far the Court can translate intellectual theory into practice consistent with

54. See infra notes 396-97 and accompanying text.

55. Although it is true that the Rehnquist Court has not overruled previous fundamental rights precedents, one explanation for this caution is a desire to retain the political capital needed to move toward the revitalization of the conditions for spontaneous order.

56. See Peter Finley Dunne, Mr. Dooley's Opinions 26 (1901).

57. See Steven G. Calabresi, Textualism and the Countermajoritarian Difficulty, 66 GEo. WVASH. L. REv. 1373, 1387 (1998) (Supreme Court Justices are "part of an elite legal culture which can be quite resistant to new popular ideas").

58. Cf. Thomas G. Arthur, Farewell to the Sea of Doubt: Jettisoning the Constitutional Sherman Act, 74 CALIF. L. REv. 266, 376 (1986) (suggesting that the Court's Sherman Act theories are heavily influenced by the intellectual trends of various eras). 
constitutional principle. ${ }^{59}$ But as members of the intellectual community (here defined broadly as those who make a living by manipulating symbols), the Justices pick up the outlimes of broad social theories as they are reflected in the media. ${ }^{60}$ Moreover, the same salient historical events and currents of society that influence those theorists influence the Justices themselves.

For example, in the Lochner era the reigning laissez-faire theories of the day and even Herbert Spencer's Social Statics influenced the Court. ${ }^{61}$ More recently, and more importantly for our purposes, the Warren Court's jurisprudence unfolded from the hopeful perspective of that era (in continuity with the New Deal Court) that view national democracy as a powerful and relatively beneficent engine of social reform. ${ }^{62}$ The Warren Court continued to pursue the New Deal vision that to gain the centralized authority necessary for large-scale social reform, many of the features of the Constitution's original design that had limited the federal government's powver should no longer check it. Thus, structural checks provided by federalism and the separation of powers continued to be substantially weakened. ${ }^{63}$ Toward the end of the Warren Court's era, a leading constitutional theorist could argue that the courts should not enforce federalism and separation of powers at all. ${ }^{64}$ Given that The Federalist and Marbury $v$. Madison provide for the policing of the enumerated powers as their prime example of appropriate judicial review, the popularity of this theory was a mark of how comprehensive had been the triumph of the jurisprudence of centralized democracy at the expense of the original design. ${ }^{65}$

59. See David Rudenstine, Judicially Ordered Social Reform: Neofederalism and Neonationalism and the Debate over Political Structure, 59 S. CAL. L. REv. 449, 494 (1986) (discussing the influence of conflicting theories of political structure and limits these ideologies place on Justices' concepts of governmental structure).

60. For a discussion of how general social theories of the age in connection with interest groups often shape constitutional law, see John O. McGinnis, The Inevitable Infidelities of Constitutional Translation: The Case of the New Deal, 41 WM. \& MARY L. Rev. 177, 202-06 (1999).

61. See Lochner v. New York, 198 U.S. 45, 75 (1905) (Holınes; J., dissenting). For a discussion of the influence of these laissez-faire theories, see Richard HofstadTER, Soclal DaRWINISM iN AMERICAN THOUGHT (1959).

62. For a discussion of this aspect of the New Deal consensus, see Cass R. Sunstein, The Partial Constitution 40-67 (1993).

63. For a discussion of the collapse of separation-of-powers restraints, see Gary Lawson, The Rise and Rise of the Administrative State, 107 HaRv. L. REv. 1231, 1248-49 (1994), and for a discussion of the collapse of federalism, see Richard A. Epstein, The Proper Scope of the Commerce Power, 73 VA. L. REV. 1387 (1987).

64. Jesse H. Choper, Judicial Review and the National Political Process 175-76, 263 (1980) (suggesting that the Court should not enforce both federalism and the separation of powers respectively).

65. See Marbury v. Madison, 5 U.S. (1 Cranch) 137, 176 (1803) (suggesting that the Supreme Court must assure that Congress stay within its limited powers); THE FEDERALIST No. 78, at 435 (John Hainilton) (Clinton Rossiter ed., 1961) (arguing that judicial review was necessary to prevent Congress from overstepping the bounds established by the Constitution). 
By the time of the Warren Court, the plight of the African American minority also reinforced the need for centralized federal action because individual states were abetting state-sponsored discrimination. Moreover, as Ely notes, the problem of stereotypes and inequality were thought to so severely affect the outputs of democracy that the Warren Court constructed an elaborate jurisprudence to root them out by providing special solicitude for discrete and insular minorities under the Fourteenth Amendment. ${ }^{66}$

With the dissolution of federalism and other checks on the power of the federal government, advocates of social reform had to look elsewhere for restraint: the Warren Court found such a mode for restraint on the federal government in the reasoned deliberations of citizens in the democratic process. ${ }^{67}$ Under this new paradigm, the citizens' ability to engage in sustained social criticism and vote their rulers out would prevent a powerful state from becoming a tyrannical one. If the ability of citizens to criticize and ultimately replace the government contained the power of the state, the First Amendment inevitably focused on "open political dialogue and process." ${ }^{68}$ Free speech became the fuel of the engine of social reform by encouraging the widest possible dissemination of social ideas and political programs ${ }^{69}$ Consistent with this view, the Burger Court deployed the First Amendment to protect rights of political associations because such associations provide essential mputs for democracy. ${ }^{70}$

Although perfecting collective democratic processes was the most important organizing principle of the Warren Court, it was not the only one. The Warren Court also began to create constitutional doctrine to protect a personal sphere for individuals to achieve self-realization beyond the reach of centralized authority. ${ }^{71}$ The Burger Court continued this trend by

66. John Hart Ely has offered an interesting retrospective reconciliation of democracy with such strict scrutiny as necessary to make democracy work by reducing its reliance on unjustified stereotypes. See ELY, supra note 4, at 155-70.

67. See David Yassky, Eras of the First Amendment, 91 Colum. L. Rev. 1699, $1734-37$ (1991) (understanding increased protections afforded by the First Amendment after the New Deal as a way of facilitating majority control of the ncwly empowered state).

68. See ELy, supra note 4, at 112 (1980) ("The central function" of the First Amendment is "to assur[e] an open political dialogue and process.").

69. See, e.g., Roth v. Umited States, 354 U.S. 476, 484 (1957) (The First Amendment was "fashioned to assure unfettered interchange of ideas for the bringing about of political and social changes ....").

70. See, e.g., NAACP v. Claiborne Hardware Co., 458 U.S. 886 (1982) (permitting political associations to engage in a boycott that would otherwise be invalid under the antitrust laws); In re Primus, 436 U.S. 412 (1978) (voiding a Bar Association rule that inhibited litigating organizations from pursuing ideological agenda); Abood v. Detroit Bd. of Educ., 431 U.S. 209 (1977) (protecting the right of workers not to have their union dues used for ideological causes with which they disagree).

71. Griswold v. Connecticut, 381 U.S. 479 (1965) (upholding a right of access to contraceptives). More generally, the existence of this personal sphere was perceived as one of the most important demarcations separating the modern social democracy of the West, including the United States, from the communist states of the East. See Richard Lowenthal, The Future of Socialism in the Advanced Democracies, in ThE Socialist IDEA 222, 223 (Leszek Kolakowski \& Stuart Hampshire eds., 1973) 
deepening the rights to intimate association and abortion as an expression of a politically liberal vision of the content of personal autonomy. ${ }^{72}$ The Court also used the First Amendment to protect this personal sphere by permitting uninhibited rights of self-expression. ${ }^{73}$

But while the Warren Court both expanded the power of the centralized state and carved out a sphere of personal expression and sexual autonoiny, its jurisprudence did not concentrate on protecting institutions that mediate between the centralized state and the individual. For instance, while the Warren and Burger Courts used the First Amendment to expand political inputs, they did not wield this principle as forcefully on behalf of civic, as opposed to political, associations. Indeed, the Burger Court permitted the government to regulate what could be regarded as expressive civil associations. ${ }^{74}$ Moreover, the Warren and Burger Courts often construed the First Amendment to prohibit the government from providing the same assistance to educational activities of religious associations that it did to secular associations. ${ }^{75}$

The lack of any particular solicitude for mediating institutions was quite consistent with a jurisprudence that sought to perfect centralized

(suggesting that Western social democracy, unlike communism, seeks a regime that combines personal autonomy with social control over economic forces).

72. The paradigmatic case here is Roe v. Wade, 410 U.S. 113 (1973). See Mark A. Graber, The Clintonification of American Law: Abortion, Welfare, and Liberal Constitutional Theory, 58 OHIO ST. L.J. 731, 763 (1997) (discussing the relation of fundamental rights jurisprudence to political liberalism).

73. For a discussion of this rationale of the First Amendment, see C. Edwin Baker, Realizing Self-Realization: Corporate Expenditures and Redish's The Value of Free Speech, 130 U. PA. L. REv. 646, 653-54 (1982) (supporting self-realization afforded by the First Amendment).

74. See Roberts v. United States Jaycees, 468 U.S. 609 (1984) (upholding the application of Minnesota's human rights law to require Jaycees to admit women as regular members). Early decisions of the Rehnquist Court continued this trend. See N.Y. State Club Ass'n v. City of New York, 487 U.S. 1 (1988) (rejecting facial challenge to New York City ordinance requiring clubs where business is conducted to admit women); Bd. of Dirs. of Rotary Int'l v. Rotary Club of Duarte, 481 U.S. 537 (1987) (upholding the application of California human rights laws to require Rotary Club to admit women). For a discussion of the recent Rehnquist Court decisions, see infra Part II.B.

75. See, e.g., Wolman v. Walter, 433 U.S. 229 (1977) (striking down a state program for lending instructional materials to students at private schools and a state program to pay for field trips by students at private schools); Meek v. Pittenger, 421 U.S. 349 (1975) (invalidatimg program that would have provided certain instructional materials and auxiliary services to private schools). The Burger Court may have been even less favorable to government assistance to religious schools than the Warren Court. See, e.g., Bd. of Educ. v. Allen, 392 U.S. 236 (1968) (upholding the "child benefit" of furnishing secular textbooks by the public to parochial school students provided that secular and religious uses of publicly funded materials were not entangled). For an analysis of the influence of Establishment Clause jurisprudence on the Warren Court's position toward school aid, see Mark C. Rahdert, A Jurisprudence of Hope: Justice Blackmun and the Freedom of Religion, 22 HAMLINE L. REv. 1, 55 (1998) ("The [Warren] Court obviously saw its role in establishment cases as striking a balance between the government's legitimate interest in furthering secular educational goals through private educational means, and the danger that government resources would be used to advance a religious message."). 
democracy. ${ }^{76}$ If national government could conduct reform rationally and scientifically with inputs from the public through the electoral process, there was less need for civil associations to provide competing values. Moreover, different religious associations, like different regions nurtured by federalism, could sustain pockets of ideas quite hostile to enlightened national reforms and thus should not be supported by the funding the government makes available to secular institutions pursuing similar goals, such as education. ${ }^{77}$ Precisely because of the power of these associations, the Warren and Burger Courts were not eager to advance religious influences on education, the most essential institution for shaping values and views of the next generation.

Thus, speaking broadly, implicit in the Warren Court's, and in much of the Burger Court's, jurisprudence was a coherent political theory of social reform through centralized democracy. Inputs from a vigorously protected right of free speech fueled this centralized democracy, circumscribed only by judicial doctrines designed to protect minorities' personal sphere of expressive and sexual autonomy beyond democratic choice. The Court provided less specific constitutional protection, however, for civil associations and local government, institutions both independent of and competing with national democracy.

However, the political world today and the political theory that maps it look very different from those of either the late New Deal or the Warren Court. Skepticism about highly centralized government as a rational planner of broad social reform has grown because the Great Society's reforms are widely believed to have had certain counterproductive consequences. ${ }^{78}$ Moreover, developments in political theory have offered explanations for some of the difficulties that centralized reform has encountered.

76. Indeed, the concern that civil associations, particularly religious associations, will inhibit the beneficent social order is reminiscent of defenders of a unitary state, whether Hobbes or Rousseau. See Jean-Jacques Rousseau, The Social Contract (1762), reprinted in SocIAL ConTract: EsSAYS BY LOCKE, HUME AND RousSEAU 194 (Emest Barker ed., Gerard Hopkins trans., 1948) (arguing that iu order to express the general will "it is essential that there be no subsidiary groups within the State, and that each citizen voice his own opinion and nothing but his own opinion"). See also ROBERT A. NISBET, COMmunity AND POWER 129-52 (1962) (showing that both Rousseau and Hobbes wished to contain the autonomy of civil associations so they would not interfere with the power of the state).

77. See Liam Seamus O'Mellin, The Sanctity of Association: The Corporation and Individualism in American Law, 37 SAN DiEGo L. REv. 101, 110-16 (2000) (discussing unfavorable view of associations that emerged from the French Revolution's celebration of a strong, unitary democracy). For a modern echo of this view, see James S. Liebman, Voice, Not Choice, 101 Y ALE L.J. 259 (1991) (favoring public school education over private school education). Proponents of a strong democratic state might logically except from this hostility associations that contribute directly to democracy, like parties and political associations.

78. See, e.g., Charles Murray, Losing Ground (1984) (describing failures of antipoverty programs launched in the 1960s). 
Public choice theory, for instance, has cast doubt in various ways on the coherence and efficacy of collective decision making. ${ }^{79}$ In particular, public choice theory has shown that cohesive groups, called special interests, may be able to exercise political power out of proportion to their numbers to obtain resources and status for theinselves. ${ }^{80}$ In contrast, since the diffuse citizenry has little leverage on centralized democracy, it is rationally ignorant of much government policy. ${ }^{81}$ This rational ignorance translates into symbolic politics where voters cast their ballots for politicians who make them feel good about themselves. ${ }^{82}$

Social changes have exacerbated these trends. The national government's susceptibility to special interests has increased because the declining costs of information transmission have magnified an interest group's ability to influence government. ${ }^{83}$ As a result of these changes, interest groups are better able to organize and monitor benefits to their members, thus avoiding free rider problems. Interest groups are also better able to

79. Public choice is premised on the notion that individuals act in politics, as in markets, for reasons of self-interest. See Edward L. Rubin, Getting Past Democracy, 149 U. PA. L. REV. 711, 744 (2001). Public choice has a strong antiutopian flavor and engenders some skepticism about using government to achieve radical reform in the public interest. See also DenNis C. MUELLER, Public CHOrce II 406 (1989) (discussing modern theorems that "raise fundamental questions about the possibility of establishing collective choice procedures establishing minimally appealing normative properties").

80. See Mancur Olson, The Logic of Collective Action 141-44 (1965). Special interest groups exert their influence in the political process in a variety of ways. First, they are able to monitor what is actually transpiring in the political process, such as what legislation is voted on and how the vote affects their interests. See, e.g., Michael A. Andrews, Tax Simplification, 47 SMU L. REv. 37, 42 (1993). Second, special interests can often use experts to persuade legislators of their position. See, e.g., Jonathan R. Macey, Special Interest Groups Legislation and the Judicial Function: The Dilemma of Glass-Steagall, 33 EmoRY L.J. 1, 17-21 (1984). Third, special interests are able to conduct a coordinated and coherent campaign to publicize their position in the inedia. See William Dubinsky, Book Note, 90 Mich. L. Rev. 1512, 1514 (1992) (reviewing Daniel A. FArber \& Philip P. Frickey, LAW AND PUBLIC CHOICE (1991)) (explaining that special interests can generate powerful publicity campaigns). Finally, special interests may exercise great leverage over legislators through campaign contributions or independent political expenditures. See Daniel Hays Lowenstein, Political Bribery and the Intermediate Theory of Politics, 32 UCLA L. REv. 784, 826-28 (1985).

81. "Rational ignorance" describes the systematic tendency of diffuse citizens to pay little attention to political information. This phenomenon occurs because acquiring political information is both costly and unproductive. It is costly because to acquire such information, individuals must invest time they could be using for other more lucrative or pleasurable enterprises. It is unproductive because the principal instrumental use of such information is to gnide voting, but the vote of any individual is unlikely to influence the outcome of an election. See MUELLER, supra note 79, at 205-06.

82. For a thorough discussion of the reasons that voters vote for symbolic or expressive reasons, see Geoffrey Brennan \& Loren Lomasky, Democracy and Decision: The Pure Theory of ELECTORAL PROCEDURE 19-53 (1993) (demonstrating that voters are willing to vote for symbolic reasons that make them feel good, because the monetary returns from a vote are likely to be negligible).

83. See Frank H. Easterbrook, The State of Madison's Vision of the State: A Public Choice Perspective, 107 Harv. L. Rev, 1328, 1334-35 (1994); Peter Schuck, Against (and For Madison): An Essay in Praise of Factions, 15 YALE L. \& PoL'y REv. 553, 580 (1997). 
monitor members of Congress, thus eroding the ability of legislators to act independently of these special interest groups. ${ }^{84}$

In contrast, the average citizen has become less focused on government activities because the consumption value of politics declined. With literally hundreds of channels for entertainment, politics has trouble competing for the average citizen's attention, which is less focused on political issues. ${ }^{85}$ Indeed, the era where the Lincoln-Douglas debates were the most entertaining show in town is long past. ${ }^{86}$ The result is a national domestic politics with a tendency to alternate between satisfying special interests and making grand symbolic gestures, neither of which is conducive to registering the real will of the majority or making effective social policy. In this light, the Rehnquist Court has compelling reasons to consider revitalizing the protections contained in the Constitution for localized institutions, both governmental and private, in order to engender more civic engagement.

Moreover, following the demise of communism as an ideal and the decline of socialism, the advantages of competition are receiving more respectful consideration as the defccts of centralized decision making seem more apparent. ${ }^{87}$ In an era where economic markets proved so effective, it is not surprising that competition among states and among mediating institutions-concepts implicit in the original Constitution-should receive renewed attention as a potentially useful organizing principle for society.

In addition, while centralized government has seemed less effective at domestic reform, commentators have expressed concern about the vitality of mediating and communal institutions. For instance, in his recent book, Bowling Alone ${ }^{88}$ Robert Putnam has mapped the decline of civil associations in America, both secular and religious. ${ }^{89}$ Accordingly, it may not be enough for government simply to remove barriers from these associations; it may need to provide the infrastructure to help them flourish anew. ${ }^{90}$

This new experiential and theoretical understanding of the political world prompts reconsideration of past constitutional jurisprudence. If centralized democracy is not a sure engine of social reform, more decentralized democracy could offer a way to discover better social regimes through experimentation with a wider range of social arrangements that would suit

84. See Easterbrook, supra note 83, at 1335-37.

85. See John O. McGinnis, The Partial Republican, 35 WM. \& MARY L. Rev. 1751, 1791 (1994) (book review).

86. For a discussion of the entertainment value of the Lincoln-Douglas debates, see DAvid Zarefsky, Lincoln Douglas and Slavery in the Crucible of Public Debate 18 (1990).

87. See Martha Minow, Choice or Commonality: Welfare and Schooling After the End of Welfare as We Knew It, 49 DuKe L.J. 493, 497 (1999) (describing the "triumph of the market" and its consequences in many spheres of social life).

88. See PuTNaM, supra note 23.

89. See id. at 48-79 (discussing decline of civic and religious participation).

90. Id. at 405-06. 
diverse preferences. Moreover, if special interests are likely to distort the norms democratic decision making reaches, a constitutive structure needs additional mechanisms to assure, in Mancur Olson's phrase, that an "encompassing interest" rather than special interests governs decision making. ${ }^{91}$ Such an encompassing imterest (the diffuse majority or supermajority of citizens) is more likely to choose norms that advance the public interest because, unlike special interests, a diffuse majority is not primarily focused on using the government to obtain resources and status for itself at the expense of others. ${ }^{92}$ As discussed at greater length below, a structural feature of American constitutionalism, federalism, contains a ready-made mechanism that both decentralizes decision making and restrains special interests. ${ }^{93}$

Thus, the realization that centralized democracy is an imperfect mechanism for finding social norms sets the stage for the Rehnquist Court's rediscovery of the decentralizing structures of the Constitution that have been obscured by a past jurisprudence that pursued other values. That jurisprudence will focus on allowing the government to facilitate alternative discovery machines while preventing it from obstructing these mechanisms. Thus arises a netv constitutional solicitude for mediating institutions because these institutions, closer to their engaged participants and less driven by special interests, can better take account of citizens' sentiments. These associations are not valuable in the way they were in the Warren Court paradigm where they helped contribute to democracy. Instead, they are independently valuable because they themselves generate potentially beneficial norms for society through their competition. The norms that survive this market-test have some claim to being beneficial. ${ }^{94}$ Indeed, competing private associations must reflect value changes or lose members. Yet even those associations that lose members can shelter mimorities who

91. See Mancur Olson, Power and Prosperity 15-16 (2000) (discussing the necd to restrain interest groups to assure that prosperity). Thus, unlike in the Warren era, a principal concern of our era is to restrain minority factions rather than empower them. To be sure, the classic minority factions against which public choice warns are not racial and ethnic minorities per se, but small cohesive groups generally sharing economic interests. Nevertheless, the notion that "discrete and insular minorities" are necessarily powerless $m$ the political process is simply wrong from the public choice perspective. See Geoffrey P. Miller, The True Story of Carolene Products, 1987 SuP. Cr. REv. 397, 428 (1987).

92. OLson, supra note 91 , at 15-16.

93. For this discussion sce infra notes 101-15 and accompanying text.

94. For further discussion of this point, see infra notes 207-17 and accompanying text. If, as some suspect, we are experiencing rapid technological changes, private associations are even more useful in aiding society in discovering the appropriate norms to address change. Under these circumstances, private associations are even more beneficial because, like markets, they accumulate infornation dispersed throughout the country. $C f$. Robert $\mathrm{D}$. Cooter, Decentralized Law for a Complex Economy: The Structural Approach to Adjudicating the New Lav Merchant, 144 U. PA. L. Rev. 1643, 1646 (1996) (arguing decentralization is particularly necessary for economies in complex, technologically advanced societies). If social norms change in some measure as social facts change, private associations are in a better position to gather the knowledge to respond to these changes. 
do not agree with the prevailing norms in society. If these associations perform such a useful function, the First Amendment naturally becomes a vehicle for protecting such associations, even when they have nothing to do with politics, from encroachment by centralized democracy. ${ }^{95}$

Secular associations are not the only potentially useful associations for discovering norms and sheltering those who may not agree with the prevailing norms. Religious associations are necessary as well, particularly because religions offer a useful framework through personal attachment and restraints on self-interest that help certain norms flourish. ${ }^{96}$ For instance, sexual restraint may be a positive norm for society, or at least in the long-term interest of some people in society, but at any particular moment sexual restraint is obviously fighting against immediate human impulses. Accordingly, a religious structure may be necessary to provide this norm the strength to compete against others in a society in which individuals freely choose among competing norms. If religions have some peculiar advantages in some circumstances for the generation of beneficial social norms, it provides an impetus to return to a construction of the First Amendment's religion clauses that does do not prohibit the government from helping to build an infrastructure that facilitates religious associations. Here too the changing paradigm of political theory suggests a major shift in previous Establishment Clause jurisprudence to permit government to provide more aid to private schools, including religious schools, secular charities, and faith-based charities so long as this aid is distributed on a neutral basis.

Finally, juries resemble a mediating institution, albeit one drawn together for a limited purpose established by law. Because they are drawn randomly from the community to reason together on a set problem, juries bring an attention and seriousness to their deliberations that are largely absent from large-scale politics. They thus properly temper and supplement the norms set in the political arena. Moreover, because they are drawn from the community, they reflect community sentiment better than judges. A jurisprudence sympathetic to social discovery through spontaneous order and decentralization naturally will seek to move toward the larger role for the jury the Framers envisioned.

95. Indeed, if the First Amendment remained only concemed with protecting the inputs into democracy, it can be seen as exacerbating the disproportionate power of special interests because special interests are focused on shaping these inputs. See Easterbrook, supra note 83, at 1334-35 (noting that communication and transportation enable interest groups to organize, keep track of changes in their benefits, and monitor the behavior of members of Congress).

96. Indeed, considered objectively (that is, outside any particular religious viewpoint), religions have flourished precisely because they offer more efficacious frameworks for certain social norms than secular organizations. It may well be that these frameworks succeed because they comport with natural law. On the differences between the perspective of spontaneous order and natural law, see Douglas W. Kmiec, Liberty Misconceived: Hayek's Incomplete Relationship Between Natural and Customary Law, 40 AM. J. JuRIs. 209 (1995). 
Although each of these institutions (federalism, secular and religious mediating institutions, and juries) have strengths, they also have weaknesses. Local governments can be parochial and corrupt; ${ }^{97}$ mediating institutions can be divisive, ${ }^{98}$ juries can act irresponsibly. ${ }^{99}$ The Rehnquist Court's jurisprudence does not favor these institutions simplistically in every case. Instead, in light of experience, the Court is recalibrating the balance between national and state government, civil associations and governmental power, jury and judges, and moving the balance closer to that envisioned by the original Constitution.

Accordingly, Part II of this Article will address the extent to which the four areas (federalism, freedom of association, religious association and establishment, and criminal law) are contributing to an emerging jurisprudence of decentralization and spontaneous order. For each area, the Article describes the recent cases that demonstrate the Court's movement toward this jurisprudence. It then explores how mucl farther the new jurisprudence has to go and whether it is likely to get there. At each stage, Alexis de Tocqueville is our Virgil, because more than one hundred fifty years ago Tocqueville articulated the essential elements of spontaneous order within American democracy to which the Court is now returning. We begin with the structure that was most important to the original Constitution: federalism. ${ }^{100}$

\section{II}

Federalism: Reconstituting a Spontaneous ORder of Governance

\section{A. Federalism's Contribution to Private Ordering and Its Decline}

Federalism was the Framers' primary way of assuring that government would act to reinforce the beneficial social norms that arise from civil society rather than supplant them. A happy paradox of federalism is that two interlocking governments can be more hospitable to spontaneous order than a unitary state. The key to maintaining a decentralized structure is to use each level of government to constrain the other. In the original Constitution, the states brought the federal government into being but strictly constrained its authority by granting it only certain enumerated

97. See, e.g., Richard Thompson Ford, The Boundaries of Race: Political Geography in Legal Analysis, 107 HARV. L. REv. 1841, I921 (1994) (detailing the parochialism and other defects of local government).

98. See Gerard V. Bradley, The No Religious Test Clause and the Constitution of Religious Liberty: A Machine That Has Gone of Itself, 37 CASE W. REs. L. REv. 674, 745 (1987) (suggesting that mediating institutions, like any entity that makes truth claims, can be divisive).

99. See Richard A. Nagareda, Outrageous Fortune and the Criminalization of Mass Torts, 96 MrCH. L. REv. 1121, 1173 (1998) (acknowledging the possibility of nunaway juries).

100. See, e.g., John C. Yoo, Judicial Review and Federalism, 22 Harv. J.L. \& Pub. PoL'y 197, 203 (1998) (noting that federalism was conceived as "the fundamental corncrstone of the Founders" liberal republic"). 
powers. The Framers limited the essential domestic function of the national government to sustaining a free trade zone for the exchange of goods and services among the former colonies and to providing for a common currency. ${ }^{101}$ So circumscribed, the national government posed little threat to the resources and personal liberties necessary to sustain private associations. ${ }^{102}$ Moreover, the national republic's size would facilitate performance of these functions, because the factions within the republic that would lose from trade counterbalanced those that would benefit. ${ }^{103}$

The Constitution left the rest of domestic regulation to the states. Although the states were repositories of enormous and potentially tyrannical powers, the free movement of goods and people among them restrained their ability to use their power at the behest of interest groups to oppress the liberty of or extract wealth from their citizens. If the states exercised their power unwisely, free citizens could take themselves or their capital elsewhere. ${ }^{104}$ Thus, the Constitution's strictly enumerated powers restrained the federal government, which in turn restrained the states through the competition that the federal government maintained by keeping open the avenues of trade and investment. ${ }^{105}$

101. See, e.g., U.S. CoNST. art. I, $\S 8$, cl. 8 (providing Congress with power to regulate interstate commerce). Cf. Randy E. Barnett, The Original Meaning of the Commerce Clause, $68 \mathrm{U}$. CHI. L. Rev. 101,146 (2001) (suggesting that the original meaning of the Commerce Clause shows that it was intended to permit Congress to remove barriers to trade); John O. McGinnis \& Mark L. Movsesian, The World Trade Constitution: Reinforcing Democracy Through Trade, 114 HARv. L. Rev. 511, 536-42 (2000) (discussing the federal government's central role in maintaining a free trade zone); Richard A. Posner, The Constitution as an Economic Document, 56 GEO. WASH. L. REv. 4, 17 (1987) (viewing the Commerce Clause as a charter for free trade); David G. Wille, The Commerce Clause: A Time for Reevaluation, 70 Tul. L. Rev. 1069, 1077 (1996) (stating that the original purpose of the Commerce Clause was to promote free trade).

102. The states had representation in the structure of the federal government so that they could keep the national power within its proper bounds. For instance, a Senate selected by the state legislatures had to consent to the Justices who would police the enumerated powers of Congress. U.S. Consr. art. I, $\S 3$, cl. 1; U.S. CoNST. art II. § 2, cl. 2.

103. See McGinnis \& Movsesian, supra note 101 , at $539-40$ (discussing why national institutions are more likely to pursue free trade among the states than state legislatures). For discussion of this function of the large republic, see supra note 12. In contrast, if the centralized jurisdiction undertook regulatory functions, it more likely would be captured by special interests. McGinnis \& Movsesian, supra note 101, at 556-57. Indeed, the advantage interest groups have over centralized government regulation motivates them to favor centralization of governmental powver. See Barry Friedman, Valuing Federalism, 82 MinN. L. REv. 317, 373-75 (1997).

104. An essential flaw in the original Constitution was its failure to make all citizens free-a precondition for constitutional federalism to work for everyone. The Thirteenth Amendment as well as federal legislation to enforce its promise were essential if the benefits of constitutional federalism were to be made available to all Americans. Moreover, even with the Thirteenth Amendment the Court needed to enforce its dormant commerce clause jurisprudence to facilitate migration of African Americans. See David E. Bernstein, The Law and Economics of Post-Civil War Restrictions on Interstate Migration by African-Americans, 76 TEx. L. REv. 781, 818 (1998) (showing that the Supreme Court failed to invalidate restrictions on interstate migration under the dormant commerce clause).

105. See Richard A. Epstein, Exit Rights Under Federalism, 55 LAw \& ConTEMP. ProBs. 147, 149 (1992) (arguing that federalism is a check on the monopoly of governunent power because 
Federalism thus limits the government from engaging in excessive regulation and wasteful spending on behalf of interest groups. Some economists today explain that because of these limitations, the original constitutional design of a federalist free-trading system facilitated the United States' steady growth, allowing it to become an economic superpower by the beginning of the twentieth century. ${ }^{106}$ But federalism also created spaces for what Tocqueville saw as the distinguishing and sustaining feature of American democracy: the principle of association. This principle nurtures an energy of civic engagement that then could be transmitted throughout the country. ${ }^{107} \mathrm{~A}$ divided and limited government provides space for civil associations of all kinds because it does not take the resources necessary to support them and leaves objectives for people to pursue in common purpose. In contrast, as Tocqueville perceived, a unitary, majoritarian state is more likely to take the requisite resources and treat civil associations badly because they would be the sole barrier between it and absolute power..$^{108}$

Federalism not only sustains civil associations, its very structure builds into political life some of the advantages of spontaneous order. First, it creates a marketplace in which state governments must compete, much like private associations. By placing state governments in competition with one another, it forces them to be efficient in addressing externalities like pollution or criminal violence within their jurisdictions. ${ }^{109}$ As with other

individuals can move from state to state). Some have argued that competition among the states nevertheless has a substantial cost, because it encourages a race to the bottom in such matters as environmental regulation. See, e.g., Kirsten H. Engel, State Environmental Standard Setting: Is There a "Race" and Is It "To the Bottom?", 48 Hastings L.J. 271, 275 (1997) (sketching the basic race-tothe-bottom argument); Katherine Van Wezel Stone, To the Yukon and Beyond: Local Laborers in a Global Labor Market, 3 J. SMall \& EMERGING Bus. L. 93, $95-98$ (1999) (describing the race-to-thebottom argument in the context of labor conditions). The best recent scholarship, however, suggests that there will not generally be a race to the bottom, absent interjurisdictional spillover effects. See, e.g., Richard L. Revesz, Rehabilitating Interstate Competition: Rethinking the "Race-to-the-BottomRationale" in Environmental Regulation, 67 N.Y.U. L. REv. 1210 (1992). For further discussion, see infra notes 150-54 and accompanying text.

106. See, e.g., Posner, supra note 101 , at 30 ("[F]ederalism may be the most important contribution of American constitutionalism to economic growth."); Barry R. Weingast, The Economic Role of Political Institutions: Marhet-Preserving Federalism and Economic Development, 11 J.L. ECON. \& ORG. 1, 24-28 (1995).

107. 1 DEMOCRACY IN AMERICA, supra note 21, at 106. Tocqueville includes both profit and nonprofit civil associations within the principle of association. $I d$. at 108. For nore on this aspect of Tocqueville's view of federalism, see infra note 115 and accompanying text. For a perceptive discussion of the importance of federalism to Tocqueville, see A.E. Dick Howard, Garcia and the Values of Federalism: On the Need for a Recurrence to Fundamental Principles, 19 GA. L. REv. 789, 790 (1985).

108. See 1 Democracy IN America, supra note 21, at 271 (seeing the focus of the federal government on a relatively few objects and the absence of "centralized administration" as essential to preventing tyranny and preserving civil society).

109. See Mark Seidenfeld, Microeconomic Predicates to Law and Economics 63 (1996) (describing externalities as costs or benefits that are not voluntarily assumed in market transactions). We describe costly externalities as negative externalities and beneficial externalities as positive 
forms of spontaneous order, states produce goods (in this case, public goods) to address the problems within their jurisdiction in a manner that efficiently responds to the preferences of their members (in this case, the citizens of their state). ${ }^{110}$ Furthermore, because of the spontaneous ordering of competing states, they will readily copy the successful innovations of other states. Here, that means creating a "laboratory of democracy" where the successful experiments of yesterday become the effective public policy of tomorrow. ${ }^{111}$ Second, like different associations, different states provide different political niches for a diverse people, responding to different preferences with different goods. ${ }^{112}$ Inhabitants of San Francisco simply have different preferences and needs from those in Dubuque, and uniform rules failing to take account of this diversity will leave them alienated from their government. Third, like civil associations, federalism increases civic responsibility. Political scientists have frequently noted that in large governments citizens behave strategically, making it harder to gain agreement on the public goods that will improve the community. ${ }^{113}$ Federalism and the related but more encompassing principle of subsidiarity, where states then devolve powers to localities, temper strategic behavior and substitute in its place the genuine concern of one citizen for another. ${ }^{114}$

Thus, the dual structure of government mobilizes the civic engagement necessary for national as well as local government. As Tocqueville himself said:

It is incontestably true that the love and the habits of republican government in the United States were engendered in the township and in the provincial assemblies ... it is this same republican spirit, it is these manners and customs of a free people, which are

extemalities. Private associations without coercive power cannot readily address externalities because of free-riding problems. Cf. J. Gregory Sidak \& Daniel F. Spulber, Deregulatory Takings and Breach of the Regulatory Contract, 71 N.Y.U. L. REv. 851, 935 (1996) (showing that free-riding makes it necessary for government to supply collective goods like property rights).

110. For a definition of public goods, see MUeller, supra note 79, at 11 (defining "public good" as one that must be supplied jointly and from the enjoyment of which it is impossible or impractical to exclude people). The federal government under the Commerce Clause can address externalities that go beyond the state's jurisdiction, like interstate pollution. See McGinnis \& Movsesian, supra note 101 (describing interstate externalities as distortion of commerce that may call for a response by the central administration in a federal regime). See also infra notes 150-53 and accompanying text (describing efficient roles for state government and national government respectively).

111. The allusion is to New State Ice Co. v. Liebmann, 285 U.S. 262, 311 (1932) (Brandeis, J., dissenting).

112. For discussion of the way associations can perform this function, see MuELLER, supra note 79 , at $149-73$.

113. See id. (discussing the difficulty that strategic voting poses for the production of appropriate public goods).

114. See Michael W. McConnell, Federalism: Evaluating the Founders' Design, 54 U. CHI. L. Rev. 1484, 1510 (1987) (quoting Adam Smith). See also Pildes, supra note 24, at 2064 (discussing the manner in which Tocqueville believed that the reciprocity promoted by localism could enhance the public-spiritedness of citizens). 
engendered and nurtured in the different States, to be afterwards applied to the country at large. ${ }^{115}$

Despite these advantages, constitutional federalism has been declining for the better part of a century. The story is a relatively familiar one and will not be retold at length here. In the Progressive Era, pressure developed for a more centralized structure of governance. ${ }^{116}$ The Sixteenth Amendment, permitting a federal income tax, removed a major constraint on the federal government by giving it access to almost unlimited revenues. ${ }^{117}$ The Seventeenth Amendment, terminating the election of Senators by state legislators, stripped the states of their principal institutional protectors in Congress. ${ }^{118}$ In conjunction, these two progressive shifts substantially increased federal power at the states' (and federalism's) expense.

In the 1930s the Supreme Court weakened federalism still further. It eliminated the remaining constitutional limitations that prevented the federal government from directly regulating manufacturing, thereby gravely weakening regulatory competition among the states and centralizing power in Washington. ${ }^{119}$ Perhaps the ultimate indignity that federalism suffered in this period was Wickard v. Filburn. ${ }^{120}$ In that case, the Supreme Court upheld Congress's authority to regulate a farming family's consumption of its own wheat on the ground that the cumulative effects of such home consumption affected commerce and therefore was withm Congress's power to regulate under the Commerce Clause. ${ }^{121}$ After Wickard, it seemed that nothing was beyond Congress's power to regulate and that, therefore, the system of enumerated powers that sustained constitutional federalism was dead.

\section{B. The Rehnquist Court's Revival of Federalism}

In United States v. Lopez, ${ }^{122}$ the Rehnquist Court began to revive constitutional federalism by making clear that, as a matter of the Constitution's text and structure, Congress's commerce authority was not plenary and did not reach intrastate noncommercial matters. For the first time im five

115. 1 Toceueville, Democracy in America 181 (Henry Reeve trans., 1961).

116. See McGinnis, supra note 60 , at 202-03 (discussing social theory that favored centralization of government in the Progressive Era).

117. For a discussion of the effects of a national income tax, see John O. McGinnis \& Michael B. Rappaport, Supermajority Rules as a Constitutional Solution, 40 WM. \& MARY L. REv. 365, 391-92 (1999).

118. See Jay S. Bybee, Ulysses at the Mast: Democracy, Federalism, and the Sirens' Song of the Seventeenth Amendment, 91 Nw. U. L. REv. 500, 557 (1997) (noting that the Seventeenth Amendment greatly increased the independence of senators from state legislatures).

119. See John O. McGinnis, The Original Constitution and Its Decline: A Public Choice Perspective, 21 HaRv. J.L. \& PUB. PoL'y 195, 206 (1997) (describing this process).

120. 317 U.S. 111 (1942).

121. Id. at 128-29.

122. 514 U.S. 549 (1995). 
decades, the Supreme Court held that Congress exceeded its authority under the Commerce Clause in passing a statute, in this case one that prohibited anyone from carrying a gun within five hundred feet of a school. ${ }^{123}$ Dividing Congress's authority under the Commerce Clause into three parts, the five-member Lopez majority acknowledged that Congress has the authority to: first, regulate activities that have a substantial effect on the instrumentalities of interstate commerce; ${ }^{24}$ second, regulate persons or objects in interstate commerce, even if the goal of the regulation concerns intrastate commerce; ${ }^{125}$ and third, regulate activities that have a substantial effect on interstate commerce. ${ }^{126}$ These first two authorities, however, were not available as a justification in Lopez, because the statute did not require the guns it regulated to be connected to interstate instrumentalities or interstate movement. ${ }^{127}$ And for the third authority, Justice Rehnquist noted that the Court's previous cases under the "affecting commerce" rationale had approved regulation of only commercial or economic activities. ${ }^{128}$ Possession of guns near a school was not such an activity, and the Court held that Congress's authority could not extend that far. ${ }^{129}$ The Court also took into account that Congress had made no finding that possession of guns near a school had a substantial effect on commerce. ${ }^{130}$

In Morrison v. United States, ${ }^{131}$ the Court continued to sustain the sphere of state autonomy in noneconomic matters it had begun to carve out in Lopez. ${ }^{132}$ Morrison turned on the constitutionality of the VAWA, which provided a private right of action for victims of gender-related violence against their assailants. ${ }^{133}$ Unlike Lopez, Congress made extensive findings that the failure of states to control gender-related violence harmed the economic prospects of citizens, particularly women, and thereby affected interstate commerce. ${ }^{134}$ Also unlike Lopez, Congress premised its exercise of

123. Id. at 567 .

124. Id. at 558.

125. Id.

126. Id. at 558-59.

127. Id. at 559.

128. Id. at 560 . In response to the claim that carrying guns adversely affected education and thus had an economic effect by depressing the value of human capital, the Court held that to accept such remote effects would give Congress plenary powers, because it would almost always be possible to find some chain of imagined events by which a regulation would have economic consequences. Id. at 56568.

129. Id.

130. Id. at 563 .

131. 529 U.S. $598(2000)$.

132. Id. at 607-13 (reiterating the kind of analysis offered in Lopez).

I33. Violence Against Women Act of 1994, Pub. L. No. 103-322, § 40302, 108 Stat. 1941-1942 (codified as amended at 42 U.S.C. $\S 1398 \mathrm{I}$ ).

I34. See, e.g., H.R. CoNF. ReP. No. I03-711, at 385 (1994). 
authority on Section 5 of the Fourteenth Amendment to assure equal protection of the law as well as on the Commerce Clause. ${ }^{135}$

Relying on Lopez, Chief Justice Rehnquist, writing for the majority, held that the cause of action exceeded Congress's authority. ${ }^{136} \mathrm{He}$ once again noted that the Court had never upheld Congress's authority to regulate noneconomic activity under the Commerce Clause's substantial effects prong. ${ }^{137}$ Without adopting a categorical rule that noneconomic activity could never be so regulated, he held that Congress could not do so here, because the Constitution requires "a distinction between what is truly national and what is truly local."138 He recognized that Morrison differed from Lopez in that Congress had made factual findings, namely that gender-related violence decreased interstate commerce by discouraging citizens from gainful activity. Nevertheless, the Chief Justice specifically rejected the argument that long-term economic effects of crime could provide a basis for showing that the VAWA regulates interstate commerce. Indeed, because all conduct has a ripple effect on the economy when aggregated, if that justification granted legislative power to Congress, it could exercise plenary authority over all activity rather than be limited to its enumerated powers. ${ }^{139}$

Chief Justice Rehnquist also rejected Congress's use of its Section 5 authority under the Fourteenth Amendment to provide VAWA's private cause of action, because the Fourteenth Amendment was designed only to provide remedies against state misconduct. ${ }^{140}$ Chief Justice Rehnquist rejected the claim that the federal private cause of action was the appropriate remedy for the failure of state authorities to prosecute assaults on a genderneutral basis. In his view, the private action was not congruent with the

135. The case arose when Christy Brzonkala used this provision of VAWA to sue Antonio Morrison and James Crawford for sexual assault. Morrison and Crawford challenged the constitutionality of this provision of VAWA, arguing that Congress lacked authority under the Commerce Clause and the Fourteenth Amendment. The Fourth Circuit held, by a divided vote, that Congress did not have authority to enact this provision. See Brzonkala v. Va. Polytechnic \& State Univ., 169 F.3d 820 (4th Cir. 1999) (Luttig, J.), aff'd sub nom. Morrison v. United States, 529 U.S. 598 (2000).

136. Morrison, 529 U.S. at 617-19.

137. Id. at 613. Chief Justice Rehnquist used economic activity and commercial activity synonymously in the opinion.

138. Id. at 617-18.

139. Id. at 614-16. Justice Souter dissented for Stevens, Ginsburg, and Breyer (the same dissenters in Lopez). He noted that Congress had made extensive findings that demonstrated its understanding of the relation between the cause of action and the interstate economy. Id. at 628-35 (Souter, J., dissenting). More generally, he argued that limiting Congress's power to commercial activities was doomed to failure, because the Court could not draw clear lines between the activities it would permit Congress to regulate and those it would not. $I d$. at $640-41$. In his view, the Court was in danger of repeating the near tragedy of the pre-New Deal Court in which the Court became an unpopular political actor by invalidating congressional legislation without clear textual authority. Id. at 642-43.

140. Id. at 619-27. 
purported violation of the Fourteenth Amendment right to equal protection of the law, because it visited no consequences on any state actor. ${ }^{141}$

Morrison deepens the Rehnquist Court's revival of federalism and strengthens its constraints on centralized democratic power in four ways. First, it shows that the Court will not defer to congressional findings about the effect of noneconomic activities on commerce. If the line the Court drew in Lopez were to have real force in reviving federalism, it had to take this step. Otherwise Congress, a body often not inhibited in making grand proclamations on slender evidence, would simply erase the lines of constitutional federalism that the Court had laid down. Moreover, the Court's more intense scrutiny of congressional findings also comports with the increasingly prevalent public choice view that Congress will not make factual findings in anything approaching a neutral or unbiased way, but will tend to find whatever predicates are necessary to advance its members' prospects of reelection. ${ }^{142}$

Second, the Court has prevented Congress from circumventing these restrictions by using Section 5 of the Fourteenth Amendment to regulate private conduct. ${ }^{143}$ This development is also consistent with the public choice insight that special interest groups and symbolic posturing can drive

141. Id. at 624-27. Unlike Justice Souter, Justice Stevens also objected to the Fourteenth Amendment holding because he believed that VAWA's cause of action attempted to cure a state failure to provide equal protection of the laws. Id. at 664-66 (Stevens, J., dissenting). Thus, he suggested (without making a final determination) that Section 5 of the Fourteenth Amendment might authorize rights of actions against private individuals when they help remedy state constitutional misconduct. Id. at 664-65.

142. See Neal Devins, Congressional Factfinding and the Scope of Judicial Review: $A$ Preliminary Analysis, 50 DUKE L.J. 1169 (2001) (suggesting that public choice view of congressional factfinding is accurate).

143. Indeed, for classes that are not suspect classifications under the Fourteenth Amendment, it will be even harder to use Section 5 authority to fashion federal remedial schemes. See Kimel v. Fla. Bd. of Regents, 528 U.S. 62, $82-89$ (2000) (holding that Congress had no power to waive state sovereign immunity under the Age Discrimination in Employment Act in part because age is not a suspect classification and therefore faces only rational basis review). The narrowing of Congress's ability to use Section 5 to protect non-suspect classes is confirmed by the very recent decision in Board of Trustees v. Garrett, 531 U.S. 356 (2001). In Garrett the Court refused to allow Congress to waive sovereign immunity for suits against states under the Americans with Disabilites Act. The Court stated that because the disabled were not a suspect class, Congress could police discrimination under Section 5 only if it built a record showing "irrational discrimination" against the disabled by the states. Therefore, I believe that the Court is making clear that, with respect to non-suspect-classes, it is for the states, not the Congress, to fashion social norms outside the commercial arena so long as they are not "irrational." For a contrary view which predates Garrett, see Ruth Colker, The Section Five Quagmire, 47 UCLA. L. REv. 653, 674-75 (2000) (arguing that Congress still retains broad power under Section 5 with respect to non-suspect classes). While I agree with Colker's assertion that "the language of the Equal Protection Clause suggests that all persons are entitled to make claims involving their right to equal protection" and that "Congress therefore always has a legitimate textual basis for invoking the Equal Protection Clause irrespective of whether a group is entitled to 'suspect class' treatment," the requirement that Congress show that state discrimination is irrational substantially limits its power under Section 5. Id. 
even legislation enacted under the rubric of civil rights. ${ }^{144}$ Thus, the Court has moved decisively to create a sphere of private noneconomic activity untouchable by national regulations, whether through the original enumerated powers or those granted under the reconstruction amendments and subsequent federal legislation.

Third, Morrison makes it clear that even when Congress uses its national power under Section 5 of the Fourteenth Amendment, it must take full account of regional differences. The Court noted with disapproval that, unlike previous national remedies that Congress passed under Section 5 , VAWA was premised on gender discrimination in law enforcement whose existence was shown in relatively few states. ${ }^{145}$ Thus, the Morrison Court suggested that Congress must respect principles of subsidiarity even under the Fourteenth Amendment and apply remedies that are geographically appropriate to the scope of the problem for which it has evidence.

Fourth, the opinion's most important aspect may be the force of its underlying attitude rather than any innovation in doctrine beyond Lopez. Because the law the Court invalidated had so much more resonance with the public than the rather obscure law it struck down in Lopez, the Court demonstrated its serious commitment to federalism. After all, VAWA purported to benefit half the population. Moreover, newspaper editorials across the country and a brief filed by a who's who of legal academics passionately supported its constitutionality. ${ }^{146}$ Indeed, its very title, "Violence Against Women Act," provides a good example of the potency of symbolic legislation that is difficult to oppose in modern democracy. ${ }^{147}$ By

144. For a public choice view of the 1991 civil rights legislation, see, for example, Nelson Lund, Congressional Self-Exemption from the Employment Discrimination Laws: A Rational Choice Analysis of the Civil Rights Act of 1991, 54 LA. L. REv. 1559 (1994).

145. See Morrison, 529 U.S. at 626 (noting that Congress had not found violation in "all States, or even in most states").

146. Brief of Law Professors as Amicus Curiae in Support of Petitioners, United States v. Morrison, 529 U.S. 598 (2000) (Nos. 99-5, 99-29); The High Court Returns, N.Y. TIMEs, Oct. 4, 1999, at $\mathrm{A} 26$ (questioning whether the Court would weaken hasic civil rights).

147. VAWA itself inay be a good example of symbolic legislation. Many of those who testified in favor of VAWA emphasized its symbolic nature. For instance, Sally Goldfarb, representing the National Organization of Woinen, similarly discussed the potential "educational" value of the bill. Violence Against Women Act: Hearing on H.R. 1133 Before the Subcomm. on Civil and Constitutional Rights of the House Comm. on the Judiciary, 100th Cong. (1993) (statement of Sally Goldfarb, Senior Staff Attomey, NOW Legal Defense and Education Fund); see also Sally Goldfarb, The Civil Rights Remedy of the Violence Against Women Act: Legislative History, Policy Implications of Litigation Strategy, 4 J.L. \& PoL'Y 391, 398 (1996) (emphasizing symbolic nature of the legislation). One commentator speculated that "[o]utrage over the Judiciary Committee's treatment of Anita Hill during the summer of 1991 no doubt helped prompt its unanimous backing for this 'pro-women' legislation [the VAWA]." David Frazee, Court TV We'd Like to See: A Plain English Guide to the Violence Against Women Act, Fall 1995, available at http://www.echonyc.com/ onissues/f95vama.html. 
invalidating it, the Justices announced that constitutional federalism is back, so long as the Court's composition remains unchanged. ${ }^{148}$

\section{The Uncertain Shape of Federalism's Revival}

Although the Court is reviving federalism, the exact contours and coherence of its revival are unclear. So far, at least, the Court has invalidated regulation of only noneconomic matters and has not retreated from the New Deal Court's declaration that under the affecting commerce rationale, Congress has essentially plenary powers to regulate any economic matter, regardless of the insubstantiality of the effects on interstate commerce. Indeed, Chief Justice Rehnquist was careful to cite Wickard v. Filburn favorably; the case symbolizes Congress's plenary authority over economic matters. ${ }^{149}$

However, the line that the Court drew between economic and noneconomic matters is not the most consistent with the model of competitive federalism. Recent models of competitive federalism, part of the revival of neoclassical economic models enjoying intellectual influence, suggest that as a matter of efflciency the federal government should regulate only those activities having spillover effects among the states. ${ }^{150}$ Where there are no substantial spillover effects (for instance, in the case of environmental regulation, when jurisdictions do not pollute beyond their bounds), states are likely to provide appropriate levels of regulation as they compete to attract businesses from other jurisdictions. Simply put, such competition allows the cost of regulations to be reflected directly in lost wages. ${ }^{151}$ The connection between regulation and wages creates a dynamic that leads to the optimal level of regulation. It does so by setting the level of regulation at a point where the marginal cost of a unit of regulation equals the marginal benefit for individuals within that jurisdiction. ${ }^{152}$ In other words, employees value public goods such as environmental or safety regulations and will accept lower wages in jurisdictions that possess them. ${ }^{153}$ Thus, as long

148. The Court has also rendered several other important federalism decisions protecting the autonomy of state legislators and state officials from federal power. For discussion of these cases, see infra notes 202-03 and accompanying text.

149. See Morrison, 529 U.S. at 610-11.

150. For an excellent discussion of this thesis, see Revesz, supra note 105; see also Henry N. Butler \& Jonathan N. Macey, Externalities and the Matching Principle: The Case for Reallocating Environmental Regulatory Authority, 14 Y ALE J. ON REG. 23, 25 (1996) (arguing that environmental regulatory authority should be allocated to areas affected by pollution rather than to an area which can harmonize standards). For a fuller discussion of the problem of spillovers in a federal regime, see McGinnis \& Movsesian, supra note 101, at 561-63.

151. For a full discussion of this argument, see Walter Oates \& Robert M. Schwab, Economic Competition Among Jurisdictions: Efficiency Enhancing or Distortion Inducing?, 35 J. PUB. EcoN. 330 (1988). Oates and Schwab assume that individuals cannot move among jurisdictions. Id. at 336.

152. Revesz, supra note 150 , at 1240 .

153. Even if races-to-the-bottom posed real problems, federal regulations might not be the best way to offset them. Because of the public choice problems previously noted, a centralized institution 
as the externalities are confined to individual states, the states rather than the federal government should provide public goods, including appropriate regulatory regimes.

This neoclassical economic argument reflects, however imperfectly, the contours of pre-New Deal Commerce Clause jurisprudence: matters that at that time did not present inuch chance of spillover, like manufacture and labor, were not subject to congressional regulation. ${ }^{154}$ While occasional spillovers in these categories would still have occurred, the Court's line drawing might still be defended as the optimal way for the judiciary to enforce competitive federalism. First, these categories minimized the administrative costs of adjudication: the Court could not readily measure spillovers in individual cascs. ${ }^{155}$ Moreover, these categories may have prevented more political externalities imposed by interest groups through their rent-seeking in centralized deinocracy than is lost in the failure to correct spillovers. ${ }^{156}$

Justice Thomas is trying to revive this older jurisprudence in his concurrence in Lopez (reiterated in Morrison), in which he would simply excise the "affecting commerce" prong of the Commerce Clause. ${ }^{157}$ Under Justice Thomas's view, that strand of Commerce Clause jurisprudence has no foundation in any sphere, thus leaving Congress authority only to regulate the imstrumentalities of interstate commerce and persons or things that cross state lines. ${ }^{158}$ The path suggested by Justice Thomas, but not taken by the Court, would shelter much activity of both an economic and noneconomic kind from federal regulation. ${ }^{159}$

may well be captured by interest groups, and choose a bad standard. See McGinnis \& Movsesian, supra note 101 , at 560 n.278.

154. See Epstein, supra note 63, at 1443-54.

155. The pre-New Deal conception of Congress' authority might still permit federal regulation of particular categories, like interstate pollution, in which externalities cross state lines. Justice Sutherland may have been right when he said that " $[t]$ he relation of employer and employee is a local relation." Carter v. Carter Coal Co., 298 U.S. 238, 308 (1936). However, the relation of a manufacturer to other citizens and businesses on whom he rains pollution may be national.

156. For discussion of the power of special interest groups to extract benefits for themselves at the expense of the public in a centralized democracy, see supra notes 79-82 and accompanying text. Indeed, regulatory regimes liable to be influenced by special interests create negative externalities parallel to those created by productive activity, because the special interests are able to use the government to gain resources for themselves, thereby imposing losses on the diffuse public. Thus, government regulation can create negative externalities as surely as can pollution. For an excellent exploration of this problem in the context of domestic environmental regulation, see Todd J. Zywicki, Environmental Externalities and Political Externalities: The Political Economy of Environmental Regulation and Reform, 73 TUL. L. Rev. 845 (1999). Moreover, unlike producers who impose externalities, special interests trying to gam resources from government do not produce useful goods and services in the process!

157. United States v. Lopez, 514 U.S. 549, 584 (1995) (Thomas, J., concurring); Morrison, 529 U.S. at 627-28 (Thomas, J., concurring).

158. Lopez, 514 U.S. at 596-98 (Thomas, J., concurring).

159. Given that one purpose of the competitive federalism model is to restrain special interests, see McGinnis, supra note 60, another critique of the line drawn by the Lopez majority is that, because 
The distinction between economic and noneconomic matters embraced by the Rehnquist Court may not only include regulatory matters still best left to the states, but may also exclude from Congress's jurisdiction matters that are best regulated centrally. Consider, for instance, a matter that the Supreme Court narrowly avoided addressing last year: can Congress regulate wetlands wholly within a single state on the theory that these wetlands are needed to sustain wildlife? ${ }^{160}$ Such wetlands may well create spillovers of the kind that should be centrally regulated: if a state fails to protect them, it is harming wildlife both inside and outside its borders. ${ }^{161}$ But these kinds of spillovers do not necessarily affect any economic enterprise and thus may not be within the affecting commerce prong of the Commerce Clause, as construed by Lopez and Morrison. To be sure, the Morrison majority left itself room to allow congressional regulation in these areas by suggesting that its refusal to permit the regulation of noneconomic matters is not categorical, but it has offered no rationale as yet for that concession. ${ }^{162}$

If the distinction the Court draws between economic and noneconomic matters has some flaws from the standpoint of fully implementing a jurisprudence of decentralization, what is driving it? First, the Court cannot return to a more rigorous model of competitive federalism, because there is simply too much obstructing precedent. Moreover, the modern federal administrative state is founded on these precedents. As Robert Bork, hardly a friend of New Deal jurisprudence, has stated, to overturn the precedent on Congress's regulatory authority over economic matters would be "to overturn much of modern governance and plunge us into chaos."163

Second, ousting the federal government from jurisdiction over noneconomic matters is less controversial, thus creating fewer political risks for the Supreme Court. Because economic legislation addresses the allocation of societal resources, disputes over such decisions are likely to be

of the possibility of concentrated gains, special interests are more powerful in regulatory matters than in noneconomic matters, like criminal law. Therefore, the case for competitive federalism may be even stronger in economic matters, yet another reason for suggesting that the distinction between economic and noneconomic matters may be unstable.

160. The Supreme Court avoided this issue by narrowly construing, in light of the constitutional problems that would otherwise have been presented, a statute that lower courts interpreted to give the Army Corps of Engineers the authority to regulate wetlands where migratory birds rested and fed. See Solid Waste Agency of Northern Cook County v. United States Army Corps of Eng'rs, 531 U.S. 159 (2001); see also Gibbs v. Babbit, 214 F.3d 483 (4th Cir. 2000) (Wilkinson, C.J.) (holding that Congress had authority under the Commerce Clause to prohibit a landowner from trapping fox on his own land).

161. But see Jonathan H. Adler, The Ducks Stop Here? The Environmental Challenge to Federalism, 9 Sup. ECON. REv. 205, 231-33 (2001) (arguing that spillovers ainong states were not present in the wetlands situation that the federal government sought to regulate).

162. See Morrison, 529 U.S. at 613 (refusing to adopt "categorical rule" that noncommercial matters could not be regulated under the "affecting commerce" rationale of the Commerce Clause).

163. Robert H. Bork, The Tempting of america: The Political Seduction of the law 159 (1990). 
particularly fierce and endanger the Court's reputation for political neutrality. In striking down federal labor regulation, the Court, even if correct as a matter of competitive federalism, was entering a dispute between capital and labor that precipitated a constitutional crisis. ${ }^{164}$ In contrast, noneconomic legislation focuses less on resource allocation. Relatively few people are going to march to the barricades over the gun carrying law at issue $\mathrm{m}$ Lopez or even the gender discrimination law at issue $\mathrm{m}$ Morrison. ${ }^{165}$ Thus, a fundamental explanation for the Court's creation of space for noneconomic civic society is that it is simply an easier political task.

Thus, what Lopez and Morrison have generated is competition in governance $\mathrm{m}$ a certain sphere of noneconomic matters, such as criminal law and human rights. In human rights, the incorporation doctrine has made the sphere for experimentation smaller, because the Court itself has guaranteed a core of rights through its interpretation of the Fourteenth Amendment. ${ }^{166}$ But the Court's new jurisprudence does not permit Congress to expand these rights beyond the boundaries of the national settlement the Court has itself set. ${ }^{167}$ Outside of these Court-established rights, it is the states rather than the federal government who are free to experiment with different bundles of rights, as well as different tort and criminal law mechanisms to enforce them. ${ }^{163}$

The refusal to allow the federal government to create rights beyond mcorporation creates a substantial space for federalism to work as a dis-

164. See Sarah Barringer Gordon, The Creation of a Usable Judicial Past: Max Lerner, Class Conflict, and the Propagation of Judicial Titans, 70 N.Y.U. L. REv. 622, 634-35 (1995) (canvassing the view that pre-1937 New Deal constitutional decision precipitated a constitutional crisis whose principal impetus was the need to reconcile democracy with new forms of industrial capitalism).

165. One exception to public acquiescence might be a Court decision that struck down federal regulation of abortion on the grounds that the regulation exceeded Congress's enumerated powers. Nevertheless, even the issue of abortion does not have the capacity to create substantial civil unrest that issues of economic allocation do.

166. Currently, national rights are also established through the fundamental rights jurisprudence of the Supreme Court. For criticism of fundamental rights jurisprudence as incompatible with a jurisprudence of decentralization and spontaneous order, see infra notes 424-33 and accompanying text.

167. Already Congress cannot expand the content of rights through Section 5 of the Fourteenth Amendment. See City of Boenue v. Flores, 521 U.S. 507 (1997) (holding the Congress has no substantive, nonremedial power to change the content of rights guaranteed by the Fourteenth Amendment). For discussion of the way in which Morrison limits Section 5's remedial power as a substitute for the Commerce Clause, see supra note 135 and accompanying text.

168. Thus, I strongly disagree with those who question whether it makes any "sense" to "protect discrete areas of social life from federal interference" now that Congress has plenary authority to regulate economic matters. See Robert C. Post \& Reva B. Siegel, Equal Protection by Law: Federal Antidiscrimination Legislation After Morrison and Kimel, I10 YALE L.J. 441,485 (2000). One may reject the Court's approach, but it is entirely coherent as a matter of both text and social policy to carve out a sphere for the states in experimentation with civil rights beyond a core bnndle. Professors Post and Siegel never discuss the systematic public choice problems with centralized legislation and this neglect blinds them to the defects of national legislation and the possibility of a continumg role for constitutional federalism. 
covery machine. Outside a core set of rights, such as freedom of speech and religion, basic criminal procedure, and guarantees of nondiscrimination by the states, it is difficult to know what set of rights is appropriate for a society. As Professor Nelson Lund has observed, rights implicate one of the oldest issues of republican government: the tension between liberty and license. ${ }^{169} \mathrm{It}$ is hard to discern the proper mix of rights that both optimally protects liberties and yet does not permit liberties to degenerate into the license that ultimately undermines all liberties. ${ }^{170}$ Because of the power of interest groups and the tendency toward symbolic, feel-good legislation, ${ }^{171}$ the process of centralized democracy seems unlikely to approximate the proper mix of rights.

Thus, as a matter of political economy, it may make more sense for the states instead to compete in determining the appropriate mix of rights for their citizens above a minimum threshold. ${ }^{172}$ States could then make such decisions as whether the proximity of a school should curtail the right to carry a gun, the federal law at issue in Lopez. ${ }^{173}$ At a fundamental level, it is unclear why the law on this matter need be the same for rural Montana and urban New York. It also may make sense to allow the states to determine how most effectively to enforce rights of it citizens through tort and

169. See, e.g., Nelson Lund, Federalism and Civil Liberties, 45 U. KAN. L. REv. 1045, 1060-64 (1997) (suggesting that centralizing civil rights enforcement through the incorporation doctrine has made it more difficult to experiment for the appropriate balance of rights).

170. Id.

171. Recent examples of federal feel-good legislation includes, for instance, a federal carjacking law. See Anti-Car Theft Act of 1992, 18 U.S.C. $\$ 2119$ (1994 \& Supp. 1996). States are perfectly capable of punishing carjackings that take place within their jurisdictions and, in fact, they severely punish such crimes. There is no reason for a federal law. Neal Devins has an excellent discussion of the growing tendency of Congress to pass politically popular legislation at the national level for reasons of symbolism rather than as a solution to a national problem:

[V]oters expect lawmakers to support politically popular legislation, not block it for a principle as abstract as Congress's failure to show-through factfinding-that the measure addresses a national problem. "A lawmaker who voted against the national Megan's law or the national car-jacking law, for example, would almost certainly be characterized as being soft on crime in her opponent's next thirty-second sound bite."

Devins, supra note 142, at 1195 (footnotes omitted).

172. Another case that may fit into the jurisdictional competition model is Saenz v. Roe, 526 U.S. 489 (1999). There the Court employed the Privilege or Immunities Clause to strike down a state residency requirement for welfare benefits. $I d$. at $510-11$. While this may seem a throwback to Warren Court activism on behalf of the poor, it could also be understood as facilitating the ability of citizens to cross state lines. Such ease of movement makes it easier for jurisdictional competition to work on noneconomic rights provided by states and thus enhances the competition in noneconomic social norms that is the hallmark of the Rehnquist Court. On the other hand, it makes competition in welfare rights harder because states experimenting with higher welfare rights may trigger immigration and a burden on the public fisc.

173. See Lund, supra note 169 , at 1067 (offering legislation relating to guns as an example of a matter that may profit from interstate competition). Professor Lund in his article uses competitive federalism considerations to question the wisdom of incorporation as a policy matter. Id. at 1071. 1 discuss below the reasons that the Court is unlikely to disturb such central precedents even while pursuing a jurisprudence of decentralization and spontaneous order. See infra note 460 and accompanying text. 
criminal law, the matters at issue in Morrison. Once again, the national government can enforce a threshold level of enforcement by authorizing actions against state officials for enforcement failures. ${ }^{174}$ This decentralized approach for enforcement also allows scope for experimentation. ${ }^{175}$

Moreover, by restoring broad decision-making power to the states and localities, the Court is reviving the local civic engagement of which Tocqueville spoke. ${ }^{176}$ Civic responsibility makes citizens more capable of participating responsibly in the larger polity. Thus, the Court is responding to the danger of mass apathy and interest group politics by making state citizens more responsible arbiters of their own affairs. ${ }^{177}$ As Tocqueville hoped, this "republican spirit" nnay then be better applied to the "country at large." 178

174. Morrison did not bar the federal government from authorizing suits against state officials. Indeed, its objection to the private suits at issue was that they did not "visit consequences on any state actor." See supra notes $140-41$ and accompanying text.

175. Some might argue that the Court's decision in Bush v.Gore, 531 U.S. 98 (2000), discredits its claim to be a Court seriously interested in reviving federalism because the majority used federal law to override a state supreme court's construction of its own election laws. But, whatever the merits of that decision, it does not seriously undermine the role of federalism as a discovery machine for social norms. The question of whether physically identical ballots must be counted identically, which the Court resolved under the Equal Protection Clause, does nothing to expand Congress' authority to craft social norms about primary standards of conduct, like carrying a gun near a school, or the enforcement of such norms though tort or criminal law. The Article II question in the case, whether the Florida Court can change its state legislature's law after the election, is a sui generis question about the Constitution's rule concerning the appointment of electors. This mle is unrelated to general federalism issues. See U.S. Const. art. II, $\$ 1$, cl. 2 ("Each State shall appoint, in such Manner as the Legislature thereof shall direct, a Number of Electors ...."). Critics have also argued that the Court's remedy was contrary to federalism because the Court terminated the state counting of votes rather than remanding the case for a count under constitutional principles. But as Nelson Lund has persuasively argued, the Court was following the Florida Supreme Court's interpretation of Florida election law and leaving it open to that Court to change its interpretation on remand, should it have been asked to do so. See Nelson Lund, The Unbearable Rightness of Bush v. Gore, 24 CARDOzo L. REv. (forthcoming 2002). In any event, Bush v. Gore concemed a putative constitutional crisis and not the construction of constitutive structures to generate beneficial social norms on a day-to-day basis, which is the subject of this Article.

176. See supra notes 107-08 and accompanying text.

177. The best defense in political theory of the Rehnquist Court's immunity decisions-those that bar suits against the states under the Eleventh Amendment-is that a certain degree of "dignity" and "financial integrity" helps the states function as vehicles of civic engagement. See Alden v. Maine, 527 U.S. 706, 749-51 (1999). Nevertheless, these immunity decisions do not necessarily contribute directly to a inore decentralized setting of social norms because the federal government can still largely set norms in these areas by directly regulating private actors rather than the states. Immunity decisions, whatever their value, are not as important in reviving a jurisprudence of decentralization and spontaneous order as decisions, like Lopez and Morrison, restricting the reach of the federal government's power. Moreover, unlike decisions construing the Commerce Clause, they are perhaps not well-grounded in the text of the Constitution. See John F. Duffy, Seminole Tribe v. Florida: Faithful Federalism or Right-Wing Brennanism, available at http://www.fed-soc.org/ Publications/practicegroupnewsletters/federalism/fd010104.htm (last visited Feb. 15, 2002).

178. 1 DEMOCRACY IN AMERICA, supra note 21, at 181. 


\section{The Future of Federalism as a Discovery Machine}

While Lopez was an important case for Commerce Clause doctrine, its long-term efficacy in protecting state autonomy is less than clear. For instance, Lopez would not stop Congress from imposing a national rule prohibiting the carrying of guns within 1000 feet of a school, as long as Congress simply re-enacted the law as a condition on state receipt of federal criminal justice funding. Indeed, it has enacted other firearm provisions relating to education through such a procedure. ${ }^{179}$ Despite the Rehnquist Court's Commerce Clause jurisprudence, Congress can use its conditional spending power to pressure states to enact a cause of action that would precisely track the federal cause of action invalidated in Morrison.

Under current doctrine, Congress clearly has the authority to accomplish almost any objective it wants under its conditional spending authority. In South Dakota v. Dole, a case concerning the social norm of the drinking age, the Court required Congress to meet three requirements to impose conditions on grants of federal funds. ${ }^{180}$ Only one, however, has any potential bite: conditions must be related "to the federal interest in particular national projects or programs." ${ }^{" 181}$ But the Court did not identify any case in which it had ever struck down spending on this ground. ${ }^{182}$ Since the New Deal, the Court has never invalidated any congressionally imposed condition on the states pursuant to its spending authority. Moreover, given the large amount of federal spending in almost every area of civic life, it is almost inconceivable that Congress cannot find a hook on which to hang a regulation.

If the Spending Clause remains as plenary as it appears, the Court's revival of the enumerated powers jurisprudence may be insufficient to recreate federalism as a discovery machine. To accomplish this goal, the Court could attempt to transform its conditional spending clause jurisprudence to better reflect the federalist values of Lopez. However, such a jurisprudence would face difficulties of precedent and practicality. First, the precedent of South Dakota v. Dole provides Congress with ample

179. See, e.g., 20 U.S.C. $\$ 8921$ (1994) (requiring states receiving federal educational funds to establish a program to expel students carrying guns to school). There may be other ways to circumvent the federalism reinforcing effects of Lopez. For instance, given that gun parts are often made in different jurisdictions, Congress might use the interstate jurisdictional hook of multistate assembly to prohibit such guns from being carried near schools.

180. 483 U.S. 203,207 (1987). The first condition was that "exercise of the spending power must be in pursuit of 'the general welfare." Id. But the Court is so deferential to Congress' judgment in this regard that it has itself questioned whether it is judicially enforceable. Id. at $207 \& \mathrm{n} .2$ (quoting Buckley v. Valeo, 424 U.S. 1, 90-91 (1976)). The second condition the Court requires is that Congress state any condition on the states' receipt of federal funds "unambiguously," but this requirement simply forces Congress to be clear and does not limit its uitimate authority. Id. at 207.

181. Id. at 207.

182. Lynn A. Baker, Conditional Federal Spending After Lopez, 95 Colum. L. Rev. 1911, 1930 (1995). 
discretion in the spending arena and was written by Chief Justice Rehnquist himself with only Justices O'Connor and Brennan dissenting. ${ }^{183}$ Because of this precedent, otherwise plausible revisions of conditional spending doctrine may face an uphill fight. ${ }^{184}$ For instance, Lynn Baker has helpfully suggested that federal spending conditions be limited to "reimbursement conditions" that specify the purpose for which states are to spend federal funds, thereby limiting regulatory conditions that seek to regulate state activity outside the scope of the enumerated powers. ${ }^{185} \mathrm{But}$ such a test would have reversed the outcome in Dole because there the condition did not provide specifications for building highways but sought to regulate teenage drinking. ${ }^{186}$

Without overruling Dole, however, the Court might also provide renerved bite to another requirement mentioned there (albeit not as part of its principal test) and reflected in earlier cases, that the state not be coerced into accepting the condition through the federal spending. ${ }^{187}$ The coercion requirement may naturally have more scope now that the Court has decided that the Congress lacks the power to regulate some areas under the Commerce Clause. ${ }^{188}$ Consider in this regard the new education bill. ${ }^{189}$ Many of the conditions Congress imposed on state schools as a result of the education bill are not directly related to commerce and therefore under Lopez could not have been imposed directly. But the money provided to the states will be very substantial and the political imperative of improving education is overwhelming - far stronger than building highways. ${ }^{190}$ Given the political reality that no governor of a state could refuse these funds, the

183. 483 U.S. at 212 (Brennan, J. \& O'Connor, J., dissenting). The Court may also be reluctant to abandon its settled law in this area because it would potentially upset expectations nnder the many conditional spending programs that Congress has previously enacted.

184. See Thomas R. McCoy \& Barry Friedman, Conditional Spending: Federalism's Trojan Horse, 1998 Sur. CT. Rev. 85, 123 (showing that the germaneness requirement in Dole is a precedent empowering Congress to impose a wide range of spending conditions).

185. Baker, supra note 182, at 1962-63.

186. Moreover, this reform proposal may run into some difficulties in distinguishing "reimbursement conditions" from "regulatory conditions." See Daniel J. Meltzer, The Seminole Decision and State Sovereign Immunity, 1996 SUP. CT. REv. 1, 51, 54 n.250 (posing difficult hypothetical questions about "reimbursement spending" and "regulatory spending," such as: "Does a federal requirement that grants to a state university for biological research not to be used to subsidize action infringing valid patents specify how funds shall be spent or purchase a regulatory objective?").

187. Dole, 483 U.S. at 211 ("Our decisions have recognized that in some circumstances the financial inducement offered by Congress imght be so coercive as to pass the point at which 'pressure turns into compulsion."') (quoting Stewart Machine Co. v. Davis, 301 U.S. 548, 590 (1986)).

188. See supra notes $121-48$ and accoinpanying text.

189. No Child Left Behind Act of 2001, Pub. L. No. 107-110 (Jan.8, 2002).

190. See Charles Cook, 24 WASH. Q. 189, 190 (2001) ("every poll shows that education has been and remains a top [political] priority for most Americans"). 
Court could conceivably hold this condition coercive in the exceedingly improbable event that any state would be willing to challenge it. ${ }^{191}$

Furthermore, the ease with which Congress uses the conditional spending power and states' readiness to acquiesce may suggest even more serious problems for the establishment of constitutional federalism as a discovery machine in modern America. Constitutive structures for protecting spontaneous order must enjoy popular support for the Court to invalidate legislation that has at least a superficial or symbolic appeal. Federalism worked as a constitutive mechanism in the nineteenth century precisely because individuals had the fierce attachments to states that gave the Court support for defending state autonomy even against otherwise popular causes. ${ }^{192}$ James Madison himself recognized that these attachments were central to preserving federalism. To the Constitution's opponents, who feared that the federal government would swallow the states through consolidation, he declared:

They must be told that the ultimate authority... resides in the people alone, and that it will not depend merely on the comparative ambition or address of the different governments, whether either, or which of them, will be able to enlarge its sphere of jurisdiction at the expense of the other. Truth, no less than decency, requires that the event in every case should be supposed to depend on the sentiments and sanction of their common constituents. ${ }^{193}$

Madison was sanguine that state autonomy would flourish because these attachments were strong. As he stated in The Federalist, "[m]any considerations ... seem to place it beyond doubt that the first and most natural attachment of the people will be to the governments of their respective States." 194

Today, however, those attachments appear to have dissipated. Many citizens no longer feel a strong sense for their state's identity or autonomy from the federal government. ${ }^{195}$ One explanation for this shift credits the federal government's increased power. States no longer have the political salience they did when Congress's powers were more limited. ${ }^{196}$ Some

191. One compelling argument against a jurisprudence that breathes life into the coercion requirement would be the lack of bright lines available to distinguish a state that was coerced and one that was merely incentivized within the appropriate bounds of inducement.

192. See, e.g., Peter J. Spiro, The Citizenship Dilemma, 51 Stan. L. Rev. 597, 618 (1999) (book review) (noting the slow movement in the nineteenth century "from state to nation as the dominant locus of individual loyalties").

193. The Federalist No. 46, at 294 (James Madison) (Clinton Rossiter ed., 1961).

194. Id.

195. See Maurice J. Holland, Prospects for Federalism, 6 Harv. J.L. \& Publ. Pol'y 31, 37 (1982) ("The strong sense of cultural identity with one's state's characteristic of nineteenth century Americans is moribund, a permanent victim of social mobility and the pervasive influence of the national media among other factors.").

196. See Robert E. Nagel, Federalism as a Fundamental Value: National League of Cities in Perspective, 1981 SuP. CT. REv. 81, 100-08 (suggesting that National League of Cities v. Usery, 426 
commentators who favor the revival of federalism have embraced this explanation, suggesting that states need "substantive regulatory authority for state governments to remain a meaningful presence in the consciousness of their citizens." 197 But even if the political decline of the states and judicial decisions that abetted them were the only causes of this phenomenon, granting states new spheres of influence may not necessarily revive the popular attachment to states federalism requires. Emotions that have died cannot be so easily rekindled.

In any event, judicial decisions are not the primary cause of the decline of attachment to states. The huge decrease in transportation and information costs in the twentieth century has created a mass culture that has wholly extirpated state differences and even substantially tempered regional ones. ${ }^{198}$ It is more difficult to feel strongly about state rights if you live in New Jersey and work in New York for a company with its headquarters in Texas.

The dimmution of individuals' attachments to their states does not necessarily prevent devolution of policy to the states in specific areas. For example, Congress largely has returned welfare policy back to the states. ${ }^{199}$ But such devolutions of power occur only at the expense of central authority. The firm lines necessary for competitive federalism to work are nnder constant threat from the shifting of transient policy imperatives, such as a crisis in education or war on drugs, to name just a few contemporary issues. ${ }^{200}$ Ultimately, a constitutional structure for protecting spontaneous order must itself be based on passions strong enough to counterbalance the erosive effect of passions spurred by national policy debates. A successful constitutional federalism must be a federalism of the heart rather than of the intellect.

It is true that the Court has some ability to mute the effects of these changes and its attempts to do so explain some of its other prominent

U.S. 833 (1976), should be understood as an attempt to restore authority and prestige to states so they could effectively function in a federal system).

197. Emest A. Young, State Sovereign Immunity and the Future of Federalism, 1999 Sur. CT. REV. 1,45 .

198. For the role of changing information and transportation costs in transforming political structures, see Cathleen C. Herasimchuk, The New Federalism: Judicial Legislation by the Texas Court of Criminal Appeals?, 68 TEx. L. REv. 1481, 1483 (1990) ("Increasing mobility, instantaneous national communication networks, continued momentum toward national economic, educational, and legal standards, and the emergence of a national culture suggest that American values are less state-oriented."); John O. McGinnis, The Decline of the Western Nation State and the Rise of the Regime of International Federalism, 18 CARDOzo L. REv. 903, 909 (1996).

199. See Helen Hershkoff, Welfare Devolution and State Constitutions, 67 FordHam L. Rev. 1403, 1403-04 (1999) (describing devolution of the responsibility for welfare from the federal government to the states).

200. See William P. Marshall, American Political Culture and the Fallures of Process Federalism, 22 HARv. J. L. \& PUB. PoL'Y 139, 145 (1998) (suggesting that it is difficult for a Congressperson to vote against otherwise popular policies on federalism grounds). 
federalism decisions. What Tocqueville called the "most prominent evil of all federal systems"201-their complexity-becomes a particular threat to accountability when the citizens lose an intuitive appreciation of federalism that helps them understand these complexities. Beginning with New York v. United States, the Court has, at least, tried to make it harder for public officials to blend federal and state powers. ${ }^{202}$ It has made lines of authority clear by refusing to permit the federal government to "commandeer" state processes to pursue objectives established by the federal government, regardless of whether state officials consent.

But judicial doctrines can do only so much to arrest the nationalizing forces of technology. Without a renewal of citizens' emotional attachments to their states, it is unclear to what extent federalism can be revived as a discovery machine generating superior regulations and social norms. If centralized democracy has inherent flaws because of interest groups and federalism has inherent infirmities because of the loss of local attachments, the Court has reason to consider whether the Constitution protects other discovery machines, whose workings may be more compatible with the contemporary predispositions of our citizens. ${ }^{203}$

\section{III}

\section{Reviving Mediating Institutions Through Freedom of Association}

It is not surprising that a jurisprudence seeking to revive spontaneous order would also focus on nongovernmental discovery machines (private associations) to supplement federalism. Of course, for these private

201. See 1 Democracy in America, supra note 21, at 166.

202. 505 U.S. 144 (1992). See also Printz v. United States, 521 U.S. 898 (1997) (refusing to permit the federal government to command state and local officials to conduct background checks as defined by federal law).

203. One anomaly of constitutional federalism today is the Court's promiscuous use of "conflict" and "occupation of the field" pre-emption, the doctrine that permits it to invalidate state laws even when Congress has not directly done so. For a discussion of this anomaly and criticism of the majority's holding in Geier v. American Honda Motor Co., 529 U.S. 861 (2000), on federalism grounds, see Alexander K. Haas, Note, Chipping Away at State Tort Remedies Through Pre-emption Jurisprudence: Geier v. American Honda Motor Corp., 89 CALIF. L. Rev. 1927 (2001). In fact, the states lost the four major pre-emption cases of the last term (Crosby v. Nat'l Foreign Trade Council, 530 U.S. 363 (2000); Geier, 529 U.S. at 861; Norfolk S. Ry. Co. v. Shanklin, 529 U.S. 344 (2000); United States v. Locke, 529 U.S. 89 (2000)). Only in Locke and Shanklin did the federal statutes even plausibly pre-empt state law. If the Court is willing to strike down federal statutes to protect a sphere of state autonomy, a fortiori it should require Congress to speak plainly before disturbing state law. Justice Stevens, hardly the strongest general proponent of constitutional federalism on the Court, began his dissent in a pre-emption case, Geier, by noting that the pre-emption issue was a "case about federalism" in order to highlight the incongruity between the Court's jurisprudence of constitutional federalism and its jurisprudence of pre-emption. 529 U.S. at 887 (Stevens, J., dissenting) (quoting Coleman v. Thomas, 501 U.S. 722, 726 (1991)). Given the strength of the Court's commitment to constitutional federalism and Justice Stevens's shaming attacks, I would expect the internal logic of the Court's preference for decentralized government ultimately to influence the shape of its pre-emption doctrine. Even a federalism of the intellect that is not strong enough to resist congressional directives can force Congress to be accountable when it exercises its plenary power. 
associations to act as discovery machines without federal or state governmental supervision, they must not create substantial negative externalities of the kind that government needs to address. To put it in a slightly more expansive way, for a category of discovery facilitating activities to receive constitutional protection from government regulation, the category's negative externalities must be outweighed by the negative political externalities caused by government regulation of that category of activities. ${ }^{204}$

Because the harms caused by government regulation of speech outweigh the harm speech itself causes, the First Amendment is a logical focus for protecting a category of activity that promotes the discovery of social norms. Generally, speech rarely results in physical harm or other strong negative externalities. ${ }^{205}$ In fact, information production usually generates positive externalities. Despite the absence of negative externalities and the presence of positive externalities, government officials have a natural tendency to suppress speech antithetical to their interests because information relating to politics and culture can threaten government hierarchies both by rearranging coalitions and revealing facts that will prompt political action. ${ }^{206}$ Accordingly, the First Amendment restricts government officials, both state and federal, from regulating speech absent a compelling public interest. ${ }^{207}$

One of speech regulation's harms is to increase the difficulty for beneficial social norms to arise from the millions of daily judgments (be they condemnations, encomiums, or comments somewhere in between) that citizens freely deliver concerning the personal behavior, tendencies, and character of both government officials and private actors. ${ }^{208}$ Free speech

204. Richard Posner provides a similar defense of free speech in Free Speech in an Economic Perspective, 20 SufFolk U. L. REv. 1 (1986).

205. When speech does threaten imminent dangers, it can be regulated. See Brandenburg v. Ohio, 395 U.S. 444, 447 (1969) (permitting government to suppress speech if the speech is "directed to inciting or producing imminent lawless action and is likely to incite or produce such action").

206. See John O. McGinnis, The Once and Future Property-Based Vision of the First Amendment, 63 U. CHI. L. REv. 49, 76 (1996) (suggesting that the danger of government suppression was the reason the Frauners singled out property rights in information production for more protection than property rights in material production).

207. One reason that expanding a national right of information transmission is less incoinpatible with federalism than other national rights is that information transmission helps jurisdictional coinpetition by making actors aware of alternatives in different jurisdictions.

208. Beneficial social norms are likely to arise from the free flow of information in a social order that otherwise protects markets and punishes violence and fraud, because individuals will have an interest in gaining a reputation for providing accurate and useful information in order to seem more trustworthy and effective, two characteristics that markets reward. See McGinnis, supra note 206, at 129-32 (showing low-cost information can ease the enforcement of contracts). For a more pessimistic view on the efficiency of social norms, see Eric A. Posner, Law, Economics, and Inefficient Norms, 144 U. PA. L. REv. 1697 (1996) (offering reasons that spontaneous order in social norms may be inefficient). The debate over the overall efficiency of social norms cannot be resolved here. My point in this Article is not to defend the claim that spontaneous social norms are always efficient but to show how Supreme Court jurisprudence is responding to a growing sense that spontaneous order has greater advantages vis-à-vis government control than previously recognized. 
helps form social norms through the incremental accumulation of millions of individual judgments. In this way, free speech acts as an important discovery machine whose social contributions are valuable independent of its direct contributions to democratic politics. Indeed, because social norms generated by free expression restrain citizens, government coercion, the primary subject of politics, becomes less necessary. ${ }^{209}$

Because private associations provide focus and discipline for individual social judgments and amplify their power, they act as the engine of this discovery machine. ${ }^{210}$ The move from protecting individual expression under the Free Speech Clause to protecting collective expression, which is the essence of the right of expressive association, is a modest one. As Michael Paulsen has correctly observed, if groups have the right to speak under the First Amendment, as they plainly $\mathrm{do}^{211}$ they require "freedom of autonomous message formation and delivery by the group" including "the power to define who will constitute the group that forms the message and the speakers who will express it on behalf of the group."212 The power to define who may deliver messages logically includes the power to exclude those parties whose identity is incompatible with the message.

This view also has roots in a comprehensive theory of the First Amendment. I have previously argued that the Free Speech Clause protects information transmitted absolutely subject to only the limitations that the speaker cannot transmit information to take the life or property of another through force or fraud. ${ }^{213}$ In contrast, the Free Press Clause has a different regime protecting the use of material property to transmit information, including expressive conduct. ${ }^{214}$ The Press Clause permits only generally applicable rules to be applied to the press and other material conduits of information. Freedom of expressive association-the group formation of message-falls into the first category of protected information production because it does not depend on the use of the material world, only the relation of one individual to a group. It thus should be free from regulation subject to the usual Lockean and common law exceptions of force and fraud.

209. McGinnis, supra 206, at 130-31 (seeing norms created by expression as altenative to centralized government coercion).

210. See Richard W. Garnett, The Story of Henry Adams's Soul: Education and Expression of Associations, 85 MiNN. L. Rev. 1841, 1852 (2001) (discussing amplification provided by civil associations).

211. The First Amendment includes a collective right, expressly "the right of the people peaceably to assemble, and to petition the Government for a redress of grievances." U.S. CONST. amend. I.

212. See Michael Stokcs Paulsen, Scouts, Families and Schools, 85 MinN. L. Rev. I9I7, 1922 (2001); cf. David Cole, Hanging with the Wrong Crowd: Of Gangs, Terrorists, and the Right of Association, I999 SUP. CT. REv. 203, 228-29 (showing more generally that the right of association has historical and normative support in the First Amendment).

213. See McGinnis, supra 206, at 85-86.

214. Id. at $9 \mathrm{I}$ (describing that conduct includes the use of one's body, a material objective, to transmit information). 
Tocqueville's view of the principle of free association as constitutive of American society was also predicated on the ability of such associations to generate a complex and beneficial network of social norns. ${ }^{215}$ Tocqueville analogized the circulation of opinions that associations support to economic markets. ${ }^{216}$ Like the prices in economic markets, the judgments of associations vary with time, place, and context and thus operate with more flexibility than the decrees of centralized governmental institutions. Preserving the autonomy of these civil associations helps sustain the subtleties and complexities of this spontaneous order, which in turn inproves the behavior and character of individuals without the intervention of the centralized state. ${ }^{217}$ In this way, civil associations help constitute First Amendment discovery machines for social values by sifting and articulating millions of individual assessments, much as a competitive economic market does, thereby allowing various social norms to compete for prominence. ${ }^{218}$

In the past decade the Rehnquist Court has strengthened the role of civil associations im three ways, which this Part discusses in turn. First, and most importantly, it has expanded the right of expressive association, making clear that noncommercial civil associations have a right to exclude members whose identity interferes with their message's formation; the Court has deferred to the association regarding the message's content. Second, the Court has analogized a civic organization's right of expressive association with a political organization's right of political association, underscoring that courts should not treat civil associations as second-class organizations for First Amendment purposes. On this view, civil associations should enjoy similar rights to select members that facilitate rather

215. Tocqueville said that the United States was the country "in the world where the continual exercise of the right of association has been introduced into civil life and where all the advantages which civilization can confer are procured by means of it." See 2 DEMOCRACY IN AMERICA, supra note 21 , at 115 .

216. See 2 DEMOCRACY IN AMERICA, supra note 21, at 109 ("A govemment can no more be competent to keep alive and to renew the circulation of opinions and feelings among a great people than to manage all the speculations of productive industry.").

217. See Robert C. Ellickson, Law and Economics Discovers Social Norms, 27 J. LEGAL STUD. 537,540 (1998). Elitickson suggested that

[m] uch of the glue of a society comes not from law enforcement ... but rather from the informal enforcement of social mores by acquaintances, bystanders, trading partners, and others. These unofficial enforcers use punishments such as negative gossip and ostracism to discipline malefactors and bounties such as esteem and enhanced trading opportunities to Id. reward the worthy.

218. One criticism is that the right of expressive association permits individuals to be excluded from circles where they would reap benefits. But, as we discnss later, if an association excludes individuals who will both benefit the association and benefit from it, they give incentives to such individuals to form other competing associations. See infra note 256 and accompanying text. Like other forms of spontaneous order, associations contain a self-correcting mechanism to keep them on the track of social beneficence, so long as the government protects the right of others to exit and form competing associations. 
than undercut the social norms they advance. Third, the Court has permitted at least some government institutions to provide funding for civil associations so long as they do so on a viewpoint neutral basis. This ruling provides constitutional space for the political branches to facilitate the revival of civil associations.

\section{A. Expanding the Right of Expressive Association}

One important test of whether a Court is following a jurisprudence of advancing spontaneous order is its solicitude for the autonomy of civil associations that do not provide direct inputs into the political process. The Rehnquist Court has begun to protect this autonomy right to a far greater extent than the Warren and Burger Courts. To be sure, the Warren and Burger Courts offered protection for the autonomy of some associations, but these associations provided political inputs or were intimate associations, such as the family. ${ }^{219}$ The justification for protecting their autonomy flowed from the twin paradigms of perfecting social democracy and protecting the autonomy of an intimate sphere within that democracy.

The Burger Court was not a staunch guardian of the rights of mediating institutions. Thus, in Roberts v. United States Jaycees, ${ }^{220}$ the Court upheld the application of Minnesota's gender antidiscrimination law to the Jaycees against the complaint that admitting women would change an organization's "philosophical cast."221 In an opinion by Justice Brennan, the Court began its discussion of free association not with the Tocquevillian paradigm of mediating institutions but with a paradigm of intimate associations such as the family. ${ }^{222}$ The Roberts Court declared that such intimate associations received the highest constitutional protection for their autonomy because of their value to human personhood, but that economic organizations received the least. ${ }^{223}$ In effect, the Burger Court envisioned a linear gradient of protectable expression with two diametrically opposed poles represented by political or intimate associations on the one hand (high levels of protection) and economic associations on the other (little or no protection).

219. See, e.g., NAACP v. Claiborne Hardware Co., 458 U.S. 886 (1982) (permitting political association to engage in a boycott that would otherwise be invalid under the antitrust laws); In re Primus, 436 U.S. 412 (1978) (voiding a Bar Association rule that inhibited a litigating organization from pursuing its ideological agenda); Abood v. Detroit Bd. of Educ., 431 U.S. 209 (1977) (protecting the right of workers not to have their union dues used for ideological causes with which they disagree). For cases protecting the right of intimate association, see, for example, Loving v. Virginia, 388 U.S. 1 (1967) (holding that the right to interracial marriage was constitutionally protected).

220. 468 U.S. 609 (1984).

221. Id. at 627 .

222. Id. at $618-20$.

223. Id. at 620 . 
Organizations that were between these poles received some selective and intermediate measure of protection. ${ }^{24}$ The Court held that the interest of Minnesota in eradicating discrimination against women outweighed any interference in the autonomy of a large, unselective organization such as the Jaycees. The Burger Court specifically rejected the claim that admission of wonien would change the organization's philosophical cast and its general positions. In rejecting this position, it found that "nnsupported generalizations" about men and women formed the foundation of this argument. ${ }^{225}$ Its opinion underscored the low value its jurisprudence placed on the value of private associations as decentralized norm-setting discovery machines. The Court casually analogized the Jaycees' decision to exclude women to cases where the Court invalidated government exclusions based on such generalizations. ${ }^{226}$ The distinction between private action and government action seemed of little import to the Court in this area.

In the 1990s, as the government increasingly sought to apply antidiscrimination laws to organizations, issues regarding the autonomy of nonpolitical associations continued to make their way to the Court. ${ }^{227}$ The Rehnquist Court has begun to address these claims in a more sympathetic manner than the Warren or Burger Courts. Beginning with Hurley $v$. Irish-American Gay, Lesbian and Bisexual Group of Boston, the Rehnquist Court invigorated the principle of expressive association in the context of nonpolitical associations. ${ }^{228}$ In that case, Massachusetts attempted to apply its public accommodation law to require the organizer of Boston's St. Patrick's Day Parade to permit a homosexual group to march under a banner proclaiming themselves Irish gays, lesbians, and bisexuals. ${ }^{229}$ The Court held that the law could not be applied to a parade because requirmg the parade organizers to imclude a group whose message "alter[ed] the expressive content of their parade" violated their First Amendment rights. ${ }^{230}$

The Court's decision in Boy Scouts of America v. Dale ${ }^{231}$ provided a more emphatic defense of the principle of expressive association and remforced Hurley, because the unwanted message at issue was not conveyed

224. Id. at 617,620 .

225. Id. at 628 .

226. Id. at 628-29. A jurisprudence of spontaneous order would not make this analogy, because private associations provide their social output in the form of social norms that can be chosen by their members, whereas the government produces regulations that must be obeyed by all citizens.

227. Very early in the Rehnquist era, the Court decided two cases against freedoin of association rights based on the Roberts precedent. See Bd. of Dirs. of Rotary Int'l v. Rotary Club of Duarte, 481 U.S. 537 (1987) (upholding the application of California human rights laws to require the Rotary Club to admit women); New York State Club Ass'n v. City of New York, 487 U.S. 1 (1988) (rejecting facial challenge to a New York City ordinance requiring clubs where business is conducted to admit women).

228. 515 U.S. 557 (1995).

229. Id. at 561 .

230. Id. at 572-73.

231. 530 U.S. $640(2000)$. 
by a banner but by the identity of the one of the members. ${ }^{232}$ James Dale was an assistant scoutmaster of the Boy Scouts. ${ }^{233}$ The Boy Scouts had expelled him from the organization after he acknowledged in a newspaper interview that he was co-president of the Rutgers University Lesbian Gay Alliance. ${ }^{234} \mathrm{He}$ sued for reinstatement under a New Jersey law prohibiting a "place of public accommodation" from discriminating on the basis of "sexual orientation." 235 Boy Scouts of America ("BSA") claimed that application of the New Jersey public accommodation law would violate its rights of the expressive association under the First Amendment. ${ }^{236}$

Again writing for the majority, Chief Justice Rehnquist held that applying New Jersey's public accommodation law to require BSA to admit Dale violated BSA's First Amendment right of expressive association. He began by saying that "implicit in the right to engage in activity protected by the First Amendment" is " a corresponding right to associate with others in pursuit of a wide variety of political, social, economic, educational, religious, and cultural ends." 237 While freedom of association is not absolute, the state must have a compelling interest, "unrelated to the suppression of ideas," to override that freedom. ${ }^{238}$

First, Chief Justice Rehnquist held BSA's interest in excluding Dale was based on an expressive judgment about homosexuality. He found this viewpoint expressed in BSA's interpretation of what it meant to be "morally straight," a central concept in the Scout Oath and Law. ${ }^{239}$ To the New Jersey Supreme Court's contention that open homosexuality was not inconsistent with being a morally straight scoutmaster, the Chief Justice responded that deference was due to BSA's own interpretation. ${ }^{240}$ The Court further held it immaterial that BSA's purpose was not to dissemmate views about homosexuality. So long as the association engaged in expressive activity that could be impaired by forced inclusion, it was entitled to First Amendment protection. ${ }^{241}$ The Court concluded that admitting Dale

232. Id. at 647 .

233. Id. at 644 .

234. Id. at 645 .

235. N.J. StAT. ANN. $\$ \S 10: 5-4 \&$ 10:5-5 (West 1993). The Supreme Court of New Jersey ruled that the Boy Scouts of America were a public accommodation. Dale v. Boy Scouts of America, 734 A.2d 1196 (N.J. 1999).

236. Dale, 530 U.S. at $646-47$.

237. Id. at 647 (quoting Roberts, 468 U.S. at 622).

238. Id. at 648 .

239. Id. at 649-50.

240. The Court noted that BSA had expressed this interpretation before the litigation. Id. at 65152.

241. The Court also held that it was irrelevant that some members of BSA disagreed with the policy on homosexuals, stating that toleration of "dissent in its ranks, does not mean that its views receive no First Amendment protection." Id. at 656. 
would be a significant burden on BSA's advancement of its concept of being "morally straight."242

Dale can be understood as protecting the autonomy of civil society from the state, because it marks only the second time in the last fifty years where the Court set aside a state antidiscrimination law on grounds of freedom of association (the first being Hurley). Moreover, its holding was much bolder than that of Hurley, because the expressive interest it protected was far subtler than the interest in Hurley. ${ }^{243}$ By granting such substantial space for a private organization to exclude individuals whose mere presence is antithetical to their expressive norms, the Court turned the First Amendment into a powerful tool for private articulation of social norms about individual behavior and characteristics.

Moreover, these characteristics do not have to be ones that everyone agrees would undermine the organizations' expressive purpose. It is the organization's understanding of the relationship between its organizational structure, including its membership, and its expressive purpose that matters. By allowing the organization substantial discretion in the manner of establishing these social norms, ${ }^{244}$ the Court allows private associations to exert subtle social pressures through relatively quiet judgnients. Finally, in protecting exclusions that might not be deemed central to the organization's purpose, the Court allows private organizations with very general purposes, such as raising "sound" young men according to its own view of soundness, to exert a general influence that may interact with the day's more narrowly gauged social movements.

Thus, Dale exemplifies the Court's revival of a constitutional space for civil associations of the kind Tocqueville celebrated as central and constitutive of American democracy. ${ }^{245}$ The Court previously has been vigilant in protecting the rights of political associations selecting their meinbers for political purposes. ${ }^{246}$ It is important to remeinber that Tocqueville divided

242. Id. at 652-62. It distinguished the case in which the Court had refused to permit the Jaycees to exclude women on the grounds that the association there had not demonstrated any serious burden on their message. Id. at 659 .

243. The expressive interest in Hurley was an association's interest in controlling the message it conveys. The expressive interest im Dale was one step removed from this: the interest in controlling the association's membership so as to make the formation and delivery of the association's message more effective.

244. According to the Cour, "it does not have to trumpet its views from the housetops." Id. at 656.

245. See supra note 215.

246. For example, all sides in Dale agreed that no one could have ordered an organization that opposed homosexuality to admit homosexuals. See, e.g., Brief Amicus Curiae of the American Civil Liberties Union in Support of Respondent at 30, Boy Scouts of America v. Dale, 530 U.S. 640 (2000) (No. 99-699) (conceding that a group dedicated to antisemitism could not be forced to admit Jews). This proposition follows froin Roberts, where the Court implied that an organization that was selective (presumably including selectivity on the basis of political views) had a First Amendment right to exclude those whoin they would not select. 
associations into two kinds: political and civil. ${ }^{247}$ But Tocqueville actually believed that civil associations provided a greater benefit to a democratic society than political ones because they created civic energy without gcnerating the factional strife of political associations. ${ }^{248} \mathrm{He}$ warned that government should not be permitted to supervise or manage civil associations lest their independent influence on society be diluted. ${ }^{249}$ The Dale Court followed Tocqueville's admonition in prohibiting regulation of expressive association. Otherwise, the role of mediating institutions in constructing civil society and setting social norms would have been compromised.

Seen in this light, the objections to constitutionally protecting BSA's policy are really objections to a larger role for civil associations vis-à-vis the government in creating social norms. For instance, in his dissent, Justice Stevens expressed his belief that Dale should not be excluded because BSA's views on homosexuality were not at the core of the organization; BSA was not a relentless public advocate against homosexuality. ${ }^{250}$ But the advantage of having a full range of civil associations lies in society's enjoyment of a range and intensity of views on an issue pressed from different perspectives. An alternative constitutional world, which provides special solicitude only for the autonomy of groups with an express political agenda and neglects that of civil associations, is one whcre contentious political advocacy alone supplements the norms encouraged by the government. $^{251}$

Justice Stevens also complained that BSA's formally expressed objections to homosexual scoutmasters seemed of recent origin, perhaps formulated only after Dale's expulsion. ${ }^{252}$ However, even if that were true, one of the advantages of mediating institutions is that they adapt their concepts to apply to new situations. The ability of private associations quickly to translate their principles to new contexts is one of the benefits of spontaneous order in addition to its relative imperviousness to special interest and symbolic politics. A civil association is not an administrative agency, ${ }^{253}$ and is

247. See 2 Democracy In AMERICA, supra note 21, at 115 .

248. See id. at 117-18 (valuing political associations chiefly because they give citizens the habit of joining associations and thus facilitate civil associations).

249. Id. at 312 (discussing the government tendency to prcvent associations froin departing from rules laid down by government).

250. Dale, 530 U.S. at 687 (Stevens, J., dissenting).

251. It may be argued that giving scope for discrimination over any characteristics threatens a liberal polity that should judge only by behavior. But in an age of identity politics, where many citizens choosc their identity in some measure, it is hard to argue that identity itself is not an inportant aspect of social ordering. Thus, if one agrees that private ordering is better at discovering social norms than centralized democracy, identity should be subject to the judgments of private associations. As discussed below, prior judicial precedent and the intent of the Fourtecnth Amendment limit this principle from precluding legislation against racial discrimination.

252. Dale, 530 U.S. at 673-74 (Stevens, J., dissenting).

253. Indeed a civil association is like a religious association; the Court has a long tradition of deferring to the religion's own view of its practices rather than substituting its own judgment. The 
not subject to the same requirements that its rules be clear or issued only after notice and comment. ${ }^{254}$

BSA's power comes principally through the persuasiveness of its reasoning, and above all, its success in the enterprise of raising boys. Like any organization created through spontaneous ordering, BSA's policy decisions are subject to a self-correcting inechanism because they put the organization at risk of losing members and civic respect. Indeed, this mcchanism of social control over expressive associations is an important aspect of understanding Dale, because the public can bring pressure to bear on private associations to alter their expressive positions. The real world aftermath of the Dale decision suggests that if one private association's norms are not persuasive, other organizations that engage in activities similar to scouting but that admit homosexuals will gam in popularity. ${ }^{255}$ Moreover, homosexual rights groups can also bring pressure to bear on BSA for their admission through other associations on whom BSA depends for resources and approval. In fact, with some success, such groups began asking organizations supporting BSA to withdraw their support immediately following the Court's decision. 256

Thus, it appears that mainstream civil associations in the modern era are connected to a web of other organizations. Accordingly, over time, the private discovery machine for values will take a wider spectrum of belief and concerns into account. Another advantage of permitting these networks, rather than government, to shape the policies of civil associations is that if an association, like BSA, changes it policies, it will do so voluntarily. The voluntariness of its act will help prevent a backlash against its ultimate decision, while preserving the autonomy of such beneficial private associations.

Justice Stevens suggested that this case represents an amimus on the Court toward homosexuals. ${ }^{257}$ A comparison with another Rehnquist Court

Court has in fact permitted churches to have complete autonomy with respect to their appointments and organizations. See Douglas Laycock, Towards a General Theory of Religion Clauses and the Right to Church Autonomy, 81 Colum. L. REv. 1373, 1395 (1981); Steffan N. Johnson, Expressive Autonomy and Organization Autonomy, 85 MrN. L. REv. 1639, 1652 (2001) (making this point in connection with civil associations). I argue below that the Constitution mandates equivalent treatment for religious and secular expression and for religious and secular associations, see infra Parts IV.B-C and accompanying text, and therefore count this analogy strongly in BSA's favor.

254. See, e.g., David A. Westbrook, Liberal Environmental Jurisprudence, 27 U.C. DAVIS L. REV. 619,661 (1994) (understanding administrative law as a tragic necessity required by the need for government coercion to address externalities).

255. See, e.g., David Crary, Furor Persists over Boy Scouts' Gay Policy, Deserer News, June 24, 2001, at D7 (noting that more boys are joining Camp Fire Boys and Girls, whose policy against nondiscrimination includes sexual orientation).

256. See Heather MacDonald, Boy Scout Battle Pits Gay Activists vs. Minority Kids, WaLl ST. J., July 6, 2000, at A26.

257. Dale, 530 U.S. at 699-700 (Stevens, J., dissenting). 
decision, Romer v. Evans, ${ }^{258}$ shows that this claim is too facile. In that case the Court struck down an amendment to Colorado's constitution adopted by referendum that precluded Colorado and any of its political subentities from prohibiting discrimination on the basis of homosexual conduct or orientation. The Romer Court held that the Fourteenth Amendment prevented Colorado from forbidding only homosexuals from seeking privileges that other groups "enjoy or may seek."259 Thus, through the Fourteenth Amendment, the Court rejected the attempt of citizens to use the democratic process to single out homosexuals for what it regarded as special disabilities in the political process. A jurisprudence that embraces a philosophy of spontaneous order can explain the decisions in both Dale and Romer. Dale maximized the autonomy of private mediating institutions to set their own norms, while Romer required the government not to discriminate in the norms it applied.

Notwithstanding this coherence, as with federalism, it remains an open question how far this revolution in protecting the expressive autonomy of associations will progress. First, it is not entirely clear how the Court will reconcile the analysis in Dale with Roberts. The opinion in Roberts upheld the application of an antidiscrimination statute to a civil association largely by reference to the compelling interest the state has in preventing discrimination against women. ${ }^{260}$ Dale, in contrast, tested the constitutionality of the statute by inquiring not into the state's interest in preventing discrimination against homosexuals, but into the burden on BSA's expressive rights, which it found outweighed the burden of the antidiscrimination law on the Jaycees in Roberts. ${ }^{261}$ it gave no indication of how the balance between expressive associative rights and a state statute would be different if the statute were supported by a compelling interest.

Second, viewed less doctrinally and more sociologically, Dale leaves open the question of whether the Court might be less willing to permit associations to exclude other identifiable groups on First Amendment grounds. One reason for the Warren and Burger Courts' greater willingness to allow states to infringe on civil associational rights was the need to combat racial discrimination, partly because the state was responsible for its institution. ${ }^{262}$ The nation's original sin of slavery, for a time, weakened the strength of the United States' greatest political virtue: the principle of free association. However, as the concern of state-sanctioned discrimination against African Americans has faded in intensity, the principle of free

258. 517 U.S. $620(1996)$.

259. Id. at 631 .

260. Roberts, 468 U.S. at 624-27.

261. Dale, 530 U.S. at 655.

262. For discussion of this point, see supra note 66 and accompanying text. 
association is once again asserting itself. ${ }^{263}$ Nevertheless, one might still expect the Court to give more discretion to the government in preventing discrimination against racial minorities, particularly African Americans. ${ }^{264}$ It might justify this distinction doctrinally because minorities are the paradigmatic protected class under the Equal Protection Clause of the Fourteenth Amendment. Therefore, preventing their exclusion from associations justifies heavier burdens on nonprofit organizations. ${ }^{265}$

Third, although Tocqueville included both profit and nonprofit groups under the rubric of civil association, the Court, in the near term, will surely allow the state to apply antidiscrimination law against associations with an economic purpose. ${ }^{266}$ The Court has never suggested that it would invalidate laws related to economic matters on freedom of association grounds. ${ }^{267}$ The line drawn in freedom of association parallels the line drawn in the federalism area: the Court is more willing to allow decentralization in noneconomic than in economic inatters. Thus, in both the

263. Some commentators have suggested that those who use rhetoric based on the freedom of association to raise questions about the application of antidiscrimination laws "sound like voices from another world." See Post \& Siegel, supra note 168, at 493. But they are wrong as a descriptive matter, since a majority of the Supreme Court in Dale used the principle of freedom of association to strike down a state law. They are also too quick to suggest that the laudable legislation of the civil rights movement should permanently quash the principle of free association-a principle that Tocqueville saw as constitutive of America. African Americans suffered to an extent no other group did from racist laws, and given that history it was prudent to modify the principle of association to address the injustices that they uniquely suffered. But to suggest that this adjustment in this extraordmary case should erase the constitutional principle of free association from American jurisprudence is an overinterpretation of the civil rights movement.

264. This approach is one way to distinguish Runyon v. McCrary, 427 U.S. 160 (1976), in which the Supreme Court did not accept a freedom of association defense to an antidiscrimination claim against a private school. Another way to distinguish Runyon is that the school did not argue that their expression of segregationist values would be harmed by the admission of African Americans. The Runyon Court expressly noted that "there is no showing that discontinuance of ... discriminatory admission practices would inhibit in any way the teaching in these schools of any ideas or dogma." Id. at 176. For further discussion of this distinction, see David Bernstein, Boy Scouts of America v. Dale: The Right of Expressive Association and Private Universities' Racial Preferences and Speech Codes, 9 WM. \& MARY BILl RTs. J. 619, 626-27 (2001).

265. See, e.g., Bob Jones Univ. v. United States, 461 U.S. 574, $603-04$ (1983) (holding that a compelling interest im eliminating racial discrimination in education could justify limited infringement on rights of religious association by denying tax exemption to a racially discriminatory religious school). This argument could raise counterarguments. The Fourteenth Amendment is directed against state action, see Morrison, 529 U.S. at 621, and thus it is unclear why the special constitutional solicitude for African Americans when it comes to preventing state discrimination should spill over to justify statutes attempting to eliminate private discrimination.

266. For a full defense of the distinction between commercial and noncommercial enterprises in the doctrine of expressive association, see Dale Carpenter, Expressive Association and AntiDiscrimination Law After Dale: A Tripartite Approach, 85 MINN. L. REv. 1515, 1582 (2001) (arguing that noncommercial associations need more protection than commercial associations, because commercial associations have more access to capital and because identity is generally more important in noncommercial associations).

267. Justice O'Connor has already suggested this by saying that associations organized for economic purposes have no rights of association under the First Amendment. See Roberts, 468 U.S. at 634 (O'Connor, J., concurring). 
federalism and expressive association area, the Court is adapting Tocquevillian principles to take account of the social democratic view that the government has a more compelling interest in regulating the economic sphere because that sphere is potentially the greater source of exploitation and inequality. ${ }^{268}$

\section{B. The Congruence of Political and Civil Associational Rights}

Just two days before Dale, the Supreme Court decided another case regarding freedom of association that strengthens the argument for Dale's correctness. ${ }^{269}$ In California Democratic Party $v$. Jones, ${ }^{270}$ a seven-member majority invalidated California's blanket primary rule. ${ }^{271}$ That rule made all registered voters eligible to vote in a single primary that had all the candidates seeking nomination from every party on a single ballot. ${ }^{272}$ The candidate from the each party with the highcst vote was then selected as the party's nominee for the general election. ${ }^{273}$

Justice Scalia, writing for the Court, declared this election regulation unconstitutional. Justice Scalia began by noting that prior cases had held that the Constitution limited the ability of the government to structure a party's selection process. ${ }^{274} \mathrm{He}$ then observed "a corollary of the right to associate is the right not to associate."275 Thus, if a party preferred to

268. Nevertheless, in the long run, this distinction may be as unstable as the distinction between the nonprofit and profit-making spheres. As society becomes wealthier, the distinction between what many people do for a living and what they do to express themselves blurs. Second, as our economy becomes an information economy, much of the actual content of business has an expressive content and the image of the business-who it employs and how it is structured-becomes hard to separate from the content it delivers. See McGinnis, supra note 206, at 54-55 (suggesting that in the new economy "[e]xpressive man is economic man").

269. Daniel Farber nicely notes the proximity of these cases. See Daniel Farber, Speaking in the First Person Plural: Expressive Associations and the First Amendment, 85 MinN. L. REv. 1483, 1501 (2001). I have, however, some serious disagreement with Professor Farber's views on civil associations. See infra notes 290-302 and accompanying tcxt.

270. 530 U.S. $567(2000)$.

271. Id. at 586 .

272. Id. at 57I.

273. Id.

274. Id. at 572-73. The Court mentioned some areas in which it had upheld the right of the state to regulate political associations. These can be divided into two areas. The first area includes cases where regulation is necessary to promote a compelling state interest in creating smooth machinery of election, such as requiring parties to show some substantial support to prevent the ballot from being burdened by frivolous candidacies. See, e.g., Jenness v. Fortson, 403 U.S. 431 (1971). I would put the requirement to conduct a primary election in the same category, since winning a primary election is a way of assuring that a candidate has some substantial support for the general election. See American Party of Tex. v. White, 415 U.S. 767 (1974). The other area is a series of cases that limited participation in primaries to Whites. See, e.g., Smith v. Allwright, 321 U.S. 649 (1944). Like other limitations of freedom of association in the context of discrimination against African Americans, I see the latter cases as attempting to extirpate the vestiges of state-sponsored discrimination, and thus they should have limited generative power outside that context. See supra notes 262-65 and accompanying text.

275. Jones, 530 U.S. at 574. 
permit only its members to have a say in the selection of their party's designated champion, the party had a right to exclude all others.

The state argued that a blanket primary "compels... [parties to choose] candidates to appeal to a larger segment of the electorate."276 Justice Scalia sharply rejected that arguinent, suggesting that such an interest "reduce[d] to nothing more than a stark repudiation of freedom of political association: Parties should not be free to select your own nominees because these nominees, and the positions taken by those nominees, will not be congenial to the majority."277 $\mathrm{He}$ then analogized the right of political association to the right of the civil association, observing "we have recognized the inadmissibility of this sort of 'interest' before" and citing Hurley for that proposition. ${ }^{278}$

This analogy supports the result in Dale. If political parties can exclude individuals whose identity or behavior will undercut the process by which they reach their decisions about candidates, why cannot civil associations similarly exclude individuals whose identity, views, or behavior will undercut the process by which they formulate their norms? ${ }^{279}$ The

276. Id. at 582 .

277. Id.

278. Id. (citing Hurley v. Irish-American Gay, Lesbian and Bisexual Group of Boston, Inc., 515 U.S. 557, 557 (1995)).

279. The congruence between the decisions in Dale and Jones also raises serious doubts about Professor Jed Rubenfeld's recent attack on the Dale decision. (See Jed Rubenfeld, The First Amendment's Purpose, 53 STAN. L. REV. 767 (2001)). Professor Rubenfeld argues that the decision is wrong because the First Amendment provides no exemption from generally applicable laws regulating conduct so long as those rules do not have the pupose of suppressing expression. Professor Rubenfeld asserts that the purpose of Dale antidiscrimination law was to regulate conduct, that is, membership in an association, not delivery of the association's messages, and thus should face no scrutiny under the First Amendment. Id. at 808. But if Dale is wrong on these grounds, then so is Jones because it also regulates what Professor Rubenfeld calls conduct, that is, participation in a primary and the formation of the party's message, rather than the delivery of messages. We do not know how Professor Rubenfeld would distinguish Jones from Dale because he does not discuss Jones. But under his theory, the distinction between Jones and Dale cannot be that a blanket primary has a serious effect on the messages that parties can deliver because Professor Rubenfeld concedes that the antidiscrimination law at issue in Dale might have a serious effect. Indeed, the central point of his article is sharply to separate purpose from effect as a test of First Amendment legality.

Professor Rubenfeld's analysis is flawed because associations cannot be assimilated to conduct for two interrelated reasons. Association is more essential to producing norms than any actual conduct. There are always alternatives, though some are perhaps lesser alteruatives, to some kind of conduct for expressing one message. But to saddle an association with people who undermine their message potentially destroys the formation of group expression rather than burden a particular means of expression. Cf. Carpenter, supra note 266, at 1558-59 (discussing importance over control of the membership of organizations concemed with homosexuality for delivery of their message). For that very reason laws regulating association, even if generally applicable, are more likely to be an attempt by the majority to eliminate unpopular norms than the average regulation of conduct. At some level, California primary law was an attempt to create more moderate candidates, thereby avoiding the injection of "extreme values" into the political process. Analogously, the law at issue in Dale was trying to stamp out the expression of social norms that homosexuality is wrong. In short, association is nearer to speech and belief than conduct. Its importance to message formation and its consequent 
alternative is, to paraphrase the Court in Jones, a stark repudiation of freedom of civil association: associations would not be able to select their own members because the expressive norms those selections represent will not be congenial to the majority. ${ }^{280}$

Certainly the difference between a political expressive association and a civic expressive association cannot be that a civil association is less important to society's health than political associations. Tocqueville himself thought that civil associations were more valuable than political associations. ${ }^{281}$ That judgment is even truer now than it was then because, as the government has grown, political parties have even greater incentives to use the resources that the leaders of government can gain through taxation to provide spoils to the factions that are the mainstays of their political support. Such political activity divides rather than unites society, because citizens begin to regard one another as threats to their well-being. In contrast, civil associations are generally not organized around the possibility of government coercion and thus pose less risk of social division.

\section{Permitting Government Aid to Civil Associations on a Neutral Basis}

Just as the Court has moved to prohibit the government from interfering with formation of civil associations' messages, it has also protected the government's ability to provide (on a neutral basis) resources to facilitate the formation of those messages. Thus, in Board of Regents of the University of Wisconsin System v. Southworth, ${ }^{282}$ the Court allowed a state university to create a funding infrastructure for facilitating civil associations so long as the university had procedures to assure the allocation of funding was viewpoint neutral. ${ }^{283}$ In Southworth, a group of students sued the University of Wisconsin to prevent their activity fees from being used to support student groups, because the students disagreed with some of the groups' agendas. ${ }^{284}$ They argued that being forced to support groups they opposed violated their First Amendment rights.

The Court unanimously disagreed. Justice Kennedy, writing for the majority, held that the university had an interest in facilitating free and open exchange of ideas among its students. ${ }^{285}$ The Court conceded that the

vulnerability to majoritarian interference mean that it deserves a stronger regime of constitutional protection.

280. Jones, 530 U.S. at 582.

281. See supra note 248 and accompanying text. It is true that, by the time of writing his second volume, Tocqueville also saw some value in political associations as well. See 2 DEMOCRACY IN AMERICA, supra note 21, at 115-16.

282. 529 U.S. $217(2000)$.

283. II. at 233.

284. Id. at 221.

285. Id. at 234. Justice Souter, in an opinion joined by Justices Stevens and Breyer, did not join the majority opinion because he disagreed with a "cast-iron viewpoint neutrality protection." Id. at 236 (Souter, J., concurring). 
subsidy program implicated the students' First Amendment rights because they are forced to subsidize speech they find offensive. ${ }^{286}$ It held that, in the university context, assuring that the university funded organizations on a viewpoint neutral basis would vindicate their rights. ${ }^{287}$ Most of the university's programs met that criterion, but a majority of the Court held that a referendum process on campus, which was also a possible vehicle for funding organizations, substitutes the majority's assessment of an organization's worthiness for viewpoint neutrality and so was suspect under the First Amendment. ${ }^{288}$

Southworth is also consistent with a jurisprudence that promotes civil associations and competition im social norms. Given free-rider problems, it is often difficult to form private associations. Public funding thus may act as a useful catalyst for generating civil associations. So long as the government does not favor one association over another, it does not disturb, rather it intensifies, the competition in social norms. ${ }^{289}$ While the Southworth holding was limited to the university setting, its reasoming would support similar government structures for buildimg a viewpoint infrastructure to support civil associations.

Recently, Professor Daniel Farber, however, has raised some doubts about whether the government should encourage civil associations because he (and, he argues, the Framers as well) believes such associations create some serious risks for the polity. He quotes Robert Putnam:

Many of America's Founding Fathers, however, didn't think much of voluntary associations. They were famously opposed to political parties and local political committees, as well as to any other group whose members might combine to threaten political stability. Indeed, James Madison himself called groups organized around particular interests or positions 'mischiefs of faction,' whose presence must be tolerated in the name of liberty, but whose effects on the polity inust be controlled. Madison's fear, which reverberates among today's critics of Washington lobbyists and special interest groups, was that elected representatives, swayed by these 'factions,' would sacrifice the good of the whole for the pet projects of the few. ${ }^{290}$

According to Farber, such factions will have a disproportionate influence over the government, as public choice theory suggests. ${ }^{291}$

286. Id. at 229.

287. Id. at 234.

288. Id. at 235.

289. Cf. Gameth, supra note 210 , at 1859 (noting congruence between a viewpoint-neutral mechanism upheld in Rosenberger and that upheld in Southworth).

290. See Farber, supra note 269 , at 1507 (quoting PutNAM, supra note 23, at 337).

291. Id. 
But the Framers nevertheless tolerated all factions ${ }^{292}$ and were right to do so because all interest groups, including civic associations, generate information without which democracy cannot work. ${ }^{293}$ Moreover, the kinds of factions on which public choice theorists focus are those that are able to organize even without government aid and that are aimed at vindicating narrow economic interests. ${ }^{294}$ In contrast, the kinds of associations that benefit from the kind of aid at issue in Southworth are not such factions, but associations with broader philosophical goals. These latter kinds of groups may in fact be important counterweights to narrower economic interests. Civil associations are also more valuable because they generate social norms necessary to supplement those norms emerging by way of democratic institutions. ${ }^{295}$

Indeed, the social norms of the kind generated by civil associations help provide the necessary framework for republican democracy. The Framers recognized that democracy was not self-generating. Rather it depends crucially, more than other forms of government, on habits and restraints that are not entirely natural to the human condition, requiring cultivation to flourish. ${ }^{296}$ They did not believe that statesmen can supply these virtues from above ${ }^{297}$ Civil associations offer the prospect of supplying them from below, thus providing for each generation the suitable set of religious and moral norms that George Washington himself saw as the "indispensable supports" for republican government. ${ }^{298}$

Thus, the Framers did not attempt to obstruct political associations, let alone civic ones. Instead, they sought to structure government so that factions could not unduly influence decision making. ${ }^{299}$ We have already discussed federalism as one such structure promoting limited and effective

292. The Federalist No. 10, supra note 17, at 46 (arguing that factions cannot be removed without either destroying liberty or giving everyone the same opinions or interests). The first expedient would be "unwise" and "worse than the disease." The second would be "impracticable." Id.

293. See Dwight R. Lee, In Defense of Excessive Government, 65 S. Econ. J. 674, 680-84 (1999) (noting that associations have incentives to produce information relevant to the political process that individuals lack).

294. See supra note 80 and accompanying text for discussion of economically based interest groups.

295. For problems democracy has in generating good social norms, see supra notes $79-86$ and accompanying text.

296. See Thomas K. Lindsay, Defending Liberalism, 82 lowa L. Rev. 943, 957 (1997) (reviewing Stephen Holmes, Passions and Constraint: ON the Theory of Liberal Democracy (1995)) (arguing that Framers thought democratic institutions particularly depended on individual virtues of citizens).

297. See The Federalist No. 10, supra note 17, at 49.

298. See George Washington, Farewell Address to the Nation (1796), reprinted in A Compilation of the Messages and Papers of the Presidents, 1789-1897 (James D. Richardson ed., Government Printing Office 1896).

299. This kind of structure is consistent with the general view in classical legal theory that constitutions should channel the inclinations citizens already have for the common good, rather than transform those inclinations, because the latter course is doomed to failure. 
government. ${ }^{300}$ Bicameralism, presentment, and the separation of powers represent other structural restraints in this area. ${ }^{301}$ If these structures are declining, we should think of ways to revive them or find substitutes better adapted to our time rather than eliminate support for civil associations, ${ }^{302}$ because such structural restraints will reduce any undue leverage of civil associations on the government, while retaining their advantages $\mathrm{m}$ generating social norms. I would transform Professor Farber's warming into a valuable reminder that Tocqueville and the Framers imagined that civil associations are best combined with a government limited by such structures as federalism and the separation of powers to make a harmonious whole. ${ }^{303}$ Civil associations without limited government do not work as well as the two operating in concert.

IV

\section{Creating Constitutional SPACE For COMPetition From RELIGIOUSLY BACKED NORMS}

The changing shape of the Free Exercise Clause and Establishment Clause, and the religious aspects of the Free Speech Clause provide yet further illustrations of the Rehnquist Court's new jurisprudence of spontaneous order. First, the Court has relaxed the Establishment Clause to permit government to provide aid to religiously based schools so long as it does so on a neutral basis that is visibly neutral to the parties. But it has not eased the Establishment Clause's strictures on government practices, such as government sponsored prayer, which are not neutral.

Second, the Rehnquist Court has similarly used the Free Speech Clause to fashion a neutrality principle, requiring the government to open its facilities and, in some cases, fund religious associations when it has done the same for secular organizations. This facilitates participation of associations and competition among different social norms. The Rehnquist Court's construction of the Free Exercise Clause, which does not provide exemptions from generally applicable laws for religiously motivated conduct, provides a similar neutrality principle, putting secular and religious associations on a more similar footing. However, religious associations,

300. See supra Part II and accompanying text.

301. See John O. McGinnis \& Michael B. Rappaport, Our Supermajoritarian Constitution, 80 TEX. L. Rev. (forthcoming 2002) (discussing the way bicameralism and the veto power restrain imterest groups).

302. 1 have attempted to make suggestions for limiting government. See John O. McGinnis, Presidential Review as Constitutional Restoration, 51 DUKE L.J. 901 (arguing in favor of revised federalism and regulatory review orders to limit government); McGinnis \& Rappaport, Supermajority Rules as a Constitutional Solution, supra note 117 (suggesting spending supermajority rules as a restraint on special interest groups).

303. Farber also suggests that the promotion of civil associations risks government favoritism. See Farber, supra note 269, at 1508-09. But the requirement of neutrality in the First Amendment and the Establishment Clause restrains government favoritism. 
like secular associations, can invoke the protections of free speech, including the right of expressive association, to preserve their ability to form and deliver their messages.

It is not surprising that many of the most important cases in this area have occurred in the context of aid to private primary and secondary schools because public schools and their private alternatives comprise the crucible shaping the values of the next generation. A jurisprudence of spontaneous order would facilitate structures allowing competition among private associations that administer private and secondary school to shape these values rather than rely on a government-controlled school system alone.

\section{A. Moving to Government Neutrality as the Touchstone of Establishment Clause Jurisprudence}

The Rehnquist Court's Establishment Clause jurisprudence concerning public schools has moved in two seemingly disparate directions. This apparent disjointedness, however, can be explained as arising from a jurisprudence focused on invigorating competition in social norms. On the one hand, the Rehnquist Court has systematically relaxed the Warren and Burger Courts' substantial restrictions on aid to religious schools. In 1993, in Zobrest v. Catalina Foothills School District, the Rehnquist Court ended a long line of cases that seemed to impose a per se rule against sending government-funded instructors to religious schools. ${ }^{304}$ The Court extended this principle in Agostini v. Felton, reversing an earlier Burger Court decision that had prohibited the government from sending computer teachers to religious schools. ${ }^{305}$ Because the program's purpose was secular and did not risk excessive religious entanglement, Justice O'Connor, writing for the Court, held that it did not violate the Establishment Clause. ${ }^{306}$

On the other hand, the Rehnquist Court has reaffirmed and extended the famous Warren Court precedents prohibiting prayer in schools. ${ }^{307}$ In Lee v. Weisman, ${ }^{308}$ the Court held that a religious invocation at a public school graduation ceremony was a violation of the Establishment Clause. ${ }^{309}$ Similarly, in Stone v. Graham, ${ }^{310}$ it refused to permit the posting of the Ten

304. 509 U.S. 1 (1993) (upholding a program sending federally funded sign langnage interpreters to accompany deaf children to religious schools).

305. Agostini v. Felton, 521 U.S. 203 (1997) (overruling Aguilar v. Felton, 473 U.S. 402 (1985)).

306. Id. at 224, 231-32.

307. See Engel v. Vitale, 370 U.S. 421 (1962) (holding unconstitutional the compulsory daily prayer in New York public schools); Sch. Dist. of Abington Township v. Schempp, 374 U.S. 203 (1963) (ruling that it was an Establishment Clause violation to require daily Bible readings in public schools).

308. 505 U.S. 577,590 (1992).

309. Id.

310. 449 U.S. 39 (1980). 
Commandments at a public school. ${ }^{311}$ In fact the Rehnquist Court has never upheld a religious practice sponsored by a public school. Even outside the school context, as in County of Allegheny v. $A C L U,{ }^{312}$ the Court strengthened the Burger Court precedents, such as Lynch v. Donnelly, by restricting the government from being involved in sending a religious message. ${ }^{313}$

While these two lines of cases may appear superficially to be in tension, they are reconcilable in a jurisprudence of spontaneous order: government can build the infrastructure to facilitate coinpetition between norms, including religious norms, but cannot impose religious norms. To put it another way, the government can promote a climate where Tocqueville's mediating institutions, including religious institutions, can better flourish, but it cannot try to supplant thein by generating religious values itself.

Generous government funding for public schools has created the need for government action to provide equal opportunities for private schooling, including religious schooling. Given the high taxes assessed for public schools in particular and the welfare state in general, only government assistance will allow private and religious schools to compete on anything resembling an equal basis with government schools in forming the social norms of the next generation. As Michael McConnell has acutely observed, "as long as the domain of collective decision making is small, religious freedom is protected ... as a byproduct of a limited state. As the domain of government increases in scope, soine government involvement in religious activity becomes necessary if religious exercise is to be possible at all."'114

In the case of school funding, this general observation takes a very concrete form. The taxes that individuals, at least those of modest means, pay for public schools and other services can sharply reduce the amount they have to expend on schools of their choice. Because the federal government also provides aid for public education, the same problem recurs at the federal level. Permitting the government to provide what is the economic equivalent to a tax subsidy is necessary to allow educational norms backed by religions to compete equally with norms derived from either secular private or public schools. Otherwise the public school system

311. Id. at 42-43. In Edwards v. Aguillard, 482 U.S. 578 (1987), the Supreme Court, citing the school prayer cases, held that public schools could not teach creationism.

312. 492 U.S. 573 (1989).

313. In Allegheny, the Court held that it was impermissible for a courthouse to display a nativity scene. Id. at 598-601. Allegheny turned on an endorsement test: a religious display would violate the Establishment Clause if it represented an endorsement of religious belief. Id. at 593. Some commentators have argued that Allegheny took a more stringent approach to religious messages than the Burger Court's decisiou in Lynch v. Donnelly, 465 U.S. 668 (1984), which narrowly rejected an Establishment Clause challenge to a nativity display. See Ira C. Lupu, Government Messages and Government Money, 42 WM. \& MARY L. REv. 771, 802-04 (2001).

314. Michael W. McConnell, Why Is Religious Liberty the "First Freedom"?, 21 Cardozo L. REv. 1243, 1261 (2000). 
forces parents who want the advantages of religiously backed norms to pay twice, once for a public school they reject and once for a school that acts, in loco parentis, consistently with their own values. In the contemporary context of schooling funded by taxation, government aid is fuel that helps keep religious discovery machines running at the same rate as their secular counterparts.

Indeed, it may be more important in modern American society to assure that the government does not crowd out religiously backed norms by funding only the infrastructure for secular norms. Because the United States is far more prosperous now than in the nineteenth century, society's need for norms backed by religion to compete with more materialistic norms may well be even greater today. Tocqueville believed that religious belief was an important restraint on the natural materialism of a democratic people because it provided a focus on the transcendent. ${ }^{315}$ Religious-based norms compete with more materialist ones to temper the self-interest to which human nature is prone. This constraint on self-interest is important to self-governance because, as we have seen, the factions to which selfinterest gives rise can distort democratic decision making. ${ }^{316}$

Moreover, the modern era's other transformations may make a religious discovery machine for social norms a more important complement to, and restramt of, the national government. As noted above, imdividuals may lack the personal attachments to their states that federalism requires to create a powerful engine for competition between local and national sets of social norms. However, religious attachments remain a vital aspect of modern life in the United States and are a potentially stronger basis of popular support for discovery machines. ${ }^{317}$

A term ago, in 2000 , the Rehnquist Court decided a case exemplifying its interest in permitting religious attachments to be used as a basis for spontaneous order. It both deepened its commitment to support the infrastructure for private schools and reiterated its unwillingness to permit

315. See 2 DEMOCRACY iN AMERICA, supra note 21, at 143-47.

316. See supra notes $80-86$ and accompanying text.

317. See Andrew M. Greeley, Unsecular Man: The Persistence of Religion 1-12 (1972) (providing statistics on the religiosity of Americans). For further discussion of the strength of religion, see Marci A. Hamilton, Power, the Establishment Clause, and Vouchers, 31 CoNN. L. REv. 807, 815 (1999). In fact, it is striking to observe that in many of the religious aid cases decided by the Supreme Court, the federal government has provided support for private and religious education. The generosity toward facilitating the autonomy of private and religious schools stands in sharp contrast to the impulse of the federal government to strip the states of autonomy that we noted in the context of federalism. In this way, freedom of religion is not only the primary freedom in the sense of being the first liberty that the West protected against the demands of the state, it is also primary in the sense of being the most enduring reserve of personal attachments necessary to sustain competition with and limitations on centralized government. For further discussion of how religion came to be the first freedom, see McConnell, supra note 314, at 1245-50. See also Garnett, stpra note 210, at 1875 (arguing that religious schools can play an important "role of mediating institutions in educating persons and in hamstringing the ambition of the liberal state"). 
government to impose any kind of religious observance. Mitchell v. Helms, the school aid decision, was far ranging, not least because it suggested that the Court is likely to uphold school vouchers, perhaps the most powerful dynamo for remvigorating spontaneous order in social norms. ${ }^{318}$ Mitchell considered whether the Establishment Clause prohibited government funds from being used to provide secular instructional materials neutrally to both public and private schools, including religious schools. The material was required to be "secular, neutral and nonideological"319 and remained government property treated as a loan to the school. ${ }^{320}$

Writing for a four-person plurality, Justice Thomas upheld the program on the simple ground that the program was available to all schools, regardless of their religious affiliation or lack thereof. ${ }^{321}$ According to Justice Thomas, because the dispensation of school aid did not result in governmental nidoctrination and did not define recipients of aid by religion, ${ }^{322}$ the school aid provided on a neutral basis satisfied the requirements of Agostini v. Felton. ${ }^{323}$ First, Justice Thomas held that its neutrality assured that any religious nidoctrination caused by the prograin could not be attributed to the government and thus was not a government endorsement of religion. ${ }^{324}$ The plurality also assured that religion did not define the recipients of the aid. ${ }^{325}$ Justice Thomas specifically rejected the argument that the aid violated the Establishment Clause because it was divertible to religious use, noting that most instructional materials could be so used. ${ }^{326}$

Justice O'Connor, writing for Justice Breyer and herself, provided the decisive two votes to constitute the six-menber majority. ${ }^{327}$ Justice O'Connor was concerned with the breadth of the plurality's holding, particularly its claim that neutrality was all that mattered. ${ }^{328}$ She also contended that if the materials provided were actually diverted to religious instruction, this would create an impression of government endorsement of religion and thus violate the Establishment Clause. ${ }^{329}$ Justice O'Connor stated that per capita aid programs, like that at issue in Mitchell, raise more

318. See Mitchell v. Helms, 530 U.S. 793 (2000). For reasons why vouchers are so important to private ordering in social norms, see supra notes 314-16 and accompanying text.

319. 20 U.S.C. $\$ 7372(a)(1)$ (1994). Funds came from chapter two of the Elementary and Secondary Religious Education Act of 1965.20 U.S.C. $\$ 7301$ (1999).

320. 20 U.S.C. $\$ 7372(\mathrm{c})(1)$ (1994).

321. Mitchell, 530 U.S. at 811 (plurality opimion).

322. The Court did not consider whether the aid resulted in an excessive entanglement because neither the respondents nor the court below had questioned the district court's holding that no entanglement existed. Id. at 808.

323. 521 U.S. 203 (1997). See supra notes 305-06 and accompanying text.

324. Mitchell, 530 U.S. at 809-15.

325. Id. at 829 .

326. Id. at 835-36.

327. Id. at 836 (O'Connor, J., concurring).

328. Id. at 837 .

329. Id. at 841 . 
serious risks of Establishment Clause violations than true school choice programs where funds were given to students or parents of students rather than schools. ${ }^{330}$ Justice O'Connor noted that in school choice programs, the money flows to the religious school because of the citizen's choice, not the government's choice. ${ }^{331}$ Therefore, the aid cannot constitute a government endorsement of religion. ${ }^{332}$ Despite her general concern about per capita programs, Justice O'Connor nevertheless upheld the direct aid in this case because the program included adequate safeguards against diversion and there was no evidence that aid was actually diverted to religious uses. ${ }^{333}$

Mitchell fits into the previously mentioned trend of giving more constitutional space for private associations ${ }^{334}$ Mitchell achieves this result not by preventing the state from regulating private associations, but by interpreting the Establishment Clause to allow the state to aid religious organizations, so long as the state distributes these funds on a neutral basis and it diverts no funds to actual religious uses. Thus, the state is empowered to help create an infrastructure that enables associations organized for an educational purpose, whether religious or not, to compete on more equal footing with public institutions. Even if the state cannot use direct aid for religious purposes, the augmented infrastructure helps religious institutions compete in the arena of primary and secondary education.

While the Court in Mitchell upheld the government's ability to create an infrastructure to sustain competition from religiously backed norms, it also prevented the government from promoting particular religious norms itself. Thus, in Santa Fe Independent School District v. Doe, the Court concluded that student prayer at football games, when authorized as official high school policy, violates the Establishment Clause. ${ }^{335}$ Writing for the majority, Justice Stevens found that Lee v. Weisman, a case where the Court found the Establishment Clause prohibited a rabbi from delivering an invocation at a high school graduation, controlled the case. ${ }^{336}$ Justice Stevens rejected the argument that the prayer at the high school football game was private student speech, not government speech. Because the speech was delivered on school property, at a school sponsored event, over

330. Id. at $843-45$.

331. Id. at 842 .

332. Id.

333. Id. at 867. Justice Souter dissented. Id. (Souter, J., dissenting). Souter argued that the true test of whether aid to religious schools violates the Establishment Clause depends on many factors besides neutrality, including "the religious mission and education level of benefited schools and their pupils, the pathway by which a benefit travels from public treasury to educational effect, the form and content of the aid, its adaptability to religious ends, and its effects on school budgets." Id. at 899 . On the basis of this multifactor test, Justice Souter held the program a violation of the Establishment Clause. He particularly emphasized that materials could be diverted to religious use and contended that the statute lacked sufficient monitoring safeguards to prevent this diversion. Id. at 903-09.

334. See supra Part l11.

335. 530 U.S. $290(2000)$.

336. Id. at 301-02 (citing Lee v. Weisman, 505 U.S. 577 (1992)). 
the school public address system, by a speaker representing the student body, whose election the school faculty supervised, and pursuant to a school policy explicitly encouraging public prayer, he held that it should be characterized as government speech. ${ }^{337}$ The Court also emphasized that the challenged practice had replaced a chaplain's pregame prayer that had itself been challenged as unconstitutional, suggesting that the elaborate policy of electing a student speaker for a pregaine speech was a subterfuge to evade the prohibition on school-sponsored invocations by clergy..$^{338}$

While Santa $\mathrm{Fe}$ strikes down a practice under the Establishment Clause rather than upholding it, its reasoning is not in tension with Mitchell, at least if one accepts the majority's characterization of the facts. Here, the state was not giving space for religious norms to compete, but imposing a single norm through the election of a student with a process that (in the Court's view) was designed to find a student who would use the time to deliver an invocation. Santa Fe thus also supports a jurisprudence of spontancous order by discouraging norms structured through governmental processes. Therefore, government can facilitate competition between norms by providing resources that are neutral among them, but it cannot itself enter the arena on the side of one set of religious norms or another.

Because of both the strength of religious attachments and the clarity of the neutrality primciple in Establishment Clause jurisprudence, the prospects for strengthening religion as a discovery machine seein strong. The most important issue destmed for the Court in this area is the constitutionality of school vouchers. ${ }^{339}$ Upholding a voucher system would reinforce a spontaneous order in social norms more than any Court decision in the last fifty years. Upholding such a voucher system would empower individuals, particularly imdividuals of modest means, to choose to associate with institutions that they think will provide sound values and sound education for their children. ${ }^{340}$

337. Id. at 307-08.

338. Id. at 315. Chief Justice Rehnquist dissented. Id. at 318 (Rehnquist, J., dissenting). Rehnquist's principal argument was that the practice of electing a student to speak before a football game should not be challenged on its face because it might be applied in a constitutional manner. Id. He argued that if students were chosen as speakers on wholly nonsectarian grounds, such as speaking ability or popularity, they should be characterized as private speakers, free to make religious or nonreligious remarks as they chose. Id. at 321.

339. The Court has recently granted certiorari in three cases from Ohio that raise the question of the use of school vouchers for religious schools. Zelman v. Simmons-Harris, cert. granted, 69 U.S.L.W. 3756 (U.S. Sept. 25, 2001) (No. 00-1751); Hanna Perkins School v. Simmon-Harris, cert. granted, 69 U.S.L.W. 3763 (U.S. Sept. 25, 2001) (No. 00-1777); and Taylor v. Simmons-Harris, cert. granted, 69 U.S.L.W. 3764 (U.S. Sept. 25, 2001) (No. 00-1779).

340. As existing private schools demonstrate, such diverse institutions would tend to inculcate some common values, like good citizenship and concern for the community, because these are likely to make students more useful and broadly effective in a pluralistic society. Accordingly, a potential concern about discovery machines (that they will lead to social conflict by nurturing values that cannot 
On the basis of Mitchell, prospects for upholding vouchers available for use at religious schools seem promising. The plurality opinion's emphasis on neutrality suggests that there are four solid votes to uphold any voucher program that permits parents to choose the private school of their choice, regardless of its religious affiliation. While Justice O'Connor's concurrence is careful not to endorse neutrality as a controlling principle for all school aid cases, her reasoning suggests that a neutrality principle may well be the touchstone for her Establishment Clause jurisprudence on the voucher issue. ${ }^{311}$ For Justice O'Connor, the Establishment Clause mandates not only that religious norms arise from an ordering that is a result of private choices rather than government management, but that the private ordering be clearly visible. A system of vouchers makes the private ordering perfectly transparent.

Moreover, Justice O'Connor favorably cited Witters $v$. Washington Department of Services for the Blind, ${ }^{342}$ a case that upheld a government vocational voucher program allowing students to use the vouchers at a seminary. ${ }^{343}$ One possible distinction between a school voucher program and the program at issue in Witters is the amount of the aid likely to flow to educational institutions affiliated with religion. ${ }^{344}$ However, in recent years a majority of the Court has refused to consider the amount of assistance in this Establishment Clause calculus. ${ }^{345}$ Its refusal makes sense because calculating the amount of assistance offers no clear, neutral principle for judges to follow. Indeed, Justice Souter, who decried consideration of the substantiality of interstate commerce effects in Commerce Clause jurisprudence in Morrison, appears inconsistent in Mitchell arguing that the

be reconciled in the public sphere) seems unlikely to be apposite here. The overwhclming strength of the common culture fueled by such national phenomena as the mass media make it likely that the vast majority of private schools will be sensitive to turning out students who can navigate through the paths of that culture.

341. Her reservations regarding the form of aid in Helms are that direct aid to schools may create the appearance of government endorsement of religion, particularly if there appears a danger that the aid can be diverted to religious uses. Mitchell, 530 U.S. at 843 . She contrasts such direct aid with indirect aid, like funds provided by vouchers, which enable parents or students to make the choice of what school to support. Id. In the case of indirect aid, Justice O'Connor declared, "when government aid supports a school's religious mission only because of independent decisions made by numerous individuals to guide their sccular aid to that school, 'no reasonable observer is likely to draw from the facts ... an inference that the State itself is endorsing a religious practice or belief." Id. (quoting Witters v. Wash. Dep't of Servs. for the Blind, 474 U.S. 481, 493 (1986)).

342. 474 U.S. 481 (1986).

343. Id. at 489-90.

344. See Michael W. McConnell, Governments, Families, and Power: A Defense of Educational Choice, 31 ConN. L. Rev. 847, 853-54 (1999) (showing that all other rationales for upholding the voucher program at issue in Witters are also applicable to school vouchers).

345. Agostini v. Felton, 521 U.S. 203, 229 (1997) (refusing "to conclude that the constitutionality of an aid program depends on the number of sectarian school students who happen to receive the otherwise neutral aid"). Justice O'Connor was in the majority in Agostini. Moreover, in Witters, Justice $O^{\prime}$ Connor herself did not appear to rely on the fact that only a sinall portion of the educational aid would go to religious institutions. See Witters, 474 U.S. at 493 (O'Connor, J., concurring). 
substantiality of the aid can make the difference between legal assistance and a violation of the Establishment Clause. ${ }^{346}$

Since the spontaneous order jurisprudence of the religion clauses permits the government to provide substantial aid to education by religious associations on a neutral basis, it will strengthen the religious clauses' prohibitory aspect, which forbids the government from encouraging or being seen to encourage any religious norms in the educational context, as a practical and theoretical matter. First, as a doctrinal matter, the neutrality principle endorsed by the plurality in Mitchell does not eomport with permitting religious practices at events in public schools. In contrast to the patent neutrality of making vouchers available to fund the education of a person's choice, it is difficult to see how the selection of a particular religious practice at an event can be neutral or can be made to appear to be neutral. ${ }^{347}$

Second, as a practical matter, the opportunity to obtain government aid for private schools should redirect individuals wanting a greater presence of religiously based norins in their children's education away from seeking to infuse religious practices in public schools. Instead, they will focus on seeking public support for an infrastructure for all private schools, including their own religiously backed schools. In this way, the Rehnquist Court's dynamic new Establishment Clause jurisprudence should move the nation both practically and theoretically toward eliminating governmentdirected religious practices in schools.

\section{B. Protecting Religious Expression of Associations through the Free Speech Clause}

Paralleling the Court's treatment of funding for religious schools under the Establishment Clause is its treatment of access to school facilities for religious groups under the Free Speech Clause. In a series of cases, the Court has held that the First Amendinent requires that schools opening their facilities to secular groups also open them to religious groups, rejecting the argument that religious expression conducted under a neutralaccess principle presents an Establishment Clause violation. ${ }^{348}$ The most recent of these cases, Good News Club v. Milford Central School, ${ }^{349}$ is the most instructive because the contemplated after-school activity in that case

346. For a discussion of Souter's positions in Morrison and Mitchell, see supra notes 139, 333.

347. Perhaps a kind of neutrality could be guaranteed by a random selection of the religious practice for school events, but even here there would be disputes about the baseline proportions of the practices to be included in the pool to be randomly selected.

348. The leading case in this area is Lamb's Chapel v. Center Moriches Union Free Sch. Dist., 508 U.S. 384 (1993), where the Court unanimously ruled that a school violated the First Amendment when it excluded a group that wanted to show films that discussed family values from a religious perspective.

349. 121 S. Ct. 2093 (2001). 
was pervasively religious. ${ }^{350}$ The Good News Club wanted to meet after hours and engage children in reciting verses from the Bible. ${ }^{351}$ The club's leader would read Bible stories and explained how they were relevant to the children's lives. ${ }^{352}$ The school board rejected their application in part on the ground that it would violate the Establishment Clause.

Despite the sectarian nature of the religious activity, the Court condemned the attempt to exclude the Good News Club. The Court began by noting that the school had established a limited public forum by allowing clubs to use its premises after hours. ${ }^{353}$ Given the public forum, the Court held that the school could not refuse to allow the Good News Club to use the school facilities on an equal basis with the others. To exclude them because of the religious content of their after-school activities constituted viewpoint discrimination. ${ }^{354}$ Even "quintessentially religious" discussion can also be characterized properly as education in character and therefore the school must accommodate them just as all other after school activities that attempt to build character. ${ }^{355}$

Thus, the Court flatly rejected the argument that permitting the Good News Club would be an Establishment Clause violation. Citing Mitchell, the Court noted that the rule neutrally allows both religiously oriented and secular clubs to use the premises after school and observed that its neutrality was an important factor militating against a finding of an Establishment Clause violation. ${ }^{356}$ It also did not concede that subjective feelings of coercion would be relevant to whether there would be an Establishment Clause violation. Even if they were relevant, however, the question would not be whether children feel coerced but whether parents do, because attending the club was a parental decision. Finally, the Court turned the danger that the children might perceive the club as an endorsement of religion on its head, noting that if the Good News Club were excluded, the children might "perceive a hostility toward the religious viewpoint."

The Rehnquist Court has established here an equal facilities doctrine for religion, requiring infrastructure, in terms of physical facilities, to be available for expressive purposes to religious associations if they are made available for expressive purposes to secular associations. The government can create a physical network for facilitating the expressive rights of associations, but it must permit religious associations the ability to hook up to the network.

350. Id. at 2098 (describing the religious nature of the activities at issue in Good News Club).

351. Id.

352. Id.

353. Id. at $2100-01$.

354. Id. at 2101-02.

355. Id. at 2102 .

356. Id. at 2104.

357. Id. at 2106. 
This line of cases also advances a jurisprudence of social discovery because it allows religious ideas on character-building and other social norms to compete with secular ideas and norms. In making the issue of coercion turn on parents rather than children, the Court treats parents as the relevant decision makers and, as elsewhere in current jurisprudence, strengthens the nuclear family as a constitutionally protected association. ${ }^{358}$ In noting that the Good News Club's exclusion could convey a message of religious hostility, the Court suggests that the government must be just as careful to avoid messages of hostility toward religion in general as to avoid messages of endorsement, underscoring the vital importance of religion in American social life noted by Tocqueville. ${ }^{359}$

The Rehnquist Court has followed this Tocquevillian principle by applying similar free speech principles to require that religious associations enjoy the opportunity to apply for funds that the government makes available to secular organizations for expressive purposes. In Rosenberger $v$. Rector and Visitors of the University of Virginia, ${ }^{360}$ the Court held that the University of Virginia could not exclude a student religious magazine from a program under which the university covered the printing costs of qualified student organizations. ${ }^{361}$ Once again, the first doctrinal issue revolved around the limited public forum that the university had created. The Court held that refusing to fund the magazine because of its religious content was impermissible viewpoint discrimination in a limited public forum. ${ }^{362}$ Significantly, the Court also rejected the argument that the university avoided viewpoint discrimination by excluding the whole subject matter of religion and not picking and choosing among different religions. Arguing that such a kind of discrimination would still skew public debate, the Court wrote:

The dissent's assertion that no viewpoint discrimination occurs because the Guidelines discriminate against an entire class of viewpoints reflects an insupportable assumption that all debate is bipolar and that antireligious speech is the only response to religious speech. Our understanding of the complex and multifaceted nature of public discourse has not embraced such a contrived description of the marketplace of ideas....1t is as objectionable to exclude both a theistic and an atheistic perspective on the debate as it is to exclude one, the other, or yet another political, economic, or social viewpoint. ${ }^{363}$

358. It also does so in Troxel v. Granville, 530 U.S. 57 (2000) (striking down law that interfered with parents' authority to determine who could visit their children).

359. For Tocqueville's views on the importance of religion in America, see supra note 315 and accompanying text.

360. 5I5 U.S. 8 I9 (1995).

361. Id. at 845 .

362. Id. at $830-31$.

363. Id. at $831-32$. 
The Court's conclusion in this regard is absolutely crucial if religiously backed norms are to compete with secular norms in the modern world. In the modern world, the separation between viewpoints of different religions on moral and political matters is often minor when compared to the difference between the religious and secular viewpoints. Permitting the government to remove religious discussion from a public forum skews the debate towards the secular view and risks muffling the religious voices that Tocqueville understood as an essential part of the American chorus contributing to American society. ${ }^{364}$

Rosenberger also is significant in that is does not, like Mitchell, merely uphold a decision by the federal government to permit state funds to go to a sectarian institution, but requires that a sectarian institution have access to these funds on equal footing with secular institutions. To be sure, the context is one in which the state has created a limited public forum facilitating the expressive activities or religious associations. Nevertheless, the logic of Rosenberger raises questions of whether the government can use religious expression as a justification for excluding religiously backed schools from funding programs, including vouchers, if it chooses to create such programs. It may seem surprising that the Court protects the rights of religious associations through the Free Speech Clause rather than the Free Exercise Clause, but this shift, like others of the Rehnquist Court, also takes the Constitution back to its historical roots. James Madison, the drafter of the First Amendment, saw free speech and free exercise as two sides of the same coin: property rights that needed special protection against the state. Madison included both free speech and free exercise in his capacious definition of property: "[Property] in its particular application means 'that dominion which one man claims and exercises over the external things of the world, in exclusion of every other individual. ${ }^{\prime \prime 365}$ Paraphrasing the philosopher John Locke he continued:

In its larger and juster meaning, it embraces every thing to which a man may attach a value and have a right; and which leaves to every one else the like advantage.

In the former sense, a man's land, or merchandize, or money is called his property.

In the latter sense, a man has a property in his opmions and the free communication of them.

He has a property of peculiar value in his religious opinions, and in the profession and practice dictated by them.

Government is instituted to protect property of every sort; as well that which lies in the various rights of individuals, as that

364. See supra note 314 and accompanying text.

365. James Madison, Property, NATIONAL GAZETTE (Mar. 27, 1792), reprinted in 14 The PAPERS OF JAMES MADISON 1751-1836, at 266-68 (Robert A. Rutland et al. eds., Univ. Press of Va. 1983). 
which the term particularly expresses. This being the end of government, that alone is a just government, which impartially secures to every man, whatever is his $o w n .{ }^{366}$

The parallel treatment of the Free Exercise Clause and Free Speech Clause as protecting a property right in opinions stems from the Framers' enlightenment view of religion: like secular forms of inquiry, religion helps in the search for truth and good moral norms. ${ }^{367}$ The norms that survive this competitive testing in a world where the government role is limited to preventing their suppression by private or public actors then have some claim to be beneficial. In using free speech to protect religious groups' right to use the state's infrastructure and funding, the Court is restoring the First Amendment to that strand of the enlightenment tradition that is both the Framers' and Tocqueville's. ${ }^{368}$ So long as the government acts neutrally in permitting religious and nonreligious associations to participate in its programs, the government acts constitutionally because, in Madison's words, such a program "leaves to everyone...t the like advantage" in holding his opinions and propagating his views. ${ }^{369}$

\section{The Free Exercise Clause and the Appropriate Neutrality Between the Secular and the Religiously Backed Norms}

One possible counterexample to the Rehnquist Court's creation of space for the flourishing of religious associations might be thought to be Employment Division v. Smith, ${ }^{370}$ where the Court held that the Free Exercise Clause did not exempt religious associations from conforming their conduct to generally applicable laws. ${ }^{371}$ Smith, however, does not represent a departure from a jurisprudence that is solicitous im a neutral manner to the discovery processes of secular and religious associations. First,

366. Id.

367. See Daniel O. Conkle, Religious Purpose, Inerrancy, and the Establishment Clause, 67 IND. L.J. 1, 12 (1991) (suggesting that the Framers viewed religion and secular means of inquiry as complementary rather than antagonistic).

368. This strand is to be contrasted with the enlightenment thought of European continental philosophers like Jean-Jacques Rousseau who were less sympathetic to competition among private norms, particularly in education. For instance, Rousseau expresses his preference for norms generated by the state over those generated by the family in education:

[I] $t$ is a matter of greater importance to the state than to their fathers; for, according to the natural course of things, the father's death often robs him of the final fruits of this education, but the homeland sooner or later feels its effects; the state remains and the family dies out.

Jean Jacques Rousseau, Discourse on Political Economy, reprinted in Rousseav's PolITICAL WRitings 73 (Julia Conaway Bondella trans., Alan Ritter \& Julia Conaway Bondella eds., 1987). Rousseau is not interested in private and religious norms serving as a counterbalance to the state in the context of education. To the contrary, education by the state is necessary to guarantee the primacy of the state: "If [children] are steeped in the laws of the state and the precepts of the general will ... [they will never will] anything but what society wills." Id. at 73-74.

369. See Madison, supra note 365 , at 1751.

370. 494 U.S. 872 (1990).

371. Id. at 879 . 
the Court did not, as some commentators have claimed, ${ }^{372}$ dramatically change the Warren Court jurisprudence about the Free Exercise Clause because that jurisprudence had provided exemptions for religiously motivated conduct from generally applicable laws only in limited circumstances. ${ }^{373}$ Second, Smith may still permit religions to make free exercise claims when the legal exemptions provided to religious conduct are not as generous as those provided to secular conduct with similar consequences. ${ }^{374}$ Finally, the freedom of association rights provided in Dale extend to religious associations and protect their ability to choose their members and beliefs; these elements are necessary for their discovery processes to be independent from the state. ${ }^{375}$ Once again the Court can use the Free Speech Clause of the First Amendment to assure that religion and secular norms compete on a more equal footing.

In Smith, the Court rejected the free exercise claims of the Native Indian Church who wanted to ingest peyote as part of their religious ceremonies and thus be exempted from laws that made taking these drugs illegal. ${ }^{376}$ The Court held that the Free Exercise Clause "does not relieve an individual of the obligation to comply with a valid and neutral law of general applicability." ${ }^{377}$ Regardless of whether the law requires conduct that a religion forbids or prohibits conduct that a religion requires, the obligation remains valid. The Court refused to aceept the argument that the state must show a compelling interest before applying the generally applicable law. First, according to the Court, the compelling interest test would be unworkable. Instead of assuring equal treatment of groups as it does in the equal protection context, applying the compelling interest test would result in a patchwork of exemptions for different religions depending on the balance the courts struck in individual cases. ${ }^{378}$ Second, the test would protect only those who are motivated by religious belief rather than other kinds of belief and thus treat those motivated by religious principles differently from those motivated by secular principles. ${ }^{379}$ This second consideration flows from the neutrality principle that is so proininent in the Rehnquist Court's jurisprudence of the religion clauses.

While Smith was an important case, it did not work a wholesale change in the law because the previous law on the entitlement to religiously motivated conduct exemptions from generally applicable laws was

372. See, e.g., Enwin Chemerinsky, The Rehnquist Court \& Justice: An Oxymoron?, 1 Wash. U.

J. L. \& POL'y 37, 44 (1999) (suggesting that Smith brought an important change in law).

373. See infra notes $380-83$ and accompanying text.

374. See infra notes $384-85$ and accompanying text.

375. See infra notes 386-88 and accompanying text.

376. Employment Div. v. Smith, 494 U.S. 872 (1990).

377. Id. at 879 (quoting United States v. Lee, 455 U.S. 252,263 n.3 (1982)).

378. Id. at 886 .

379. Id. 
incoherent. ${ }^{380} \mathrm{~A}$ few cases in the employment compensation area, most notably Sherbert $v$. Verner, ${ }^{381}$ have held that individuals whose religious beliefs prevented them from engaging in a particular kind of work or working at a particular time could collect unemployment benefits. ${ }^{382}$ But in the vast majority of cases, the Court did not require generally applicable laws to provide exemptions for religiously motivated conduct. ${ }^{383}$

The unemployment cases can be subsumed under a less radical approach to Free Exercise. As the Smith Court observed, what distinguishes the unemployment context is that the government already provides exemptions for a variety of conduct. The Free Exercise Clause can be understood as requiring the state to provide equal treatment of religiously and secularly motivated conduct in terms of exemptions from generally applicable laws. Even some critics of Smith have seized on the validity of such claims to argue that the Free Exercise Clause is alive and well. ${ }^{384}$ One advantage of this kind of free exercise analysis is that it does not give special treatment to religious associations as compared to their secular counterparts, but merely assures that the government does not discriminate against them in regulating their conduct. ${ }^{385}$

380. See Christopher L. Eisgruber \& Lawrence G. Sager, The Vulnerability of Conscience: The Constitutional Basis for Protecting Religious Conduct, 61 U. CHI. L. Rev. 1245, 1246 (1994) (arguing that before Smith, the "[d]octrine governing religious exemptions was in a shambles").

381. 374 U.S. 398 (1963).

382. See also Thomas v. Review Bd. of Ind. Employment Sec. Div., 450 U.S. 707 (1981) (holding that unemployment benefits must be extended to those who refused to work on armaments project).

383. One other case cited as exception by Professors Eisgruber and Sager is Wisconsin v. Yoder, 406 U.S. 205, 207 (1972) (upholding on Free Exercise grounds the right of Amish parents to decline to send children to public schools after eighth grade). Eisgruber \& Sager, supra note 380, at 1246. Understanding the salience of associational rights also allows a reinterpretation of a case decided under the Free Exercise rubric. In Yoder, the Amish did not want to send their children to public schools. Schooling is an expressive activity, and just as individuals should not be forced to admit individuals into their association, at least a noneconomic association, so too they should not be required to associate for expressive purposes with those they would prefer to avoid, absent a compelling interest. The state does not have a compelling interest to force association for education, particularly since the Amish had been educating their children for decades.

384. See Richard F. Duncan, Free Exercise is Dead, Long Live Free Exercise: Smith, Lukumi and the General Applicability Requirement, 3 U. PA. J. CONST. L. 850 (2001). For criticism of this approach to religious exemptions, see Eugene Volokh, Intermediate Questions of Religious Exemptions-A Research Agenda with Test Suites, 21 CARDozo L. Rev. 595 (1999). His altemate approach calls for states to fashion exemptions in a common-law approach. See Eugene Volokh, $A$ Common-Law Model for Religious Exemptions, 46 UCLA L. REv. 1465 (1999). I think an approach that permits exemptions to be adjusted under a regime of jurisdictional competition is also broadly consistent with a jurisprudence of spontaneous order.

385. This kind of analysis of exemptions for religious conduct is very similar to the kind of analysis I have previously advocated for evaluating whether regulation of expressive conduct violates the First Amendment. See McGinnis, Property-Based Vision, supra note 206, at 97-99. In deciding whether government can apply its rules to conduct that is expressive, I suggest that the Court compared the contested regulation with regulatory norms under which the government treats activity with similar effects. Id. at 99 . Thus, the government should not be able to single out burning draft cards as illegal in United States v. O'Brien, 391 U.S. 367 (1968), and yet permit individuals to do other acts that were less expressive and had the same deleterious consequences for smooth administration of the selective 
Finally, the type of free association rights protected by Dale also extend to religious associations. This protection assures that both secular and religious associations have substantial protection against interference with selection of their members. ${ }^{386}$ Such freedom is essential to allow associations to do their work as discovery machines for social norms. It is obviously extremely difficult, if not impossible, for a religious association to produce norms with members whose identity conflict with those norms just as it impossible to produce independent norms if the government dictates tenets of belief. ${ }^{387}$ In contrast, generally applicable rules on the association's conduct, while burdensome in some cases, do not frustrate the mechanism of the discovery process itself. For instance, without peyote the Native American Church remains free to shape the character of its members, but with homosexual priests it is much more difficult for the Catholic Church to say that homosexuality is wrong or even to deliver its message on homosexuality.

Moreover, unlike exemptions for religiously motivated conduct, which must be determined on an ad hoc basis, freedom of association can apply equally to all religious associations. Also, freedom of association, like freedom of speech, applies equally to religious and secular associations, allowing them to fulfill the enlightenment ideal of social competition on an equal footing between religious and secular norms. ${ }^{388}$

Thus, far from being inconsistent with the move to a jurisprudence of social discovery, Smith, when taken in combination with Dale, advances that cause by creating a coherent jurisprudence from a previously fragmented one. ${ }^{389}$ The Rehnquist Court protects the essential elements of discovery machines and in doing so extends the protection equally to

service. Similarly a regulation cannot constitutionally forbid the wearing of a beard for religious reasons if it permits one to be worn for medical reasons when the consequences for uniformity and discipline are similar. See Fraternal Order of Police v. City of Newark, 170 F.3d 359 (3d Cir. 1999), cert. denied, 528 U.S. 817 (1999) (invalidating this regulation). My analysis would also invalidate such regulations as applied to those who wanted to wear beards for reasons of secular expression as well. The Free Speech and Free Exercise Clauses demand that laws treat freedom of expression and religious exercise as interests as weighty as almost any other in the decision to provide exemptions from generally applicable laws. (One exception might be the interest in protecting life.)

386. In the terms of Eisgruber's and Sager's analytic framework, associational rights, whether religious or secular, are protections and not privileges. See Eisgruber \& Sager, supra note 380, at 125052 (describing the difference between the privilege and protection mode of constitutional analysis). Expressive associational rights are protected because they are particularly "vulnerable" to actions by the state. Id. For further discussion of why associational rights are protected, see supra notes 210-12 and accompanying text.

387. For similar analysis in a secular context, see supra note 280.

388. See supra notes 367-68 and accompanying text for full discussion of this point.

389. For these reasons, I think that the Court's decision in City of Boerne v. Flores, 521 U.S. 507 (1997), which refused to overrule Smith, was also consistent with a jurisprudence of spontaneous order. Boerne left it up to a process of jurisdictional competition whether the states were going to give religious associations more than the right of free expression, including expressive association, guaranteed by the Constitution. 
nonreligious and religious groups. This jurisprudence has the added advantage of furnishing the kind of rule that comports with the neutrality requirement between religious and secular institutions that has properly become the touchstone of Establishment Clause jurisprudence. Happily, the Rehnquist Court's jurisprudence helps assure that the Establishment Clause, Free Exercise Clause, and Free Speech Clause work harmoniously rather than conflict with one another. ${ }^{390}$

\section{$\mathrm{V}$}

\section{REINFORCING The JuRy as a MEdiating Institution}

Because punishment in modern society necessarily involves the state and cannot be relegated to private action, criminal law may seem an odd venue for the Court to advance ideals of spontaneous order. But one institution, the jury, can be seen as injecting many of the virtues of spontaneous order into the criminal justice system. It brings to bear local social norms to the issues of law, both supplementing and tempering the legal directives that have been established by more centralized democratic institutions such as legislatures. The jury performs this function better than the judiciary because of its superiority in distilling the diverse opinion of the citizenry.

The Framers saw the jury as a key institution to inject popular sentiment into the legal system. The Constitution deploys juries in both civil and criminal justice, requiring jury trials for criminal prosecutions and preserving the jury trial for suits at common law of substantial value. ${ }^{391}$ The revolutionary generation keenly recalled that the jury had restrained the injustice of the Crown's centralized authority, most notably when a jury had acquitted Peter Zenger for seditious libel brought by the administration of the governor of New York. ${ }^{392}$ The jury thus was originally celebrated as a popular institution that restrained undemocratic authority, at that time the rule of colonial governors appointed by the Crown. But the Framers, who ensured that the law would be made and enforced through democratic mechanisms, retained an important role for the jury in the Republic. In that new democratic context, the jury is distinguished from the legislature and the executive not by its popular nature, but by features that allow the jury better to approximate spontaneous order than those other institutions.

390. See Carl Esbeck, Religion and the First Amendment: Some Causes of Recent Confusion, 42 WM. \& MARY L. REV. 883, 894 (2001) (arguing that neutrality principle is to be commended because it brings the Establishment Clause and the Free Exercise Clause into harmony).

391. See U.S. ConsT. amend. VI ("In all criminal prosecutions the accused shall enjoy the right to a speedy and public trial, by an impartial jury of the State ...."); U.S. CoNST. amend. VII ("In Suits at common law, where the value in controversy shall exceed twenty dollars, the right of trial by jury shall be preserved ....").

392. See Charles Wolfram, The Constitutional History of the Seventh Amendment, 57 MinN. L. REv. 639, 656-66 (1973) (discussing the importance of juries to the revolutionary generation). 
First, the jury is sensitive to the nuances of local values because it is drawn from the local community. ${ }^{393}$ Second, while the jury is a popular, even populist institution, it does not typically face the process defects such as the leverage of special interests and the rational apathy of citizens that beset centralized democracy. In contrast to more centralized democratic institutions that are charged with comprehensive governance, the jury focuses the attention of a set of citizens on a specific purpose and is not as amenable to the pressure of special interest groups.

Because of these virtues, the jury has the opportunity to inject social norms that bubble up from below into the laws that are themselves made in a more top-down manner. As commentators have recognized, juries are called on to provide concrete application to general concepts in criminal and civil law. ${ }^{394}$ The law may allow a defendant to exercise reasonable force in self-defense, but the jury decides through its assessments in specific cases what constitutes reasonable force. The law may punish criminally negligent conduct but the jury decides through its case assessment what constitutes negligence. ${ }^{395}$ In the rarer case of jury nullification, the jury even negates the law by refusing to follow its dictates. Thus, through thousands of decisions each year, the jury infuses local, focused, and popular sentiments into the laws made by more distant institutions less subject to the control of a politically inattentive citizenry.

For similar reasons, Tocqueville himself celebrated juries as a kind of government-assembled civil association. He noted that it placed the "real direction of society in the hands of the governed ... and not in that of the government." 396 He specifically noted that it "contributes powerfully to form the judgment and increase the natural intelligence of a people."397 Thus, in Tocqueville's eyes, the jury had many of the same advantages as civil associations. Like civil associations, juries help form the judgments of a republican people in a decentralized manner. The jury can be seen as injecting many of the virtues of spontaneous order into the criminal justice system. First, a jury is local in that it represents the community. ${ }^{398}$ Second, while the jury is a majoritarian, even populist, institution, ${ }^{399}$ it does not

393. See Akhil Reed Amar, The Bill of Rights as a Constitution, 100 YALE L.J. 1131, 1186 (1991). Professor Amar also called the jury a "mediating institution." Id. at 1186. But in his view, the jury functions as reinforcement of popular sovereignty. In my theory the jury serves as a break on centralized authority, whether exercised bureaucratically or by majorities of the citizenry at large.

394. See Dan M. Kahan \& Martha C. Nussbaum, Two Conceptions of Emotion in Criminal Law, 96 CoLum. L. REv. 269, 349 (1996) (discussing the manner in which juries make the law responsive to shifting social norms).

395. Cf. Benmanin N. Zipursky, Legal Malpractice and the Structure of Negligence Law, 67 FORDHAM L. REv. 649, 680 (1998) (suggesting that social norms fill in the coneept of negligence in tort law).

396. 1 DEMOCRACY IN AMERICA, supra note 21, at 282.

397. Id. at 285.

398. See Amar, supra note 393, at 1186.

399. Id. at $1183-85$. 
typically face the process defects such as the leverage of special interests and the rational apathy of citizens that beset centralized democracy. The jury, in contrast to elected representatives and judges, directs a set of citizens' attention on a specific goal and is not subject to special interest group pressure. Like civil associations, the jury even has an educative function, ${ }^{400}$ making it easier for citizens ignorant of the law to understand their rights.

Thus, one would expect a court that was reviving a Tocquevillian polity to be moving toward a jurisprudence that would enlarge the role of criminal juries. While it might seem inconsistent with federalism and respect for legislative supremacy for a federal court to supervise the division between judge and jury set by state and federal legislatures, it would be doing so in the interest of passing decision making to a more responsive unit. In this sense, the Rehnquist Court's decision to set aside restrictions on the jury's role is very similar to setting aside government restrictions on the associational rights of civil organizations, both secular and religious. The Court wants to protect the autonomy of more decentralized institutions from the usurpations of more centralized power.

Accordingly, it is not surprising that in one of the most important criminal law decisions last term, Apprendi v. New Jersey, ${ }^{401}$ the Rehnquist Court provided a greater scope for spontaneous order in criminal law by expanding the role of the juries at the expense of judges. ${ }^{402}$ That case concerned a New Jersey statute that directed a judge to provide an enhanced sentence for a crime if the judge found by a preponderance of the evidence that racial hatred notivated the crime. ${ }^{403}$ Justice Stevens held that the Fifth Amendment's Due Process Clause and the Sixth Amendment's notice and jury trial gnarantees mandate that, except for a prior conviction, all facts that increase the maximum penalty for a crime must be charged in an indictment, submitted to a jury, and proved beyond a reasonable doubt. ${ }^{404}$ Justice Stevens responded to New Jersey's argument that the inquiry into motivation was not a traditional element of the crime, by saying that for these purposes an element must be defined functionally as any factor that could increase the punishment for the crime. On this view, the degree of culpability that the legislature selects powerfully affects the liberty interests the Fifth and Sixth Amendment guarantees protect. ${ }^{405}$

400. Id. at $1186-87$.

401. 530 U.S. $466(2000)$.

402. Id.

403. Id. 471 .

404. Id. at 490. Justice Stevens argued that these protections derive from the common law that limited judges' discretion to penalties prescribed by legislature for offenses all of whose elements were determined by a jury. Id. at 494-97.

405. Id. at 494 . 
As Justice O'Connor's dissent suggests, ${ }^{406}$ further litigation will be necessary to clarify the Apprendi rule. But whatever the ultimate scope of the Apprendi rule, it at least symbolically empowers juries. After Apprendi no one can be sentenced to a term of years longer than the maximum term for the offense for which a jury finds him guilty. ${ }^{407}$ Apprendi rejected a structure by which the state (in the role of the judge) can make determinations creating additional legal liability in favor of giving those decisions to the jury.

Thus, Apprendi is consistent with a new jurisprudence favoring decentralized order. Indeed, a debate in Apprendi between Justice Scalia and Justice Breyer was the most explicit discussion in recent memory of the division between a jurisprudence that is friendly to a top-down version of social ordering and a jurisprudence of decentralization. Justice Breyer's dissent suggests that a judge's control over factual determinations, triggering sentencing decisions, will lead to greater fairness because judges will better preserve equality of sentencing across cases if guided by statutes or sentencing guidelines. ${ }^{408}$ Breyer's opinion represents a powerful statement of the conviction that centralized processes are necessary to handle the sentencing process's administrative complexity. ${ }^{409}$ On this view, there are simply too many factors for juries to consider to fix a sentence that provides both deterrence and equity. ${ }^{410}$

In his concurrence, Justice Scalia expressly responds to Justice Breyer. He argues that the Constitution's overriding concern is to constrain judges (whom he describes as bureaucrats) from usurping essential factual determinations about criminal guilt and consequent legal liability. ${ }^{411} \mathrm{His}$

406. Justice $O^{\prime}$ Connor dissented, arguing first that the Court had previously permitted the legislature substantial discretion in defining elements of a crime that require these constitutional safeguards. Id. at 523 (O'Connor, J., dissenting). Second, Justice $\mathrm{O}^{\prime}$ Connor complained that under a narrow interpretation the Court's rule would still allow judges to make determinations affecting sentences so long as they were within a statutorily prescribed range. Id. at 540-41. In Justice O'Connor's view, this would still leave defendants subject to the mercy of judicial decision making, making Apprendi a formalistic nuisance. Under a broader interpretation, Apprendi would require that the jury determine any factor (even with a statutorily prescribed range) that made a real difference to the sentence. See id. at 543-44. Justice O'Connor claimed that this would gravely undermine the Federal Sentencing Guidelines in which judges make numerous determinations that affect the length of a sentence. Id. at 544.

407. See id. at 490 .

408. Id. at 555-56 (Breyer, J., dissenting). At one point in his opinion Justice Breyer disavows an interest in "procedural fairness" to suggest his focus is rather "procedural compromise." Id. at 555 . But at other times his opinion is clearly concerned with fairness. Id. at 559 (stating that his concurrence explained "why, in respect to sentencing systems, proportionality, uniformity, and administrability are all aspects of that basic 'fairness' the Constitution demands").

409. For academic support for the Breyer view, see Robert F. Wright, Sentencers, Bureaucrats, and the Administrative Perspective on the Federal Sentencing Commission, 79 CALIF. L. REv. 1, 7-23 (1991).

410. Apprendi, 530 U.S. at 557.

411. Id. at 498 (Scalia, J., concurring). 
opinion represents the belief that freedom is best protected in the most decentralized form of order possible, in this case from jury decisions by twelve citizens chosen at random. For Justice Scalia, the contribution that the more decentralized order makes to freedom should be preserved even at risk to some ideal patterns of equality across cases. ${ }^{412}$ His opinion represents one of the most self-conscious statements of the Court's growing preference for creating order from below.

To be sure, the Rehnquist Court's movement toward empowering juries is not as pronounced as its movement toward a Tocquevillian America in other areas because Apprendi does not represent the culmination of a long doctrinal trend in case law. In Jones $v$. United States, decided just a year earlier, the Court had presaged its position in Apprendi by decliming to read a statute as creating an offense permitting three different degrees of punishments depending on determinations by a judge, rather than creating three separate offenses to be determined by a jury, because it had constitutional doubts about judicial enhancements of sentences. ${ }^{413}$ In Almendarez-Torres $v$. United States, decided two years before, the Court, however, was willing to permit the judge to enhance a sentence based on a previous conviction that was not even inentioned in the indictinent of the accused. ${ }^{414}$ While Apprendi distinguished Almendarez-Torres on the basis that the enhancement concerned recidivism, ${ }^{415}$ a traditional factor for judges to consider in sentencing, and that the constitutional claim revolved around the Fifth Amendment right of notice rather than Sixth Amendment

412. My primary discussion here is limited to the criminal jury. But two Rehnquist Court cases on the civil jury might be thought to cut against the movement to revive the jury as a mediating institution more generally. In BMW of North America v. Gore, 517 U.S. 559 (1996), a five-member majority used the Due Process Clause to put limitations on punitive damages. The opinion of the Court, however, is less a discussion of the proper role for the jury (as the Seventh Amendment has not been incorporated against the states) than a defense of the economic integrity of the continental market for goods and services against states that interfere with that market through excessive jury awards. Id. at 572-74. As noted above, supra notes 266-68 and accompanying text, the Rehnquist Court is sustaining decentralized discovery machines for noneconomic norms but tolerates more centralized setting of economic norms.

Some also have thought the test of Daubert v. Merrill Dow Pharmaceuticals, Inc., 509 U.S. 579 (1993), limits the role of juries in evaluating scientific evidence. See Bert W. Rein, The Role of the Jury in the Evaluation of Scientific Evidence, 9 KAN. J.L. \& PUB. PoL'Y 28 (1999). Daubert, however, concerns scientific norms that can be rooted in objective evidence, not in social norms of right and wrong that depend, at least to some degree, on the preferences of citizens. Moreover, in any event, Daubert's holding is not a construction of the Constitution, but of Rule 702 of the Federal Rules of Evidence, and thus does not much bear on the coherence of the Court's constitutional jurisprudence. And some other commentators have thought that Daubert does not diminish the role of the jury because even before Daubert federal judges had served as gatekeepers for the decision whether to admit scientific evidence. See Jean Macchiaroli Eggen, Toxic Torts, Causation and Scientific Evidence After Daubert, 55 U. PIrT. L. Rev. 889 (1994).

413. 526 U.S. 227, 239-52 (1999).

414. 523 U.S. 224, 247 (1998).

415. Apprendi, 530 U.S. at 490 . 
right to jury, Almendarez-Torres seems to take a much less aggressive stance toward empowering juries than Apprendi.

Particularly in light of Apprendi's shallow roots in the Rehnquist Court's previous jurisprudence, it leaves many questions that only future decisions will answer. The most important is whether the holding will be limited to requiring juries to make decisions about elements of a crime that increase a sentence beyond the maximum otherwise prescribed sentence or whether it will also require juries to make decisions about elements that determine a sentence within a prescribed range. The holding of Apprendi encompasses only the former more limited proposition, but the concurrence by Justice Thomas and perhaps the inner logic of the decision would embrace the broader rule of law. Justice Thomas argued that the history of the jury at the common law suggested that all facts on which a legislature chooses to base a sentence are elements that must be proven. ${ }^{416}$ Moreover, what commentators have called the "central rationale" of Apprendi-that "it is wrong to convict a person of one crime and impose punishment for another"-would apply to legislatively established factors that raise the sentence even with a prescribed minimum. ${ }^{417}$ For instance, assume that a set of sentencing guidelines permits a sentence to be raised based on previous bad conduct, such as assaults, even though those assaults have never been charged as a crime. Such a procedure still circumvents the jury's rule in assessing whether the conduct on which the sentence rests was indeed a crime. Because the assault may involve such questions as the reasonableness of the use of force it also implicates the jury's function in shaping social norms.

If the Supreme Court ultimately refuses to adopt the inore expansive definition of Apprendi, there is the risk that legislatures can simply circumvent the decision by raising the maximum sentences on crimes and permitting judges to lower the sentence if some element is not found. ${ }^{418}$ The Apprendi Court seemed to recognize this possibility and suggested that such schemes would be subject to close constitutional review. ${ }^{419}$ Commentators are already beginning to consider substantive rules that prevent legislatures from removing some elements relevant to sentencing from the

416. Id. at 502 (Thomas, J., concurring).

417. Erwin Chemerinsky, Law Enforccment and Criminal Law Decisions, 28 Pepp. L. Rev. 517, $522(2001)$.

418. See Benjamin N. Priester, Constitutional Formalism and the Meaning of Apprendi v. New Jersey, 38 AM. Crim. L. Rev. 281, 302 (2001) (suggesting that the formal rule of Apprendi can easily be undermined by legislative changes that would allow judges to adjust sentences downwards rather than upwards).

419. Apprendi, 530 U.S. at 490 n.16 ("In all events, if such an extensive revision of the State's entire criminal code were enacted for the purpose the dissent suggests ... we would be required to question whether the revision was constitutional under this Court's prior decisions."). 
jury. ${ }^{420}$ For instance, if the legislature redefines an offense to include both conduct that was a misdemeanor and more aggravated conduct that was a felony and permits a judge through lowering a sentence maximum to make the distinction between the two, the legislature may be invading the historic province of the jury. ${ }^{421}$ Whatever route the Court chooses to make Apprendi functionally as well as symbolically effective, it should heed its own early express concern that some modern sentencing schemes would "shrink" the jury's role from the "significance" usually "carried by determimations of guilt" to that of "low-level gatekeeping."422 Low-level gatekeeping does not provide a sufficient role for the jury to fulfill its important function in shapimg social norins. ${ }^{423}$

VI

The Framework of Fundamental Rights Jurisprudence and the CONSTRuCtron of a CONSTrTutron OF SPONTANEOUS ORDER

John Hart Ely was unable to reconcile the creation of unenumerated fundamental rights, like abortion, with the Warren Court's democracy remforcing jurisprudence. ${ }^{424}$ Similarly, fundamental rights jurisprudence is inconsistent with the emerging jurisprudence of spontaneous order and decentralization. ${ }^{425}$ As a matter of theory, fundamental rights jurisprudence can raise inconsistencies with a jurisprudence of spontaneous order in two ways. First, the rights themselves may not be conducive to spontaneous ordering. Second, their method of fornulation, through judicial fabrication, appears to be the reverse of spontaneous order.

On the first axis, many fundamental rights clearly differ in structure from rights of free association and the rights of state autonomy because the fundamental rights announced are often simply social norms and not discovery machines for finding social nonns. For instance, unlike the right of association, a right to abortion does not empower a discovery machine that

420. See Nancy J. King \& Susan R. Klein, Essential Elements, 54 VAND. L. Rev. 1467, 1535 (2001) (proposing multifactor test to prevent legislatures from circumventing Apprendi); see also Kyron Huigens, Solving the Apprendi Puzzle, 90 GEo. L.J. (forthcoming 2002) (suggesting that the Supreme Court embrace substantive theory of criminal law to limit legislatures' ability to take substantive issues from jury determination).

421. King, supra note 420 , at 1537-38.

422. Jones v. United States, 526 U.S. 227, 244 (1999).

423. Even if the Court ultimately permits judges to make sentencing decisions within limits set by a jury it may still be creating a less bureaucratic order than that which exists under sentencing guidelines. Under sentencing guidelines, prosecutors and probation officers exercise substantive discretion as to what sentence an offender should receive. See KATE STITH \& Jose A. Cabranes, Fear OF JUDGING, 85-95, 139-42 (1998). Thus current application of sentencing guidelines reflects a quimtessentially bureaucratic order.

424. See John Hart Ely, The Wages of Crying Wolf: A Comment on Roe v. Wade, 82 YALE L.J. 920 (1973) (critiquing fundamental rights jurisprudence as value imposition without warrant in the Constitution).

425. 530 U.S. $57(2000)$. 
helps us find social norms. On the second axis, that of process, fundamental rights are themselves created through a process that reflects top-down ordering rather than spontaneous order. Certainly if fundamental rights jurisprudence is constituted by the abstract reasoning of the Supreme Court on what rights are particularly important, ${ }^{426}$ it is the most centralized form of centralized ordering. Nime judges living in Washington, D.C., an artificial city whose principal business is minding other people's business, generate such decisions. ${ }^{427}$ Moreover, federal judges generally, and Supreme Court Justices particularly, are quite isolated from the ebb and flow of civil associations and enterprises throughout the nation. ${ }^{428}$

Of course, while many scholars have agreed that the Justices' values dictate a process that creates the fundamental rights jurisprudence, ${ }^{429}$ the Justices themselves have not conceded the correctness of this view. Only two current Justices, Justice Scalia and Justice Souter, have offered substantial theories of fundamental rights that attempt to limit the reservoir of judicial discretion. Justice Souter would use a common law tradition where the Court looks to previous precedents to discern by analogy whether similar fundamental interests in the modern era should be similarly protected. ${ }^{430}$ But even if one accepts analogical reasoning as substantial discipline on discretion (a claim that is open to serious question), reliance on precedent simply pushes the discretionary power back to past Justices. The Supreme Court in the past was no more capable than it is now of discovering the right social norms because, as discussed above, it is part of centralized ordering and not subject to competition. ${ }^{431}$ Justice Scalia, who would substantially shrink the scope of fundamental rights jurisprudence, has suggested looking back to tradition for the few fundamental rights that he would uphold. ${ }^{432}$ But traditions have neither

426. For criticism of fundamental rights as abstract reasoning, see ELY, supra note 4, at 56-60.

427. See John O. McGinnis, Justice Without Justices, 16 Const. Comm. 541, 543 (1999) (discussing factors that make Supreme Court Justices remote from the body politic).

428. Id.

429. See, e.g., Michael J. Klarman, The Puzzling Resistance to Political Process Theory, 77 VA. L. REv. 747, 771 (1991) (suggesting that is not difficult to show that, however structured, fundamental rights jurisprudence appears to grant substantial discretion to judges).

430. Justice Souter has set out his views of how to derive fundamental rights in Washington $v$. Glucksberg, 521 U.S. 702, 765 (1997) (Souter, J., concurring) (arguimg in favor of common law tradition of fundamental rights derivation as exemplified by Justice Harlan in Poe v. Ullman, 367 U.S. 497, 522 (1961) (Harlan, J., dissenting)).

431. See supra notes 427-28 and accompanying text. See also A.C. Pritchard \& Todd J. Zywicki, Finding the Constitution: An Economic Analysis of Tradition's Role in Constitutional Interpretation, 77 N.C. L. Rev. 409, $489-93$ (arguing that the Supreme Court is not a common law court and therefore that Justice Souter's defense of fundamental rights jurisprudence fails).

432. See Michael H. v. Gerald D., 491 U.S. 110 (1989) (Scalia, J., concurring) (accepting that fundamental rights might be derived from interests "traditionally protected by our society"); see generally Pritchard \& Zywicki, supra note 431, at 418-26 (discussing Justice Scalia's "majoritarian theory of tradition"). 
clear boundaries nor clear definitions, leaving much room for judicial manipulation, and traditions organically change, while fundamental rights precedent becomes positive law. ${ }^{433}$ Thus, whatever its chosen form, fundamental rights jurisprudence as a whole does not offer the advantages that the competitive process of spontaneous order provides.

One response to this process objection to fundamental rights jurisprudence might be that the principles of federalism and the First Amendment enforced by the judiciary are also the product of a top-down process, that is the Framing itself as well as the subsequent amendments to the Constitution. ${ }^{434}$ First, as Professor Adam Pritchard and Todd Zwyicki suggest, the Framers "chose to imitate" nrany important concepts like the separation of powers and individual rights that had been generated by the constitutional struggles in Britain and thus that were themselves the product of a decentralized process. For instance, federalism arose from the structure of the coloines, which were theniselves the divisions of the New World that monarchs in Great Britain had arranged with various entrepreneurs, thus showing that federalism has a basis in the spontaneous order of commerce. ${ }^{435}$ The principles laid down in the Constitution come from a process that is far more consistent with the goals of spontaneous order than fundainental rights jurisprudence. ${ }^{436}$

Second, both the Framing and amendment process are structured to avoid many of the defects of processes of centralized order. The Framing required and the amendment process still requires enactments to surmount a double supermajoritarian process. ${ }^{437}$ This process requires a greater consensus, making it harder for interest groups to obtain their

433. See John O. McGinnis, In Praise of the Efficiency of Decentralized Traditions and Their Preconditions, 77 N.C. L. REv. 523, 532 (1999) (suggesting that judges will deploy a great deal of discretion in choosing which traditions to follow); see also Pritchard \& Zywicki, supra note 431, at 473-82 (criticizing Scalia's reliance on legislative majorities to find traditions).

434. Hayek himself saw the Framing as a potential example of successful conscious design and was bothered by its implication for his theory's endorsement of structures that arise from spontaneous design alone. See F.A. HAYEK, THE CONSTITUTION OF LIBERTY 183 (1960).

435. Id.

436. One objection to the distinction made here is that fundamental rights jurisprudence can be derived from the Constitution in just as legitimate a way as First Amendment jurisprudence or the limitations of federalism. These interpretative claims are beyond the scope of this Article. Suffice it to say that I believe that the views of the Fist Amendment and federalism being revived by the Supreme Court are rooted in the original constitution in a way that fundamental rights jurisprudence is not. For a discussion of the original meaning of the First Amendment that supports the results reached in the current term, see McGinnis, Property-Based Vision, supra note 206. For a discussion of the original meaning of the commerce power, see Epstein, supra note 63. For discussion of the reasons that substantive due process cannot be rooted in the text of the Constitution, see John Harrison, Substantive Due Process and the Constitutional Text, 83 VA. L. REv. 493 (1997).

437. Article VII of the Constitution required ratification by mine states to establish the Constitution, and the Constitutional Convention was also called by a supermajority of states. This point is discussed at length im McGinnis \& Rappaport, Our Supermajoritarian Constitution, supra note 301. Similarly, Article V requires two-thirds of each house or two-thirds of state legislatures to propose an amendment and three quarters of the states to ratify it through either legislatures or conventions. 
enactments. ${ }^{438}$ Moreover, both the Framing and the amendment process elicit great public attention and input, thus also making for higher quality provisions. ${ }^{439}$ Finally, because constitutional enactments are long lasting, citizens pass them under a "gauzier" veil of ignorance, also making them more likely to be in the public interest. ${ }^{440}$ Thus, the supermajoritarian process for establishing and amending our Constitution achieves many of the same goals as the process of spontaneous order, which also reduces the problems of undue leverage by interests, including elites, and the rational ignorance of citizens. The provisions included in our Constitution therefore should be much closer to those chosen through a process of spontaneous order. ${ }^{441}$ Supermajoritarianism can, in some circumstances, serve as a substitute for spontaneous order when spontaneous order is not possible. ${ }^{442}$

Consistent with a jurisprudence of spontaneous order, the Court appears to be cutting back on announcing fundamental rights. Most notable is its decision in Washington v. Glucksberg, ${ }^{443}$ not only because the Court unanimously declined to announce a constitutional right to assisted suicide, but because the majority opinion offered an analysis of fundamental rights that suggested that there would be few such announcements in the future. In Glucksberg, physicians in Washington challenged Washington's ban on assisted suicide, saying that they would aid terminally ill patients in ending their lives if not prevented by the ban. ${ }^{444}$ Rejecting their petition for the majority of the Court, Chief Justice Rehnquist began by noting that there was no tradition of legally assisted suicide in the Anglo-American world. ${ }^{445}$

438. See John R. Vile, Constitutional Change in the United States: A Comparative STUdY OF THE ROLE OF CONSTITUTIONAL AMENDMENTS, JUdiCIAL INTERPRETATIONS, AND LEGISLATIVE AND EXECUTIVE ACTIONS 95-96 (1994) (suggesting that the obstacles in the constitutional amendments process discourage interest groups). For further discussion of the effects of the supermajoritarian character of the amendment process, see John O. McGinnis \& Michael B. Rappaport, Still a Solution: In Further Support of Spending Supermajority Rules, 40 WM. \& MARY L. REv. 527, 552-53 (1999).

439. Michael Rappaport and I discuss the importance of the supermajoritarian nature of the process for establishing and amending the Constitution at much greater length in McGinnis \& Rappaport, Our Supermajoritarian Constitution, supra note 301.

440. See McGinnis \& Rappaport, Our Supermajoritarian Constitution, supra note 301; McGinnis \& Rappaport, Still a Solution, supra note 438, at 552.

441. In other words, as the consensus required of a social norm enacted through a centralized process approaches unanimity, the norms selected will approximate a norm that would emerge from jurisdictional competition. Jurisdictional competition, however, retains advantages over a structure that requires a strong national consensus when more than one norm is appropriate because it permits different norms that respond to the preferences of individuals who live in different jurisdictions or participate in different associations.

442. Much of spontaneous order depends on a legal framework that itself cannot be spontaneously generated or at least not quickly enough to found a republic. For instance, jurisdictional competition among the states depends on a national guarantee of freedom of movement of capital. See McGinnis, supra note 433 , at 526 .

443. 521 U.S. 702 (1997).

444. Id. at 707 .

445. Id. at 719 . 
In fact, the common law tradition continued by modern statutes had punished assistance for suicide. ${ }^{446}$

After claiming that the Court had been reluctant to expand fundamental rights under the theory of substantive due process, the Chief Justice formulated a quite restrictive test for finding further fundamental rights. ${ }^{47}$ Fundamental rights are only those "deeply rooted in the Nation's history and tradition." described so as to assess whether it has these deep roots. ${ }^{449}$ It is not enough to say that assisted suicide is simply the right to die. Only when it is formulated more narrowly, can one assess whether it is protected by the nation's traditions.

If Roe $v$. Wade $e^{450}$ had rigorously applied this test, it would not have announced a right to abortion. The right to abortion would have been described precisely as such and there was no right to abortion so described deeply ingrained in the nation's traditions. States had generally punished abortions, even abortions early in the term of pregnancy, beginning in the mid-nineteenth century. ${ }^{451}$ The Chief Justice's new test, if taken seriously, suggests that the Court is largely closing down its authority to mint new fundamental rights because legislators are almost by definition unlikely to trench on traditions that are so deeply rooted that they can form a predicate for fundamental rights.

It is true that in Stenberg v. Carhart, ${ }^{452}$ the Court struck down the partial-birth abortion law under fundamental right jurisprudence imitiated in Roe v. Wade. But this decision simply articulates the contours of the fundamental right to an abortion previously declared. ${ }^{453}$ Moreover, it is also true that in Troxel v. Granville, ${ }^{454}$ the Supreme Court held that a Washington statute permitting state courts to require visitations of interested persons, mcluding relatives, to children, violated the substantive due process rights of citizens. Like Stenberg, however, Troxel depends on a

446. Id. at 711-19.

447. Id. at $720-21$.

448. Id. at 421 (quoting Moore v, City of East Cleveland, 431 U.S. 494, 502 (1976)).

449. Id. at 721 .

450. 410 U.S. 113 (1973).

451. See David J. Langum, A Personal Voyage of Exploration Through the Literature of Abortion History, $25 \mathrm{LAW} \&$ Soc. INQUIRY 693, 696 (2000) (discussing history of state antiabortion laws).

452. 530 U.S. $914(2000)$.

453. Stenberg's doctrinal significance may be to show that Planned Parenthood v. Casey, 505 U.S. 833 (1992), changed the law of abortion less than commonly thought. Justice Kennedy, who joined in the decisive plurality opinion in Casey, dissented in Stenberg because he believed that the Stenberg majority did not give the proper deference to state interests, such as erecting a barrier to infanticide, recognized in Casey. See Stenberg, 530 U.S. at 960 (Kennedy, J., dissenting).

454. 530 U.S. 57 (2000). 
fundamental right already declared, in this case the right of parents to bring up their children. ${ }^{455}$

Moreover, as a substantive matter-what I have called the first axis on which fundamental rights can be criticized from the standpoint of spontaneous order-Troxel is less troubling than Stenberg. Unlike a right to abortion, the right of parents to control the visitors to their children could be understood as contributing to spontaneous order. ${ }^{456}$ Families are associations and a parents' ability to determine who will visit their children may contribute to expressive norms about the character and behavior of potential visitors. ${ }^{457}$

The Court's adherence to precedent in fundamental rights jurisprudence, however, may suggest a dilemma at the heart of a jurisprudence favoring decentralization and spontaneous order. Any constitutive structure of spontaneous order needs protection from the more centralized forms of order with which it necessarily coexists. Interest and ideological groups, in particular, will exploit their differential power in democratic structures to expand centralized forms of order. ${ }^{458}$ Thus, for instance, the doctrine of enumerated powers on which federalism rests has been under constant attack, as interest groups seek to centralize political power and avoid jurisdictional competition. ${ }^{459}$

In our Constitution, therefore, much of spontaneous order depends on the Supreme Court's ability, itself a centralized government institution, to sustain the conditions for local and private processes to work. The paradox is not fatal to the coherence of a jurisprudence of decentralization and spontaneous order, so long as the Court's role is defined as protecting the conditions for that order. Indeed, exactly the same surface paradox is present in John Hart Ely's defense of the Warren Court: a nondemocratic

455. This fundamental right was recognized as early as Pierce v. Society of the Sisters of the Holy Names of Jesus and Mary, 268 U.S. 510 (1925), which provided a familial right to send children to religious school.

456. Professor Paulsen nicely links Troxel to Dale (the Boy Scouts case) in protecting liberty of association, although he too criticizes the substantive due process reasoning. See Paulsen, supra note 212 , at $1943-45$.

457. Professor Paulsen suggests that other reasoning, besides that of fundamental rights, can support this decision. Id. As Professor Paulsen correctly observes, the question is whose rights of association are at issue. Id. at 1945. I am not as convinced, as Professor Paulsen is, that the common law decision to give parents the right to determine associations of their children means that the such a determination is enshrined in the Constitution. The world of the family has changed since 1787, and, absent evidence that the Framers wanted to enshrine the common law baseline, the Constitution should not bar states from establishing another framework, particularly in order to vindicate the rights of other family members for whom the common law may well have worked better in that era. See also Stephen G. Gilles, Parental (and Grandparental) Rights After Troxel v. Granville, 9 SUP. CT. ECoN. REv. 169 (2001) (defendimg common law rule which gave control over visitations to parents).

458. See John O. McGinnis, The Original Constitution and Its Decline: A Public Choice Perspective, 21 HARV. J.L. \& Pub. PoL'y 195, 208 (1997) (explaining why a good constitution has a natural tendency to decline).

459. Id. at 205-06. 
institution was defined by its democracy-reinforcing role. ${ }^{460}$ But from this perspective the Supreme Court is in an uneasy position as an institution part of, and in some measure dependent on, the national political process but defined by its role in limiting the power of that process. This somewhat difficult position may be the reason the Court needs to preserve its political prestige both by moving incrementally and by not readily admitting error. In this way, the Court avoids open confrontation and possible discrediting by the interest and ideological forces that it must constrain. Thus, the Court may succeed in taking the country back to a jurisprudence of spontaneous order and decentralization by preserving, for a time, the principal landmarks of a previous era of top-down social ordering.

\section{CONCLUSION}

The Rehnquist Court is reinvigorating a jurisprudence favoring spontaneous order and decentralization across a broad range of doctrine. Whether consciously or not, this jurisprudence reflects a turn away from centralized democracy that previous Courts' jurisprudence was designed to perfect. Within the confines of precedent, and in accordance with original constitutional principles, the Court is expanding the autonomy of the states at the expense of federal power, the autonomy of private associations at the expense of the state power, and the primacy of juries at the expense of judges. At the moment, the Rehnquist Court's jurisprudence is not a thoroughgoing states' rights jurisprudence that would revive the states' conclusive authority over econoinic regulation as well as noneconomic regulation. Nor is it a thoroughgomg libertarian jurisprudence that would liberate economic actors from much state regulation.

Instead, the constitutive structures shaped by the Court concentrate on reviving both states and noneconomic associations so that social norns will arise through competition rather than be imposed through centralized bureaucracy or democracy. This jurisprudence can be understood as an attempt to revive limited government and create the space for the civil society that Tocqueville celebrated insofar as these goals are not foreclosed by the modern welfare state. Whether this jurisprudence will prove stable depends on whether the spontaneous order it protects will ratify or undermine the distinctions, such as those between noneconomic and economic activity, on which it now rests. In this sense, the Court's emerging jurisprudence will inevitably become part of the spontaneous order it helps sustain. 
